UNIVERSIDADE DE SÃO PAULO

ESCOLA DE ENFERMAGEM

THAÍS TREVISAN TEIXEIRA

COLA ADESIVA CIRÚRGICA NO REPARO DE LACERAÇÕES PERINEAIS DE PRIMEIRO GRAU NO PARTO NORMAL: ESTUDO PILOTO ALEATORIZADO CONTROLADO

São Paulo

2018 
THAÍS TREVISAN TEIXEIRA

\section{COLA ADESIVA CIRÚRGICA NO REPARO DE LACERAÇÕES PERINEAIS DE PRIMEIRO GRAU NO PARTO NORMAL: ESTUDO PILOTO ALEATORIZADO CONTROLADO}

Versão corrigida da Dissertação apresentada ao Programa de Pós-Graduação em Enfermagem da Escola de Enfermagem da Universidade de São Paulo para obtenção do título de Mestra em Ciências

Área de concentração: Cuidado em Saúde

Orientadora: Prof. ${ }^{a}$ Dr. ${ }^{a}$ Maria Luiza Gonzalez Riesco

\section{VERSÃO CORRIGIDA}

A versão original encontra-se disponível na Biblioteca da Escola de Enfermagem da Universidade de São Paulo e na Biblioteca Digital de Teses e Dissertações da Universidade de São Paulo

São Paulo 
AUTORIZO A REPRODUÇÃO E DIVULGAÇÃO TOTAL OU PARCIAL DESTE TRABALHO, POR QUALQUER MEIO CONVENCIONAL OU ELETRÔNICO, PARA FINS DE ESTUDO E PESQUISA, DESDE QUE CITADA A FONTE.

Assinatura:

Data:

\section{Catalogação na Publicação (CIP) \\ Biblioteca "Wanda de Aguiar Horta" \\ Escola de Enfermagem da Universidade de São Paulo}

Teixeira, Thaís Trevisan

Cola adesiva cirúrgica no reparo de lacerações perineais de primeiro grau no parto normal: estudo piloto aleatorizado controlado / Thaís Trevisan Teixeira. São Paulo, 2018.

$121 \mathrm{p}$.

Dissertação (Mestrado) - Escola de Enfermagem da Universidade de São Paulo.

Orientadora: Prof. ${ }^{a}$ Dr. ${ }^{a}$ Maria Luiza Gonzalez Riesco

Área de concentração: Cuidado em Saúde

1. Parto. 2. Períneo. 3. Enfermagem obstétrica. I. Título.

Ficha catalográfica elaborada por Fabiana Gulin Longhi Palacio (CRB-8: 7257) 
Nome: Thaís Trevisan Teixeira

Título: Cola adesiva cirúrgica no reparo de lacerações perineais de primeiro grau no parto normal: estudo piloto aleatorizado controlado

Dissertação apresentada ao Programa de Pós-Graduação em Enfermagem da Escola de Enfermagem da Universidade de São Paulo para obtenção do título de Mestra em Ciências

Aprovado em:

\section{Banca Examinadora}

Orientadora: Profa. Dra. Maria Luiza Gonzalez Riesco

Instituição:

Assinatura:

Prof. Dr.

Instituição:

Julgamento:

Assinatura:

Prof. Dr.

Instituição:

Julgamento:

Assinatura:

Prof. Dr.

Instituição:

Julgamento:

Assinatura: 


\section{DEDICATÓRIA}

Aos meus pais, que sempre me apoiaram com muito amor. 


\section{AGRADECIMENTOS}

À minha querida orientadora, $\operatorname{Prof}^{\mathrm{a}} \operatorname{Dr}^{\mathrm{a}}$ Maria Luiza Gonzalez Riesco, por toda competência, empatia, respeito e carinho com que me orientou neste trabalho e ao seu esposo Luciano, que gentilmente me acolheram em sua casa para que pudéssemos finalizar a pesquisa;

À professora Adriana Caroci que contribuiu com a idealização desta dissertação, coleta de dados e desenvolvimento do trabalho, além de toda gentileza de me acolher em sua casa para o desenvolvimento do mesmo;

Às professoras Angela Ochiai, Sônia Maria Junqueira, Maria Alice Tsunechiro, Amélia Fumiko, Vera Lucia Conceição e Ana Luiza Vilela Borges pela importante contribuição com o desenvolvimento deste trabalho;

À Nathalie Leister pela riquíssima contribuição e incentivo no desenvolvimento deste trabalho e vida acadêmica;

Às minhas queridas amigas Gisele, Ligya, Fernanda e Sayuri que tornaram os dias na pósgraduação mais floridos e alegres;

À Percela e Wesllany que muito contribuíram durante as disciplinas e durante a minha coleta de dados, meus sinceros agradecimentos;

Ao Bernardo, que contribuiu com a análise estatística deste trabalho;

À Midy Comercial Ltda pelo fornecimento das colas adesivas, em especial à Hélida, farmacêutica desta empresa, que gentilmente me forneceu todas as informações necessárias para a utilização das colas;

A toda equipe da EEUSP pelo apoio durante minha trajetória no mestrado, em especial à equipe da biblioteca que contribuiu muito com os excelentes cursos ministrados;

Ao CNPq que concedeu a bolsa de estudos que me possibilitou cursar o mestrado, meu muito obrigada;

A toda minha família, em especial minhas irmãs Thabata e Ana Clara, meu companheiro Thiago e a todos meus queridos amigos que tornam minha caminhada mais tranquila e alegre;

Ao Conselho de Saúde do município de Itapecerica da Serra pelo voto de confiança e autorização para que a pesquisa pudesse ser iniciada;

A toda equipe de enfermagem, médica e de apoio do Pronto Socorro e Maternidade Municipal Zoraide Eva das Dores, pela autorização, pelo acolhimento, companhia e contribuição com a coleta de dados;

A todas as mulheres incríveis que aceitaram participar e que participaram desta pesquisa, sem elas nada seria possível, meu eterno agradecimento. 


\section{EPÍGRAFE}

"Imagina-te como uma parteira. Acompanhas o nascimento de alguém, sem exibição ou espalhafato. Tua tarefa é facilitar o que está acontecendo. Se deves assumir o comando, faz isso de tal modo que auxilies a mãe e deixes que ela continue livre e responsável. Quando nascer a criança, a mãe dirá com razão: nós três realizamos esse trabalho".

Lao-Tsé (séc. V a.C) 
Teixeira TT. Cola adesiva cirúrgica no reparo de lacerações perineais de primeiro grau no parto normal: estudo piloto aleatorizado controlado [dissertação]. São Paulo: Escola de Enfermagem, Universidade de São Paulo; 2018.

\section{RESUMO}

Introdução: $\mathrm{O}$ trauma perineal provocado pelo parto vaginal e seu reparo são importantes preocupações relacionadas ao períneo. A técnica ideal de reparo deve ser rápida, indolor, de fácil execução e que reduza a dor no puerpério. As evidências científicas apontam que a técnica e o material mais adequados para o reparo do trauma perineal são a sutura contínua e o fio poliglactina 910 de rápida absorção. Entretanto, em lacerações de primeiro e segundo graus, apesar de promover boa cicatrização, a sutura está relacionada à dor no períneo. A cola adesiva cirúrgica é um material utilizado em diversas cirurgias e especialidades médicas, com alto grau de resistência e facilidade no procedimento cirúrgico, o que parece se apresentar como uma alternativa eficaz no reparo perineal. Objetivo: Determinar a viabilidade de um ensaio clínico controlado e aleatorizado (ECA) sobre o uso da cola adesiva cirúrgica no reparo de lacerações perineais de primeiro grau durante o parto normal. Método: Estudo piloto paralelo, controlado e aleatorizado comparando a cola adesiva cirúrgica Epiglu® (etil2-cianoacrilato) com o fio Vicryl Rapide ${ }^{\circledR}$ (poliglactina 910) no reparo perineal, realizado no Pronto Socorro e Maternidade Municipal Zoraide Eva das Dores, Itapecerica da Serra-SP. A amostra foi constituída por 20 mulheres com lacerações perineais de primeiro grau com necessidade de reparo durante o parto normal, distribuídas no grupo experimental (GE; $n=10$; submetidas ao reparo com Epiglu ${ }^{\circledR}$ ) e grupo controle (GC; $\mathrm{n}=10$; submetidas ao reparo com sutura com Vicryl Rapide ${ }^{\circledR}$ ). O desfecho primário foi a ocorrência e intensidade da dor perineal após o parto e os desfechos secundários foram o processo de cicatrização, a satisfação da mulher com reparo perineal e o tempo dispendido pelo profissional para o reparo. Os desfechos foram avaliados pela Escala Visual Numérica de 11 pontos para intensidade da dor perineal; Escala REEDA, para cicatrização perineal; Escala Visual Analógica para satisfação da mulher; cronômetro digital para contagem do tempo de reparo dispendido em ambas as técnicas. Os dados foram coletados em quatro etapas: até 2 horas pós-parto, 12-24 horas, 36-48 horas e 10-20 dias pós-parto. Resultados: A média da intensidade da dor perineal foi significativamente menor entre as mulheres no GE, em todas as etapas do estudo (variação de 2,0-0,2 e 2,5-0,6 nos GE e GC, respectivamente). A cicatrização perineal apresentou escores significativamente melhores na escala REEDA entre as mulheres no GE, em todas as etapas (variação de 0,6-0,0 e 1,8-0,7, nos GE e GC, respectivamente). A satisfação das mulheres com reparo perineal foi significativamente superior no GE (100\% estavam satisfeitas ou muito satisfeitas), em comparação com o GC (10\% a $20 \%$ estavam insatisfeitas ou muito insatisfeitas). A média de tempo gasto para o reparo perineal foi 5 minutos no GE e 21 minutos no GC ( $<<0,001)$. Conclusão: O estudo mostrou que é viável adotar a técnica de reparo com Epiglu@ utilizada no estudo piloto, bem como os mesmos desfechos e períodos de seguimento pós-parto. Além disso, os resultados foram importantes para comparar os métodos de reparo perineal e calcular o tamanho da amostra para o ECA. Protocolo: O estudo foi registrado no Portal de Registro Brasileiro de Ensaios Clínicos http://www.ensaiosclinicos.gov.br/rg/RBR-2h84gt/

Palavras-chave: Parto. Períneo. Lacerações. Adesivos Teciduais. Cianoacrilatos. Enfermagem Obstétrica. 
Teixeira TT. Tissue adhesive for first-degree perineal tears repairing during normal delivery: a pilot randomized controlled trial [dissertation]. Sao Paulo: School of Nursing, University of Sao Paulo; 2018.

\begin{abstract}
Introduction: One of the important concerns regarding the perineum is the trauma caused by the vaginal delivery and perinealrepair. The ideal perineal repair technique should be quick, painless, easy to perform in order to decrease pain in the puerperium. The scientific evidence indicates that the most suitable technique and material for the repair of perineal trauma are continuous suture and the polyglactin 910 rapid absorption thread. However, in the first and second degrees lacerations, despite promoting good healing, the suture is associated with perineum pain. The surgical adhesive is a tool used in several surgeries and medical specialties, had high resistance and is ease to manage during the surgical procedure, which seems to be an effective alternative for perineal repair. Objective: To determine the feasibility of a clinical randomized controlled trial (RCT) on the use of surgical adhesive in the repair of first-degree perineal trauma during vaginal delivery. Methods: Parallel, controlled and randomized pilot study comparing the outcomes of the use of surgical adhesive glue Epiglu ${ }^{\mathrm{TM}}$ (ethyl-2-cyanoacrylate) and Vicryl Rapide ${ }^{\mathrm{TM}}$ (polyglactin 910) thread in perineal repair. The research was performed at Pronto Socorro e Maternidade Zoraide Eva das Dores, Itapecerica da Serra-SP, Brazil. The sample comprised 20 women with first-degree perineal trauma that need repair during normal delivery, distributed in experimental group ( $\mathrm{EG}, \mathrm{n}=10$, undergoing repair with Epiglu ${ }^{\mathrm{TM}}$ ) and control group (CG;n=10, undergoing repair with Vicryl Rapide ${ }^{\mathrm{TM}}$ ). The primary outcome was the occurrence and intensity of perineal pain after delivery and secondary outcomes were healing process, the woman's satisfaction on perineal repair and the time spent by the professional to repair the trauma. The outcomes were evaluated by the 11-point Visual Numeric Scale for perineal pain intensity; REEDA Scale for perineal healing; Visual Analogue Scale for women's satisfaction; digital stopwatch for counting the repair time in both suture techniques. Data were collected in four stages: up to 2 hours after delivery, 12-24 hours, 3648 hours and 10-20 days postpartum. Results: In all study stages, the average of the intensity of perineal pain among women in EG was significantly lower than CG (variation of 2.0-0.2 in EG and 2.5-0.6 in CG). In all stages, perineal healing showed significantly better REEDA scale scores among women in EG, (variation of 0.6-0.0 in EG and 1.8-0.7 in CG). The women's satisfaction with perineal repair was significantly higher in EG $(100 \%$ were satisfied or very satisfied), compared with CG (10\% to $20 \%$ were unsatisfied or very unsatisfied). The average time for perineal repair was 5 minutes in EG and 21 minutes in CG ( $\mathrm{p}<0.001)$. Conclusion: The results of the study were important to compare perineal repair methods and calculate the sample size for the future RCT. In addition, we showed that is possible to adopt the perineal repair technique with Epiglu ${ }^{\mathrm{TM}}$ developed in the pilot study, as well as the same outcomes and postpartum follow-up periods. Protocol: The study was registered in the Brazilian Clinical Trials Registry http://www.ensaiosclinicos.gov.br/rg/RBR-2h84gt/
\end{abstract}

Keywords: Parturition. Perineum. Lacerations. Tissue Adhesives. Cyanoacrylates. Nursing. Midwifery. 
Teixeira TT. Adhesivo tisular para reparación de laceraciones perineales de primer grado en el parto normal: estudio piloto aleatorizado controlado [disertación]. Sao Paulo: Escuela de Enfermería, Universidad de Sao Paulo; 2018.

\section{RESUMEN}

Introducción: El trauma perineal provocado por el parto vaginal y su reparación son importantes preocupaciones relacionadas con el perineo. La técnica ideal de reparación debe ser rápida, indolora, de fácil ejecución y que reduzca el dolor en el puerperio. Las evidencias científicas apuntan que la técnica y el material más adecuados para la reparación del trauma perineal son la sutura continua y el hilo poliglactina 910 de rápida absorción. Sin embargo, en las laceraciones de primer y segundo grado, a pesar de promover una buena cicatrización, la sutura está relacionada con el dolor en el perineo. El adhesivo quirúrgico es un material utilizado en diversas cirugías y especialidades médicas, con alto grado de resistencia y facilidad en el procedimiento quirúrgico, lo que parece presentarse como una alternativa eficaz en la reparación perineal. Objetivo: Determinar la viabilidad de un ensayo clínico controlado y aleatorizado (ECA) sobre el uso del adhesivo quirúrgico en la reparación de las laceraciones perineales de primer grado durante el parto normal. Método: Estudio piloto paralelo, controlado y aleatorizado comparando el pegamento adhesivo quirúrgico Epiglu® (etil-2-cianoacrilato) con el hilo Vicryl Rapide® (poliglactina 910) en la reparación perineal, realizado en el Pronto Socorro y Maternidad Zoraide Eva das Dores, Itapecerica da Serra-SP, Brasil. La muestra fue constituida por 20 mujeres con laceraciones perineales de primer grado con necesidad de reparación durante el parto normal, distribuidas en el grupo experimental (GE, $\mathrm{n}=10$, sometidas a la reparación con Epiglu $®$ ) y grupo control (GC; $n=10$; sometidas a la reparación con sutura con Vicryl Rapide $®$ ). El desenlace primario fue la ocurrencia e intensidad del dolor perineal después del parto y los desenlaces secundarios fueron el proceso de cicatrización, la satisfacción de la mujer con la reparación perineal y el tiempo empleado por el profesional para la reparación. Los resultados fueron evaluados por la Escala Visual Numérica de 11 puntos para intensidad del dolor perineal; Escala REEDA, para la cicatrización perineal; Escala Visual Analógica para la satisfacción de la mujer; cronómetro digital para el recuento del tiempo de reparación en ambas técnicas. Los datos fueron recolectados en cuatro etapas: hasta 2 horas después del parto, 12-24 horas, 36-48 horas y 10-20 días posparto. Resultados: La media de la intensidad del dolor perineal fue significativamente menor entre las mujeres en el GE, en todas las etapas del estudio (variación de 2,0-0,2 y 2,5-0,6 en los GE y GC, respectivamente). La cicatrización perineal presentó puntuaciones significativamente mejores en la escala REEDA entre las mujeres en el GE, en todas las etapas (variación de 0,6-0,0 y 1,8-0,7, en los GE y GC, respectivamente). La satisfacción de las mujeres con reparación perineal fue significativamente superior en el GE (100\% estaban satisfechas o muy satisfechas), en comparación con el GC (10\% a $20 \%$ estaban insatisfechas o muy insatisfechas). El promedio de tiempo empleado para la reparación perineal fue de 5 minutos en GE y 21 minutos en el GC ( $<<0,001)$. Conclusión: El estudio mostró que es posible adoptar la técnica de reparación con Epiglu ${ }^{\circledR}$ desarrollada en el estudio piloto, así como los mismos desenlaces y períodos de seguimiento posparto. Además, los resultados fueron importantes para comparar los métodos de reparación perineal y calcular el tamaño de la muestra para el ECA. Protocolo: El estudio fue registrado en el Portal de Registro Brasileño de Ensayos Clínicos http://www.ensaiosclinicos.gov.br/rg/RBR-2h84gt/

Palabras-clave: Parto. Perineo. Laceraciones. Adhesivos Tisulares Cianoacrilatos. Enfermería Obstétrica. 


\section{LISTA DE QUADROS}

Quadro 1-Estudos utilizando colas adesivas cirúrgicas no reparo de lacerações perineais 27

Quadro 2- Colas adesivas cirúrgicas disponíveis no mercado brasileiro .......................... 31 


\section{LISTA DE FIGURAS}

Figura 1- Escala REEDA de avaliação da hiperemia, edema, equimose, secreção e coaptação de bordas da lesão

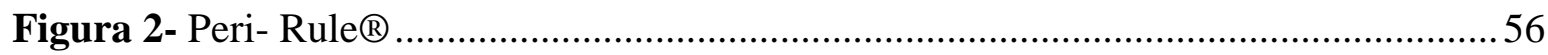

Figura 3- Fluxograma das participantes, Itapecerica da Serra, SP - 2017......................66

Figura 4- Ilustração da região perineal e estruturas acometidas com lacerações de primeiro grau, Itapecerica da Serra, SP - 2017

Figura 5- Evolução da dor perineal segundo o escore a EVN nos grupos experimental (GE) e controle (GC) nas Etapas 1 a 4 do estudo, Itapecerica da Serra, SP - 2017

Figura 6- Evolução do processo cicatricial segundo escore da escala REEDA nos grupos experimental (GE) e controle (GC) nas Etapas 2 a 4 do estudo, Itapecerica da Serra, SP 2017

Figura 7- Evolução do edema perineal nos grupos experimental (GE) e controle (GC) nas Etapas 2 a 4 do estudo, Itapecerica da Serra, SP - 2017

Figura 8- Evolução da equimose perineal nos grupos experimental (GE) e controle (GC) nas Etapas 2 a 4 do estudo, Itapecerica da Serra, SP - 2017

Figura 9- Evolução da coaptação das bordas da laceração perineal nos grupos experimental (GE) e controle (GC) nas Etapas 2 a 4 do estudo, Itapecerica da Serra, SP - 2017

Figura 10- Satisfação da mulher com reparo perineal nos grupos experimental (GE) e controle (GC) nas Etapas 1 a 4 do estudo, Itapecerica da Serra, SP - 2017

Figura 11- Reparo no pequeno lábio esquerdo realizado com fio de sutura Vicryl Rapide® nas Etapas 1 a 4 do estudo, Itapecerica da Serra, SP - 2017

Figura 12- Reparo na fúrcula e corpo perineal realizado com cola adesiva cirúrgica Epiglu ${ }^{\circledR}$ nas Etapas 1 a 4 do estudo, Itapecerica da Serra, SP - 2017 


\section{LISTA DE TABELAS}

Tabela 1- Características das mulheres dos grupos experimental (GE) e controle (GC), segundo variáveis categóricas e valor-p, Itapecerica da Serra, SP - 2017.

Tabela 2- Caracterização das mulheres dos grupos experimental e controle, segundo variáveis numéricas e valor-p, Itapecerica da Serra, SP - 2017

Tabela 3- Tempo de reparo perineal, em minutos, nos grupos experimental e controle, Itapecerica da Serra, SP - 2017

Tabela 4- Distribuição das mulheres dos grupos experimental e controle segundo a dor perineal nas Etapas 1 a 4 do estudo e valor-p, Itapecerica da Serra, SP - 2017

Tabela 5- Distribuição das mulheres dos grupos experimental e controle segundo o escore da escala REEDA nas Etapas 2 a 4 do estudo e valor-p, Itapecerica da Serra, SP - 2017 ...73

Tabela 6- Distribuição das mulheres dos grupos experimental e controle segundo o escore do edema perineal nas Etapas 2 a 4 do estudo e valor-p, Itapecerica da Serra, SP - 2017...74

Tabela 7- Distribuição das mulheres dos grupos experimental e controle segundo o escore da equimose perineal nas Etapas 2 a 4 do estudo e valor-p, Itapecerica da Serra, SP - 2017

Tabela 8- Distribuição das mulheres dos grupos experimental e controle segundo o escore da coaptação das bordas da laceração perineal nas Etapas 2 a 4 do estudo e valor-p, Itapecerica da Serra, SP, 2017

Tabela 9- Satisfação das mulheres dos grupos experimental (GE) e controle (GC) em relação ao reparo perineal nas Etapas 1 a 4 do estudo, Itapecerica da Serra, SP - 2017 ......78 


\section{LISTA DE SIGLAS}

$\begin{array}{ll}\text { AC } & \text { Alojamento conjunto } \\ \text { Mas } & \text { Autarquia Municipal de Saúde } \\ \text { ANVISA } & \text { Agência Nacional de Vigilância Sanitária } \\ \text { Cm } & \text { Centímetros } \\ \text { CPN } & \text { Centro de Parto Normal } \\ \text { EACH } & \text { Escola de Artes, Ciências e Humanidades } \\ \text { EVA } & \text { Escala Visual Analógica } \\ \text { EVN } & \text { Escala Visual Numérica } \\ \text { GC } & \text { Grupo Controle } \\ \text { GE } & \text { Grupo Experimental } \\ \text { GEE } & \text { Generalized Estimating Equation } \\ \text { IBGE } & \text { Instituto Brasileiro de Geografia e Estatística } \\ \text { KM } & \text { Quilômetro } \\ \text { LMM } & \text { Linear Mixed Model } \\ \text { PSMMZED } & \text { Pronto Socorro e Maternidade Municipal } \\ \text { RN } & \text { Zoraide Eva das Dores } \\ \text { USP } & \text { Recém-nascido } \\ & \text { Universidade de São Paulo }\end{array}$




\section{SUMÁRIO}

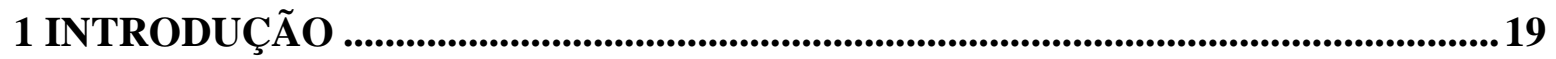

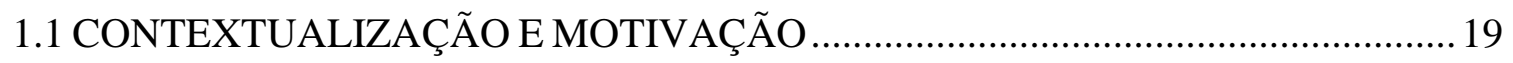

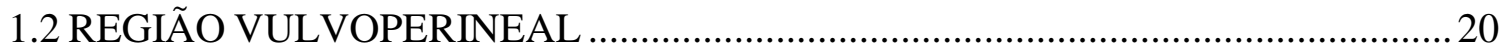

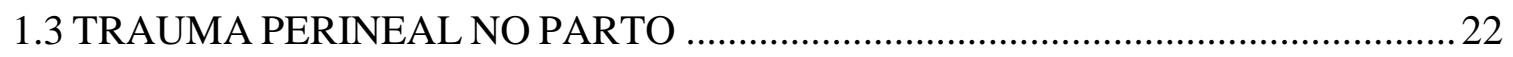

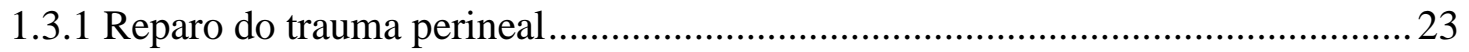

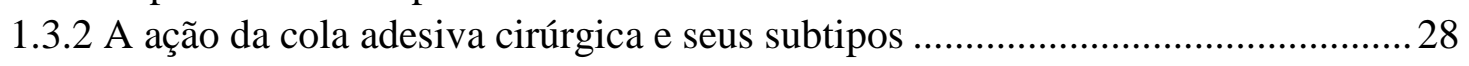

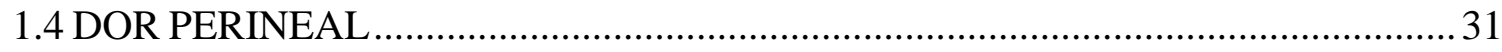

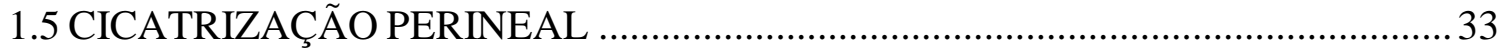

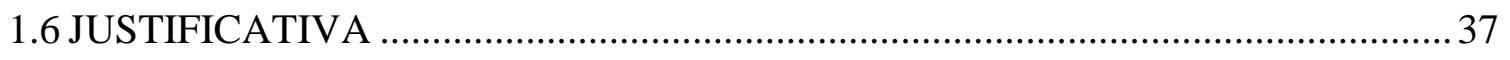

2 HIPÓTESE CONCEITUAL .................................................................................

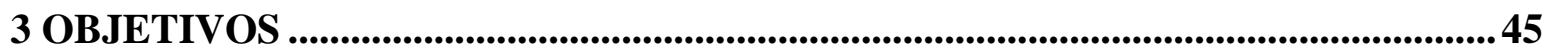

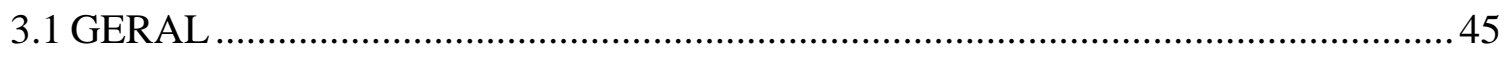

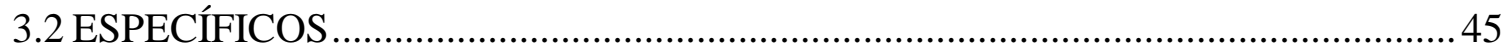

4 MÉTODO ...............................................................................................................................49

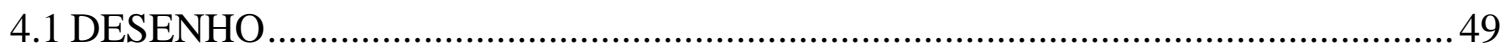

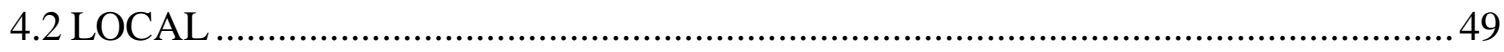

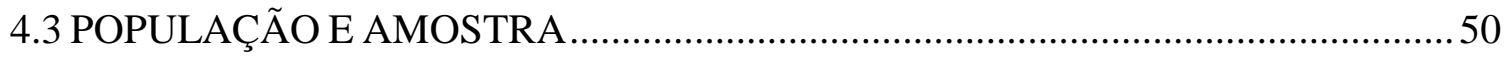

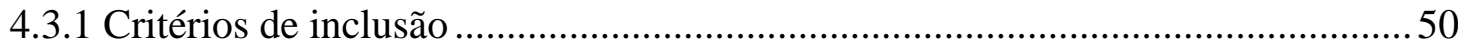

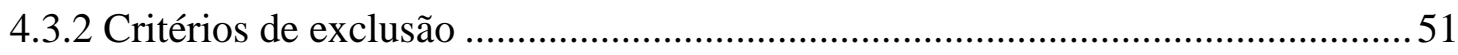

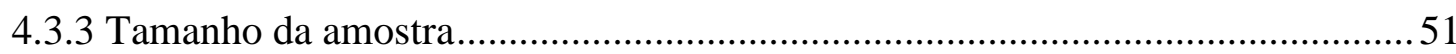

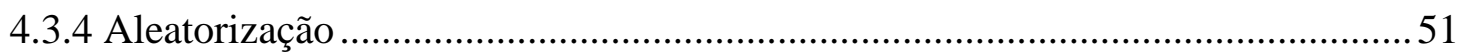

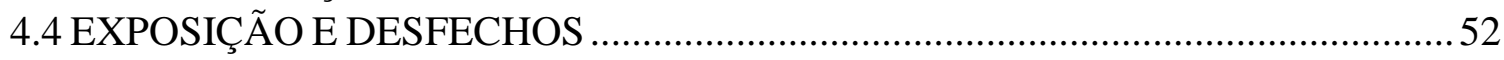

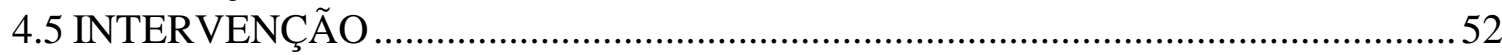

4.5.1 Reparo da laceração perineal com cola adesiva cirúrgica ....................................52

4.5.2 Reparo da laceração perineal com fio de sutura ...................................................53

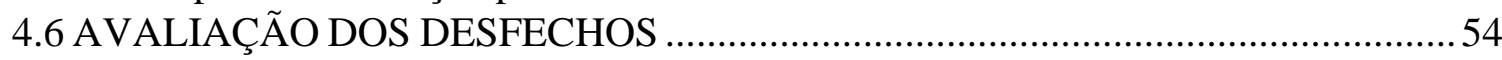

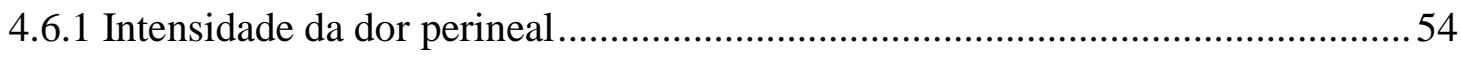

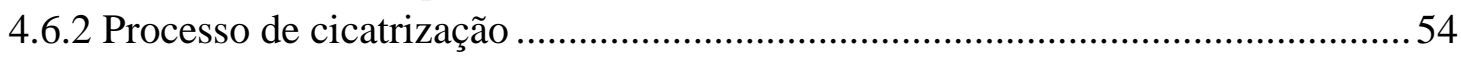

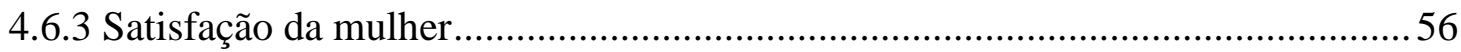

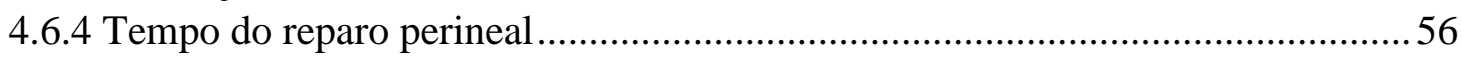

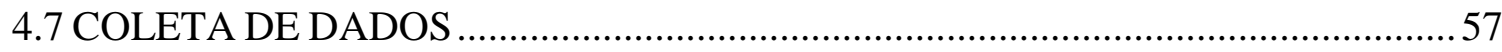

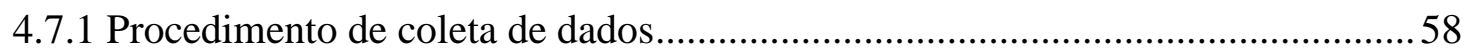

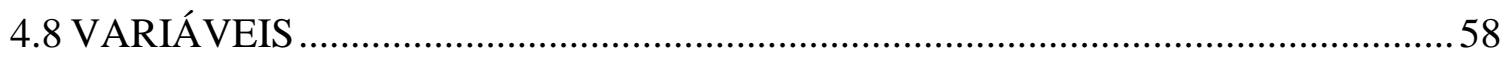

4.8.1 Variáveis dependentes ...........................................................................58

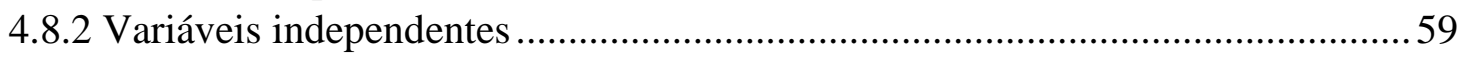

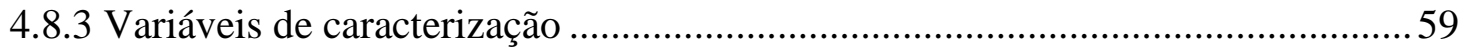

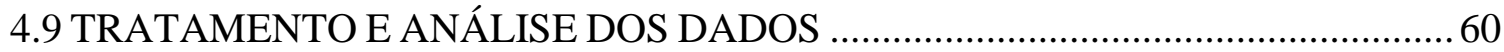

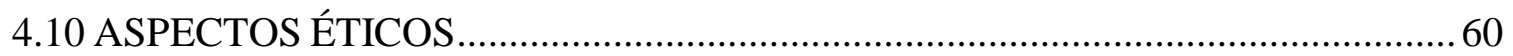

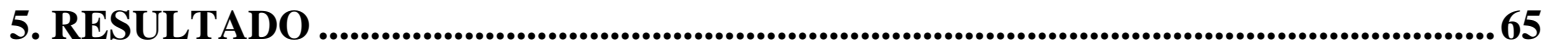




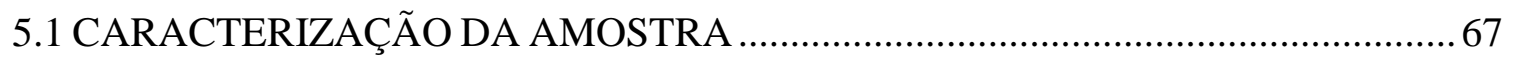

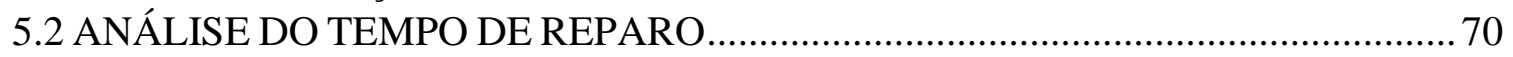

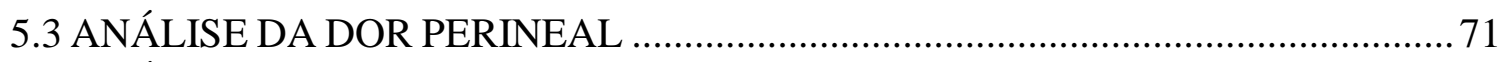

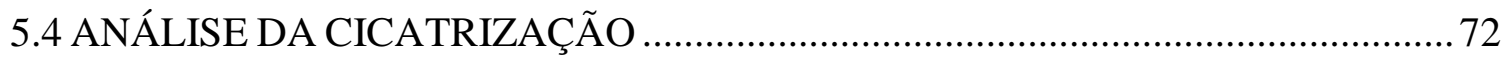

5.5 ANÁLISE DA SATISFAÇÃO COM O REPARO PERINEAL ..................................78

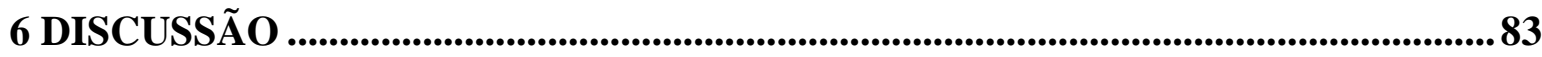

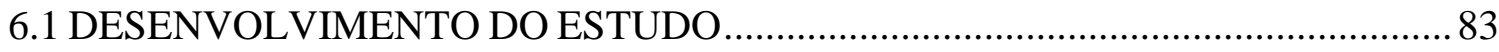

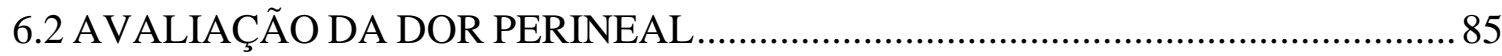

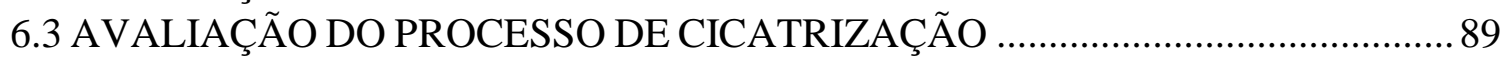

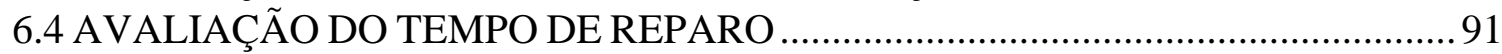

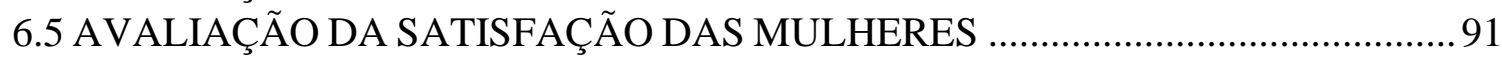

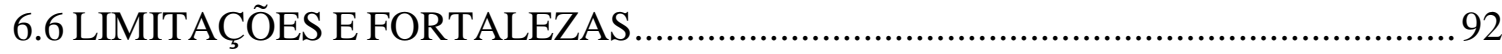

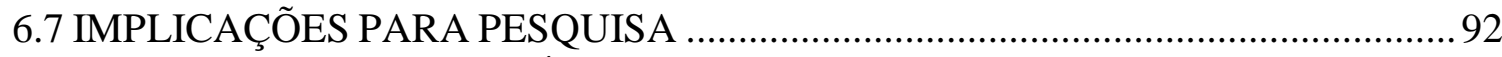

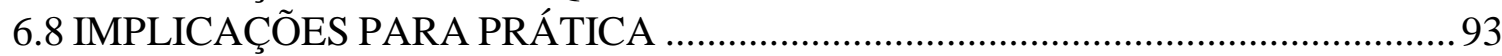

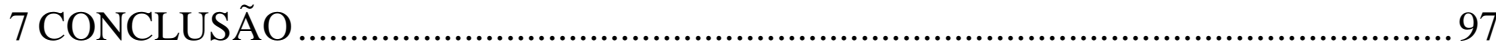

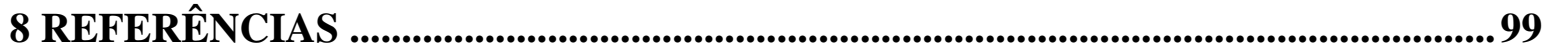

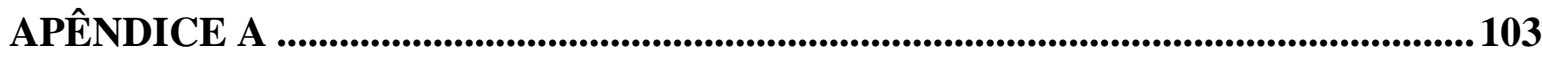

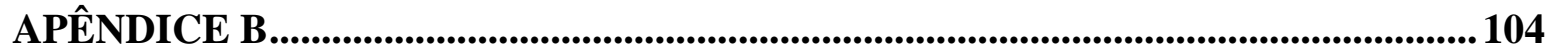

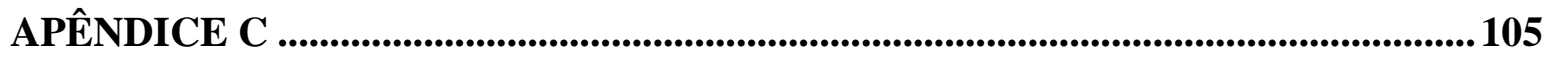

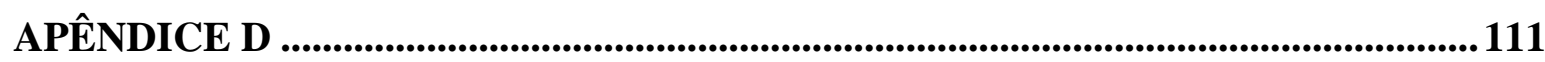

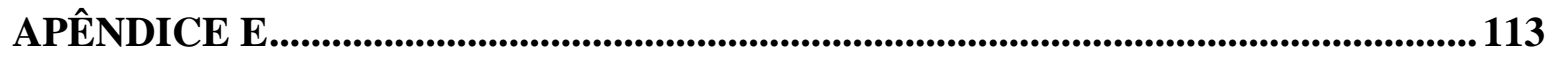

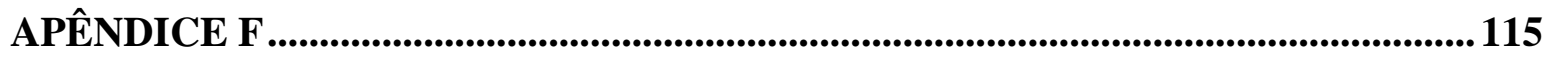

ANEXO 1...........................................................................................................117

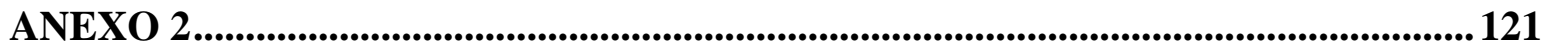


1 INTRODUÇÃO 


\section{INTRODUÇÃO}

\subsection{CONTEXTUALIZAÇÃO E MOTIVAÇÃo}

Durante a graduação em Obstetrícia, sempre foi destacada a importância do cuidado integral à saúde da mulher baseado nas melhores evidências científicas e com recursos que visam aperfeiçoar o cuidado prestado. Nesse período e na minha atuação como obstetriz, tive a oportunidade de acompanhar diversas mulheres relatando seus partos e em suas falas era recorrente apontar o parto como um dos momentos mais intensos e significativos de suas vidas.

A percepção do período gravídico-puerperal pode ser construída a partir de diversas questões e cabe ao profissional responsável pela assistência apresentar recursos que possibilitem tornar essa experiência a mais agradável possível, através de medidas de promoção da saúde materna e neonatal e de redução de possíveis danos causados pela prática assistencial.

O parto por vezes é associado à dor, o que gera ansiedade e medo nas mulheres; muitas vezes, esse medo relaciona-se também à manutenção da integridade da região perineal. As queixas relacionadas ao incômodo no momento do reparo perineal me fizeram refletir e buscar intervenções efetivas que pudessem reduzir o incômodo nesse período.

No reparo das lacerações perineais é recorrente a queixa dolorosa, mesmo após a anestesia local, principalmente em tecidos mais superficiais (pele, mucosa e uniões mucocutâneas). Vale ressaltar que é comum não realizar o reparo em lacerações de primeiro grau e, quando realizado, o método adotado é a sutura.

Diante dessa condição, emergiu a seguinte questão: há métodos de reparo perineal alternativos que causem menos incômodo nas mulheres com laceração perineal de primeiro grau? A fim de encontrar resposta à questão, realizei a revisão de literatura, descrita a seguir. 


\subsection{REGIÃO VULVOPERINEAL}

O sistema genital feminino é dividido em genitália interna e externa. A região externa compreende a área vulvoperineal e inclui o monte de vênus, formações labiais (grandes e pequenos lábios), espaço interlabial (vestíbulo, meato uretral, introito vaginal e hímen), órgãos eréteis (clitóris e bulbovestibulares) e glândulas acessórias (parauretrais e vulvovaginais) (Rezende, Montenegro, 2014).

A vulva é uma região altamente vascularizada, o que lhe confere coloração específica, nota-se diferença na mesma durante a gestação devido ao aumento da vascularização. As artérias responsáveis pela vascularização da região são as artérias pudenda externa e interna (Cabar et al., 2016).

O monte de vênus é uma elevação mediana à sínfise púbica e, assim como toda região vulvar externa, é coberta por um tecido rico em folículos pilosos, glândulas sebáceas e sudoríparas. Na região dos pequenos lábios, clitóris e vestibular há uma alteração no tecido, que deixa de apresentar pelos e tem umidade acentuada. Em condições normais, a vulva protege o meato urinário fisicamente (Rezende, Montenegro, 2014 Cabar et al., 2016).

Os grandes lábios são contínuos ao monte de vênus e estendem-se até a região perineal; em sua porção média, apresentam uma fenda, que se estende até o limite inferior da vulva, área denominada fúrcula. Na área interna aos grandes lábios estão os pequenos lábios, que em seu limite superior englobam o clitóris, formando seu freio e prepúcio; sua porção final pode estar fundida com os grandes lábios, na porção média ou na região da fúrcula. A área interna aos pequenos lábios é denominada vestíbulo da vagina (Rezende, Montenegro, 2014).

A área vestibular é demarcada pelos pequenos lábios, clitóris e borda posterior do hímen. Fazem parte desta região o orifício da uretra, introito vaginal, glândulas parauretrais (Skene) e vulvovaginais (Bartholin). Por vezes, após o primeiro coito e sempre após o parto vaginal, há o rompimento do hímen, que passa a se denominar carúnculas mirtiformes (Rezende, Montenegro, 2014; Cabar et al., 2016).

A vagina é um canal tubular que possui uma extensão do colo uterino ao introito vaginal, aproximadamente 8 a 10 centímetros. Sua maior porção localiza-se acima do diafragma pélvico e os músculos bulbocavernosos estão localizados em torno do introito 
vaginal. Os tecidos que constituem a vagina são a túnica mucosa, a muscular e a adventícia. O epitélio vaginal responde a oscilações hormonais do ciclo sexual feminino e suas células são ricas em glicogênio, tornando seu pH ácido, por volta de 4 a 4,5 (Cabar et al., 2016).

O períneo (ou região vulvoperineal) é a região losângica na área genital externa feminina, situado entre a sínfise púbica e o cóccix. É dividido, anatomicamente, pelo traçado da linha bi isquiática em duas regiões: o trígono urogenital (área anterior) e trígono anal (área posterior) (Cabar et al., 2016). Faz parte desta região, um conjunto de músculos e aponeuroses que fecha a parte inferior da cavidade pélvica, atravessado pelo reto, posteriormente, e pela vagina e uretra, anteriormente. Esse conjunto é denominado diafragma ou assoalho pélvico (Rezende, Montenegro, 2014).

Os músculos que compreendem a camada profunda do diafragma pélvico são: levantadores do ânus (pubococcígeo, puborretal, pubovaginal e iliococcígeo) e coccígeo (ou isquiococcígeo), além do obturador interno e pirifome, que cobrem as paredes da pelve. Os músculos da camada superficial são: bulbocavernoso, isquiocavernoso, transversos superficial e profundo e esfíncter externo do ânus. Esses músculos são constituídos por dois tipos de fibras, as do tipo 1 e as do tipo 2, responsáveis pela contração lenta e contração rápida, respectivamente. São responsáveis pela sustentação de vísceras pélvicas, ereção do clitóris, constrição da uretra e vagina e auxílio na evacuação. O músculo elevador do ânus é composto por aproximadamente $70 \%$ de fibras tipo 1, mantendo tônus constante desta região de modo a garantir o suporte das vísceras pélvicas (Gosling et al., 1981).

A vulva possui inervações simpática e parassimpática, além das inervações somáticas, responsáveis pela resposta motora e sensorial, respectivamente. O assoalho pélvico é inervado pelos nervos pudendo e perineal, nervos retais inferiores e ramos perineais do nervo femuorocutâneo posterior (Cabar et al., 2016).

As estruturas anatômicas citadas acima podem ser acometidas por traumas durante o parto vaginal e, devido a esse fato, após o parto a região perineal é avaliada para identificar possíveis lacerações de trajeto. Uma vez identificada, tais lacerações serão avaliadas através de sua extensão e profundidade, classificadas de acordo com as estruturas acometidas e verificada a necessidade de reparo (Bols et al., 2010). 


\subsection{TRAUMA PERINEAL NO PARTO}

O trauma perineal pode ocorrer de maneira espontânea como uma laceração ou, no caso da episiotomia, é provocado pela incisão cirúrgica na região perineal, realizada pelo profissional que assiste ao parto (Fernando et al., 2013). O local do trauma perineal pode ser definido como anterior quando compreende qualquer lesão nos lábios, clitóris, parede anterior da vagina e vulva ou posterior quando compreende lesão na parede vaginal posterior, músculos perineais e esfíncteres anais (Henderson, 2006). Geralmente, é mais extenso na primeira experiência de parto vaginal e possui como fatores de risco o tamanho fetal, parto instrumental, má apresentação e posicionamento fetal, posição materna e puxos prolongados (Frolich, Kettle, 2015).

As lacerações perineais relacionadas ao parto são classificadas de acordo com as estruturas anatômicas envolvidas. São de primeiro grau quando afetam a pele e mucosa, segundo grau quando atingem músculos perineais e terceiro grau quando atingem o esfíncter do ânus. As de terceiro grau se subdividem em 3a, quando menos de $50 \%$ do esfíncter anal externo é atingido; 3 b quando mais de $50 \%$ do esfíncter anal externo é atingido e 3c quando o esfíncter anal interno também é atingido. São classificadas de quarto grau quando envolvem o complexo do esfíncter e o epitélio anal (Sultan, 1999).

Estima-se ainda que as lacerações espontâneas que requerem sutura ocorrem em um terço das mulheres que deram à luz por parto vaginal, no Reino Unido e Estados Unidos. Segundo revisão sistemática que incluiu 38 estudos, mais de $85 \%$ das mulheres sofreram algum tipo de trauma perineal (Frolich, Kettle, 2015).

Estudo observacional prospectivo, realizado na Inglaterra, verificou que dentre os partos vaginais, somente $9,6 \%$ das nulíparas e 31,2\% das multíparas tiveram períneo íntegro (Smith et al., 2013).

A Pesquisa Nacional de Demografia e Saúde da Criança e da Mulher, conduzida pelo Ministério da Saúde em 2006, aponta que 71,6\% das mulheres com parto normal foram submetidas à episiotomia na condução do parto vaginal (Brasil, 2008). O estudo "Nascer no Brasil: Inquérito Nacional sobre Parto e Nascimento" verificou que 56\% das mulheres que tiveram parto normal receberam episiotomia (Leal et al., 2014). 
Estudo retrospectivo brasileiro com 6.365 partos vaginais apurou que 28,6\% das mulheres apresentaram períneo íntegro, 45,5\% apresentaram lacerações e 25,9\% receberam episiotomia. $\mathrm{O}$ estudo concluiu que o desfecho perineal esteve relacionado à paridade, prematuridade, peso e vitalidade do recém-nascido (Riesco et al., 2011).

\subsubsection{Reparo do trauma perineal}

Usualmente, o reparo do períneo no parto se dá através da sutura com fio e a cicatrização ocorre por primeira intenção. Os estudos voltam-se para detectar as melhores técnicas e materiais para este fim. As comparações entre tipos de técnicas e fios de sutura procuram estabelecer superioridade de alguma técnica e material em relação à dor, cicatrização, dispareunia e satisfação da mulher (Frolich, Kettle, 2015).

A técnica ideal de reparo perineal precisa ser rápida, indolor, de fácil execução e que diminua a dor no puerpério (Feigenberg et al., 2014). O fio de sutura mais apropriado para o reparo perineal é a poliglactina 910 de rápida absorção (Vicryl Rapide®). Já a técnica de sutura associada à menor dor local em curto prazo e menos necessidade de analgesia e de remoção de fios é a sutura contínua com o fio poliglactina 910 de rápida absorção (Kettle et al., 2012).

Estudos que visam encontrar a melhor técnica de reparo de traumas perineais também comparam o uso da sutura e não-sutura, uma vez que a correção cirúrgica pode estar associada a resultados adversos, como dor, desconforto e interferência nas atividades cotidianas do puerpério (Elharmeel et al., 2011).

Revisão da Biblioteca Cochrane concluiu que as evidências envolvendo reparo por sutura e não-sutura nas lacerações de primeiro e segundo graus são limitadas e recomenda que a decisão da correção de lacerações perineais por sutura deve ser tomada pelo

profissional, mediante a análise clínica e a preferência da mulher, após informações sobre a falta de resultados a longo prazo e a possibilidade de um processo de cicatrização mais lento no caso da não-sutura, entretanto com possibilidade de melhor sensação de bem-estar (Elharmeel et al., 2011).

Atualmente, a recomendação no Brasil é aconselhar a mulher com lacerações de segundo grau a realizar o reparo com sutura, a fim de uma melhor cicatrização. Nos casos de 
lacerações de primeiro grau, aconselha-se que a ferida seja suturada com o intuito de melhorar a cicatrização, a menos que as bordas da mesma estejam bem apostas (Brasil, 2016). A mesma recomendação é orientada pelo National Institute for Health and Care Excellence, do Reino Unido (Nice, 2017)

Além do fio de sutura, outros materiais estão em desenvolvimento com a finalidade de garantir melhores resultados estéticos, maior conforto e menos reações inflamatórias, como a cola cirúrgica, também denominada adesivo cirúrgico. A fim de adotar uma nomenclatura padrão para o presente estudo, o termo utilizado será cola adesiva cirúrgica. Esse material é utilizado em outras especialidades médicas, como a cirurgia plástica, e apresenta alto grau de resistência, além de promover facilidade no procedimento cirúrgico (Dehne et al., 2012).

Revisão da Biblioteca Cochrane, atualizada em 2014, comparou o uso de colas adesivas cirúrgicas com as técnicas tradicionais de suturas em diversos tipos de cirurgia, como blefaroplastia, laparoscopia, herniotomias e aplicação de telas cirúrgicas, entre outros. Foram incluídos 33 estudos com 2.793 pacientes, abordando fechamentos cirúrgicos em diversos tipos de intervenções. As conclusões encontradas foram que as suturas têm menor taxa de deiscência, entretanto, enfatizam a necessidade de mais estudos bem desenhados e randomizados comparando colas adesivas cirúrgicas com métodos alternativos de fechamento, abrangendo locais cirúrgicos de alta tensão (Dumville et al., 2014).

O reparo perineal com a cola adesiva cirúrgica parece se apresentar como uma boa alternativa, uma vez que estudos que a utilizaram para este fim apresentaram resultados positivos quanto à cicatrização, estética e diminuição da dor local (Bowen, Selinger, 2002; Berger, Worly, 2013; Feigenberg et al., 2014).

Um ensaio clínico controlado e randomizado comparou o reparo da pele na incisão de episiotomia com fio de sutura Vicryl Rapide ${ }^{\circ}$ com a cola adesiva cirúrgica Dermabond®. Foi analisado o reparo realizado em 100 primigestas, 50 em cada grupo. O estudo concluiu que o uso da cola adesiva cirúrgica é eficaz e segura para o fechamento da pele em episiotomias, além do fato da cola proporcionar menor tempo de reparo, menor dor durante e após o procedimento e o processo de cicatrização e a cosmética serem similares entre ambos os grupos (Chamariya, Prasad, Chauhan, 2016). 
Estudo prospectivo randomizado e controlado avaliou a efetividade da cola adesiva cirúrgica no reparo de lacerações perineais de primeiro grau. A amostra de 102 mulheres foi randomizada; 28 foram reparadas com sutura através do fio Vicryl Rapide® e as outras 74 mulheres foram submetidas ao reparo perineal com cola adesiva cirúrgica a base de octil-2cianoacrialato (Dermabond®). Os resultados encontrados demonstram que o uso da cola está relacionado com menor dor e menor tempo de reparo do trauma, associado a resultados cosméticos e funcionais semelhantes à sutura convencional. Os autores afirmam que mais ensaios clínicos são necessários para validar seus resultados, bem como estudos sobre o uso da cola em lacerações de segundo e terceiro graus e episiotomia (Feigenberg et al., 2014).

Um estudo de caso relatou o uso da Dermabond® para o reparo de lesão no clitóris que comprometia grande parte da sua estrutura (apresentava avulsão do corpo clitoriano). Foi utilizada somente a cola adesiva cirúrgica no reparo, que apresentou um resultado satisfatório relacionado à cicatrização, melhora da dor e volta à função sexual (Berger, Worly, 2013).

Mota et al. (2009) conduziram um ensaio clínico randomizado comparando o reparo da pele da região perineal após episiotomia, utilizando a cola adesiva cirúrgica Dermabond® e sutura subcuticular. A amostra foi composta de 100 mulheres submetidas à episiotomia, das quais 53 foram submetidas à aproximação da pele com cola adesiva cirúrgica Dermabond ${ }^{\circ}$ e 47 com sutura subcuticular com Vicryl®. Contrapondo-se aos resultados obtidos no estudo de Feigenberg et al. (2014), nesse estudo não houve diferença significativa na dor perineal em curto e longo prazos ou retorno da atividade sexual. Entretanto, o tempo de procedimento na utilização da cola foi inferior ao da sutura com fio. Na sua conclusão, evidenciou-se que mais estudos são importantes para confirmar esses resultados, tendo em vista que ainda não há evidências científicas para apoiar o uso da cola adesiva cirúrgica no reparo de episiotomias.

Bowen e Selinger (2002) realizaram um estudo prospectivo controlado para comparar o uso do adesivo de embucrilato (ou butilcianoacrilato) com a sutura subcuticular utilizando fio de ácido poliglicólico no fechamento da episiotomia. A amostra foi composta por 62 mulheres, das quais 32 integraram o grupo da cola e as demais, o grupo de sutura subcuticular. Os resultados mostraram que o grupo de mulheres que foram submetidas ao reparo da episiotomia com a cola adesiva cirúrgica teve menos dor pós-parto durante caminhadas e voltou a ter relações sexuais sem dor mais cedo, em comparação ao grupo 
submetido à sutura. O estudo concluiu que o reparo com embucrilato é superior ao da sutura e que esse estudo pode servir de base para novos estudos em grande escala.

No estudo de Rogerson, Mason e Roberts (2000), com amostra de 20 mulheres, utilizou-se a cola adesiva cirúrgica Indermil® (n-butil-2-cianoacrilato) no reparo da pele em lesões perineais de segundo grau e episiotomia. No reparo de músculos e mucosa foi utilizada a sutura com Vicryl®. Dos 20 partos, quatro apresentaram lacerações de segundo grau e os outros 16 episiotomia. No contato posterior com as mulheres, duas se queixaram de excesso da cola, retirada então com tesoura, e em outros dois casos foi observado defeito na aposição da pele, que foi sanado naturalmente sem qualquer intervenção. Segundo os autores, a técnica de reparo da pele com cola adesiva cirúrgica é muito promissora, apresentando um fechamento rápido e indolor da pele e precisa ser estudada em ensaios clínicos randomizados.

Um dos primeiros estudos que comparou o efeito cola adesiva cirúrgica em comparação com a sutura com fio foi o de Adoni e Anteby (1991). O estudo comparou o Histoacryl ${ }^{\circledR}$ com o categute cromado no reparo da episiotomia em 20 mulheres. O Histoacryl ${ }^{\circledR}$ foi superior ao categute, uma vez que as mulheres submetidas a essa intervenção apresentaram menor dor ao caminhar, sentar, dormir, deitar, amamentar, urinar e evacuar.

A seguir, os dados do Quadro 1 sumarizam os principais estudos referidos. 
Quadro 1-Estudos utilizando colas adesivas cirúrgicas no reparo de lacerações perineais

\begin{tabular}{|c|c|c|c|}
\hline $\begin{array}{l}\text { Autor, } \\
\text { Ano, País }\end{array}$ & Objetivos & $\begin{array}{c}\text { Método } \\
\text { Desenho/Amostra/Intervenção }\end{array}$ & Principais resultados \\
\hline $\begin{array}{l}\text { Chamariya, } \\
\text { Prasad e } \\
\text { Chauhan } \\
2016\end{array}$ & $\begin{array}{l}\text { Comparar o reparo } \\
\text { da pele em } \\
\text { episiotomias com } \\
\text { Dermabond® e } \\
\text { Vicryl Rapide } ®\end{array}$ & $\begin{array}{l}\text { Estudo prospectivo controlado e } \\
\text { randomizado/ } 100 \text { primigestas } \\
\text { ( } 50 \text { intervenção e } 50 \\
\text { controle)/Uso da cola adesiva } \\
\text { cirúrgica Dermabond } ₫ \text { e fio de } \\
\text { sutura Vicryl Rapide } \AA \text { no reparo } \\
\text { da pele em episiotomias }\end{array}$ & $\begin{array}{l}\text { Menor tempo de reparo, menor } \\
\text { dor antes e durante o } \\
\text { procedimento da cola adesiva em } \\
\text { relação ao fio de sutura. } \\
\text { Cicatrização similar. }\end{array}$ \\
\hline $\begin{array}{l}\text { Feigenberg } \\
\text { et al. } \\
2014\end{array}$ & $\begin{array}{l}\text { Avaliar a eficácia da } \\
\text { cola adesiva } \\
\text { cirúrgica no reparo } \\
\text { de lacerações de } \\
\text { primeiro grau }\end{array}$ & $\begin{array}{l}\text { Ensaio clínico controlado e } \\
\text { randomizado/102 mulheres ( } 28 \\
\text { controle e } 74 \text { intervenção)/Uso } \\
\text { da cola adesiva cirúrgica } \\
\text { Dermabond® e fio de sutura } \\
\text { Vicryl Rapide® no reparo de } \\
\text { lacerações de primeiro grau }\end{array}$ & $\begin{array}{l}\text { A cola está associada a menor } \\
\text { tempo de procedimento, menor } \\
\text { utilização de anestésico local, } \\
\text { menor dor e maior satisfação. Em } \\
\text { relação ao resultado cosmético e } \\
\text { funcional, ambas as técnicas são } \\
\text { similares. }\end{array}$ \\
\hline $\begin{array}{l}\text { Mota et al. } \\
2009\end{array}$ & $\begin{array}{l}\text { Comparar o reparo } \\
\text { da pele em } \\
\text { episiotomias com } \\
\text { cola adesiva } \\
\text { cirúrgica e fio de } \\
\text { sutura poliglactina } \\
910 \text {, considerando a } \\
\text { incidência de dor e } \\
\text { complicações da } \\
\text { ferida }\end{array}$ & $\begin{array}{l}\text { Ensaio clínico controlado e } \\
\text { randomizado/100 mulheres ( } 53 \\
\text { controle e } 48 \text { intervenção)/Uso } \\
\text { da cola adesiva cirúrgica octyl-2- } \\
\text { cianoacrilato e fio de sutura } \\
\text { poliglactina } 910 \text { de rápida } \\
\text { absorção no reparo da pele em } \\
\text { episiotomias }\end{array}$ & $\begin{array}{l}\text { Menor tempo de reparo usando } \\
\text { cola adesiva cirúrgica. Em } \\
\text { relação à incidência de } \\
\text { complicação e dor nos primeiros } \\
30 \text { dias, ambas as técnicas são } \\
\text { similares. }\end{array}$ \\
\hline $\begin{array}{l}\text { Bowen e } \\
\text { Selinger } \\
2002 \\
\text { Reino } \\
\text { Unido }\end{array}$ & $\begin{array}{l}\text { Avaliar o reparo da } \\
\text { pele em episiotomias } \\
\text { com cola adesiva } \\
\text { cirúrgica } \\
\text { embucrilato e fio de } \\
\text { sutura de ácido } \\
\text { poliglicólico } \\
\end{array}$ & $\begin{array}{l}\text { Ensaio clínico controlado/62 } \\
\text { mulheres ( } 30 \text { controle e } 32 \\
\text { intervenção)/Uso da cola adesiva } \\
\text { cirúrgica embucrilato e fio de } \\
\text { sutura de ácido poliglicólico no } \\
\text { reparo da pele em episiotomias }\end{array}$ & $\begin{array}{l}\text { Mulheres submetidas à cola } \\
\text { adesiva cirúrgica tiveram menor } \\
\text { dor pós-parto enquanto } \\
\text { caminham, ficam sem dor em um } \\
\text { período menor e ficaram livres } \\
\text { de dor na relação sexual mais } \\
\text { cedo. }\end{array}$ \\
\hline $\begin{array}{l}\text { Rogerson, } \\
\text { Mason e } \\
\text { Roberts } \\
2000 \\
\text { Reino } \\
\text { Unido }\end{array}$ & $\begin{array}{l}\text { Avaliar o uso da } \\
\text { cola adesiva } \\
\text { cirúrgica Indermil@ } \\
\text { para o reparo } \\
\text { perineal }\end{array}$ & $\begin{array}{l}\text { Estudo prospectivo / } 20 \\
\text { mulheres/Uso da cola adesiva } \\
\text { cirúrgica Indermil@ no reparo da } \\
\text { pele em episiotomias e } \\
\text { lacerações de segundo grau }\end{array}$ & $\begin{array}{l}\text { Duas mulheres referiram } \\
\text { sensação de queimação durante a } \\
\text { aplicação; } 13 \text { mulheres não } \\
\text { tiveram problemas e duas } \\
\text { relataram sentir a ponta afiada da } \\
\text { cola; } 2 \text { tiveram pequenos defeitos } \\
\text { de aposição de pele com boa } \\
\text { cicatrização e duas tiveram a cola } \\
\text { completamente solta antes do } \\
\text { fechamento, entretanto sem } \\
\text { necessidade de ressutura. }\end{array}$ \\
\hline $\begin{array}{l}\text { Adoni e } \\
\text { Anteby } \\
1991 \\
\text { Jerusalém }\end{array}$ & $\begin{array}{l}\text { Verificar se a cola } \\
\text { adesiva cirúrgica } \\
\text { quando aplicada na } \\
\text { pele no lugar de } \\
\text { sutura reduz a dor e } \\
\text { desconforto } \\
\text { originada por } \\
\text { episiotomia médio- } \\
\text { lateral durante as } \\
\text { atividades diárias }\end{array}$ & $\begin{array}{l}\text { Estudo prospectivo/60 mulheres } \\
\text { ( } 20 \text { com reparo da primeira } \\
\text { episiotomia com sutura contínua } \\
\text { com categute cromado, } 20 \text { com } \\
\text { reparo da episiotomia de } \\
\text { repetição com sutura contínua } \\
\text { com categute cromado e } 20 \text { com } \\
\text { primeira episiotomia com cola } \\
\text { adesiva cirúrgica Hystoacril@ } \\
\text { para o reparo da pele }\end{array}$ & $\begin{array}{l}\text { O uso da cola cirúrgica } \\
\text { Hystoacril no reparo da pele em } \\
\text { episiotomias reduziu dor e } \\
\text { desconforto em atividades } \\
\text { diárias. }\end{array}$ \\
\hline
\end{tabular}


Além dos estudos apresentados, uma revisão sistemática comparou os métodos da não-sutura de colas adesivas cirúrgicas na pele e da sutura perineal no parto e concluiu que o uso de não-sutura ou de colas adesivas na pele é melhor em termos de redução da dor perineal; entretanto, o método de não-sutura associa-se a maiores taxas de separação da pele em curto prazo. Os autores da revisão sugerem que se realizem novos estudos com acompanhamento das mulheres com cola adesiva cirúrgica e não-sutura até os 6 meses pósparto para verificar também os resultados estéticos (Seijmonsbergen-Schermers et al., 2015).

\subsubsection{A ação da cola adesiva cirúrgica e seus subtipos}

As colas adesivas cirúrgicas de cianoacrilato são compostas por monômeros líquidos de baixa densidade, que se polimerizam através de uma reação exotérmica em contato com as superfícies de tecido biológico, criando uma camada forte e flexível que une mecanicamente as bordas das feridas (Andrade et al., 2001).

A adesão da cola adesiva cirúrgica aos tecidos ocorre por penetração da película monomérica através da atração eletroestática, ponte de hidrogênio, atração das massas ou força de Van Walls. Deste modo, a cola se ajusta aos padrões biológicos dos tecidos (Schmeissner, 1970 apud García Cerdá et al., 2015).

A partir do momento em que há a adesão das bordas, é promovida uma hemostasia local e selamento desta lesão, o que evita a contaminação externa. Devido à sua praticidade, rapidez e fácil manuseio, os adesivos cirúrgicos são indicados também para áreas delicadas, com difícil acesso por sutura ou grampeamento.

A degradação do cianoacrilato ocorre por hidrólise e a velocidade da mesma depende da quantidade de cadeia de alquilos na sua formulação. Cadeias menores tendem a se degradarem mais rapidamente, enquanto cadeias maiores podem demorar meses ou até anos (Pani et al., 1968 apud García Cerdá et al., 2015). Este fato pode ser utilizado como determinante para verificar qual o melhor tipo de cola para cada tipo de lesão, de acordo com o tempo de cicatrização dos diferentes tipos de tecidos.

No início da síntese dos cianoacrilatos houve um atraso na sua utilização clínica devido ao seu alto potencial de desenvolver uma reação inflamatória e citotoxidade, que foram diminuindo conforme o avanço nas suas formulações e o aumento de suas cadeias de 
alquilo. A toxicidade ocorre através de suas cadeias de alquilo, que se degradam em cianoacetato e formaldeído, impedindo sua metabolização e eliminação rápida; o resultado dessa ação é o acúmulo dessas substâncias no tecido, causando inflamação local (García Cerdá et al., 2015).

Para reduzir a toxicidade dos cianoacrilatos e possibilitar seu uso clínico, foram realizadas alterações, substituindo o radical metil por etil, butil, hexil ou dexil (Fischl, 1962). Essas alterações, apesar de diminuírem a toxicidade do produto, diminuíram sua propriedade adesiva (Papatheofanis, Barmada, 1993).

No mercado, existem vários tipos de cianoacrilatos, que divergem de acordo com as cadeias laterais de carbono e as do grupo alquilo, podendo ser identificadas como etil, metil, isobutil, butil e octil-2-cianoacrilato, de acordo com a cadeia de alquilo variável. As cadeias de alquilo mais curtas estão associadas com uma maior reatividade do composto e fixação mais rápida, porém tendem a criar uma superfície mais rígida e frágil, em comparação a cadeias mais longas (García Cerdá et al., 2015).

No Brasil, as colas ou adesivos cirúrgicos existentes são subdivididos entre os de uso externo e de uso interno, conforme sua formulação e segurança ${ }^{1}$. A única cola cirúrgica de uso interno e externo é o n-butil-2-cianoacrilato, sob o nome comercial de Glubran-2®. Sua formulação permite que a cola seja utilizada no leito da ferida em diversos procedimentos, como cirurgias cardíacas, vasculares, neurológicas, ginecológicas, radiologia, entre outras. O Histoacryl® também é um n-butil-2-cianoacrilato e possui duas formulações, uma para uso externo (Histoacryl Flexible®), com aplicação no fechamento de feridas cutâneas, e a Histoacryl® comum, também à base de n-butil-2-cianoacrilato, porém com outros estabilizadores em sua fórmula, permitindo seu uso em feridas cutâneas, escleroterapia de grandes varizes esofágicas ou fundo-gástricas e fixação de material de reforço em tecido mole. No entanto, o fabricante contraindica seu uso na união de órgãos internos, assim como em superfícies do sistema nervoso, devido à possibilidade de causar danos.

Os adesivos existentes apenas para uso externo, além do Histoacryl Flexible ${ }$, são o Dermabond® e o Epiglu®. O Dermabond® é um octil-2-cianoacrilato indicado para o uso tópico cutâneo em incisões cirúrgicas e pequenas lacerações, desde que bem limpas. O

\footnotetext{
${ }^{1}$ As especificações de cada adesivo cirúrgico apresentadas nesse item foram obtidas da ficha técnica do respectivo fabricante ou distribuidor.
} 
fabricante alerta que o adesivo Dermabond ${ }^{\circledR}$ não constitui um substituto de suturas subcutâneas, além de contraindicar seu uso em mucosas ou união muco-cutâneas ou sobre zonas que estejam expostas regularmente a fluidos corporais ou coberta por pilosidade natural densa.

O Epiglu® é um adesivo cirúrgico composto por etil-2-cianoacrilato, com indicação para o uso externo, em incisões cirúrgicas e lacerações recentes, em pele, mucosas e uniões muco-cutâneas (cavidade bucal e vaginal) e no pós-operatório. É utilizado como substituto de suturas em lesões, após a aproximação das bordas ou como suporte para suturas tradicionais.

O adesivo cirúrgico etil-2-cianoacrilato, assim como outros adesivos de utilização externa, deve ser utilizado nas bordas da ferida, após sua aproximação com as mãos ou instrumentos, ou seja, o adesivo deve ser utilizado de modo que cubra a lesão sem adentrar na mesma. Esse procedimento promove um efeito hemostático, uma vez que há a aposição dos tecidos, além de facilitar sua cura.

Para a utilização nesta pesquisa, foi selecionado o etil-2-cianoacrilato, sob o nome comercial de Epiglu®, pois é o único de uso externo no mercado brasileiro indicado para utilização em mucosas e união muco-cutâneas, características das lacerações perineais de primeiro grau, incluindo a região vulvar e a parede vaginal. Além disso, sua cadeia mais curta de alquilo promove uma degradação por hidrólise mais rápida, o que se justifica pela natureza da lesão, apesar de sua maior fragilidade em comparação aos adesivos externos com cadeias maiores, que têm o uso em mucosas contraindicado.

O Quadro 2 sintetiza todas as colas e adesivos cirúrgicos comercializados no Brasil, com informações sobre seus respectivos fabricantes, país de fabricação, princípios ativos, aplicações e reações adversas. 
Quadro 2- Colas adesivas cirúrgicas disponíveis no mercado brasileiro

\begin{tabular}{|l|l|l|l|l|l|}
\hline Nome comercial & Laboratório & País & Princípio ativo & Aplicação & $\begin{array}{l}\text { Reações } \\
\text { adversas }\end{array}$ \\
\hline Dermabond® & Ethicon & $\begin{array}{l}\text { Estados } \\
\text { Unidos da } \\
\text { América }\end{array}$ & 2octilcianoacrilato & $\begin{array}{l}\text { Externo: } \\
\text { pele }\end{array}$ & $\begin{array}{l}\text { Inflamação } \\
\text { aguda; } \\
\text { deiscência }\end{array}$ \\
\hline Epliglu® & MeyerHaake & Alemanha & etil-2cianoacrilato & $\begin{array}{l}\text { Externo: } \\
\text { pele e } \\
\text { mucosa }\end{array}$ & $\begin{array}{l}\text { Leve } \\
\text { aquecimento } \\
\text { local; reação } \\
\text { alérgica }\end{array}$ \\
\hline Glubran-2® & GEM & Itália & $\begin{array}{l}\text { n-butil- } \\
\text { 2cianoacrilato }\end{array}$ & $\begin{array}{l}\text { Interno e } \\
\text { externo }\end{array}$ & $\begin{array}{l}\text { Reação } \\
\text { inflamatória; } \\
\text { sensação de } \\
\text { calor }\end{array}$ \\
\hline Histoacryl® & B Braun & Espanha & $\begin{array}{l}\text { n-butil- } \\
\text { 2cianoacrilato }\end{array}$ & $\begin{array}{l}\text { Interno e } \\
\text { externo }\end{array}$ & $\begin{array}{l}\text { Danos } \\
\text { térmicos ao } \\
\text { tecido; } \\
\text { irritação } \\
\text { local; reação } \\
\text { inflamatória }\end{array}$ \\
\hline
\end{tabular}

\subsection{DOR PERINEAL}

A dor é um dos sintomas mais importantes e comumente relatados na ocorrência de um trauma perineal e pode ser responsável por limitar a recuperação pós-parto e a capacidade da mulher em executar suas atividades cotidianas (Ismail et al, 2013; Thakar, Sultan, 2009). Um inquérito realizado nos Estados Unidos da América, com um total de 1.573 mulheres no pós-parto, apresentou prevalência elevada dor perineal em $77 \%$ das primíparas e $52 \%$ das multíparas após parto vaginal (Declercq et al, 2008).

A percepção da dor é um processo complexo que envolve uma gama de atividades nervosas, que são moduladas através de alterações hormonais, sensoriais, de memórias e experiências passadas (Eshkevari, Trout, Damore, 2013). A forma com que a mulher é preparada para lidar com a dor no período do trabalho de parto e pós-parto, junto com a percepção que esta teve sobre os cuidados recebidos, pode tornar a dor referida de maior ou menor intensidade (Trout, 2004). 
O dano tecidual provocado no períneo durante o parto, mesmo no caso de períneo íntegro, resulta na liberação de mediadores inflamatórios que contribuem para o aumento da sensação dolorosa. A sensação dolorosa irá depender, dentre outros fatores, do grau de laceração perineal e do material e técnica utilizados para seu reparo, pois desencadearão mediadores inflamatórios em maior quantidade a depender destes fatores (Trout, 2005; Frohlich, Kettle, 2015).

É importante que no relato de dor no período do pós-parto, o profissional responsável pelo atendimento realize uma avaliação cuidadosa. Identificar localização, início, duração, tipo, tempo e intensidade da dor são essenciais para estabelecer um plano de cuidado adequado e evitar complicações, caso a dor esteja exacerbada ou incomum.

A dor aguda pode provocar alterações no padrão de sono, apetite, libido, manifestações de irritabilidade, menor concentração, restrições de atividades físicas, profissionais e sociais (Kreling, da Cruz, Pimenta, 2006). Sendo assim, medidas que promovam a diminuição da dor no puerpério e facilitem a cicatrização podem contribuir para o bem-estar físico e psicológico das mulheres.

A dor referida no trauma perineal pode ser alterada devido a morbidades como complicações na cicatrização, provocando hiperemia, edema, equimose, secreção e não coaptação da ferida. É preciso mensurar a dor para que haja a possibilidade de encontrar novos tratamentos que promovam sua diminuição.

Existem alguns instrumentos de medida da dor de acordo com diferentes parâmetros, cada um possui sua peculiaridade e é de extrema importância que o instrumento afira a dor em si e não outras características que possam confundir com a sensação dolorosa.

Os instrumentos podem se basear em medidas fisiológicas, observacionais ou autorreferidas. As medidas fisiológicas são as respostas biológicas à dor, representadas por frequência cardíaca, respiratória e tensão muscular, por exemplo. Geralmente, este método de mensuração da dor é aplicado em indivíduos que não conseguem relatar a dor verbalmente. O método observacional também pode ser utilizado para esses indivíduos, entretanto, nesse método a avaliação da dor é verificada por um profissional que observa as alterações do comportamento do indivíduo que podem estar associadas à dor; esse método é mais subjetivo e de alto custo, visto a necessidade de um profissional todo tempo para observação (Strong et al., 2001). 
A dor autorreferida é considerada padrão ouro entre as medidas de avaliação da dor, uma vez que o indivíduo que vivencia a dor é o mesmo que a referencia e, para isso, é necessário que o indivíduo esteja em condições de responder às perguntas necessárias. Esse tipo de avaliação pode ser realizado através de escalas e questionários. Atualmente, são validadas e bastante utilizadas a Escala Visual Analógica (EVA), Escala Visual Numérica (EVN) e questionário de McGill (Strong et al., 2001).

É importante que a escala escolhida esteja de acordo com o grau de desenvolvimento do indivíduo e seu estado cognitivo. A escala multidimensional mais utilizada e testada é o questionário de McGill e seu preenchimento leva de 5 a 15 minutos; é o mais extenso inventário de dor disponível e requer maior interpretação do paciente. Sua utilização em adultos é considerada eficaz e reprodutível, entretanto, a eficácia varia de acordo com a disfunção cognitiva do indivíduo (Twaddle, Cooke, 2011).

A EVA também possui fácil compreensão, requer que o indivíduo possa visualizar o instrumento e a graduação numérica pode ser dada de acordo com o nível da dor. É considerada um meio eficaz de mensuração, entretanto, cerca de $10 \%$ dos adultos ficam confusos com o teste. Em relação à EVN, geralmente, é bem compreendida e aceita; pode ser escrita ou oral. Não é considerada uma escala apropriada para crianças, tendo em vista que estas podem ser incapazes de utilizá-la. Para adultos, é considerada eficaz e, assim como as outras escalas, a eficácia dependerá do grau de disfunção cognitiva do indivíduo que autorrefere a dor (Twaddle, Cooke, 2011).

Para este estudo, foi selecionada a EVN, uma vez que é uma escala validada, eficaz para os adultos, de fácil e rápida execução e que se assemelha aos outros estudos sobre reparo perineal, tornando factível a comparação entre estes.

\subsection{CICATRIZAÇÃO PERINEAL}

A cicatrização dos traumas perineais dependerá da característica de cada lesão e ocorre por meio da regulação de uma série de reações bioquímicas sequencias, sobrepostas e interdependentes altamente complexas. É um processo dinâmico, regulado por mecanismos celulares, hormonais e moleculares que se inicia imediatamente após a ferida abrir e pode durar anos (Reinke, Sorg, 2012.) 
Alguns fatores prejudicam a cicatrização perineal e é essencial que sejam corrigidos naquelas mulheres em que há um retardo ou deficiência na cicatrização. Dietas inadequadas, estresse, ansiedade, obesidade, idade, distúrbios patológicos, infecção, tabagismo e determinadas drogas podem influenciar negativamente o reparo adequado (Steen, 2007).

O processo de cicatrização pode ser classificado por primeira intenção, quando as bordas da ferida são aproximadas por algum meio de reparo (sutura ou cola, por exemplo). Nesse caso, a intenção é a de que toda a extensão das bordas se aproxime e não seja criado tecido de granulação, ou que este seja mínimo (Boyle, 2006).

Cicatrização por segunda intenção ocorre quando há alguma perda de tecido ou espaço morto entre as bordas; portanto, há o crescimento de tecido de granulação nesse espaço. Após a granulação preencher completamente o espaço, a área se contrai gradualmente a fim de aproximar as bordas. Esse processo pode ser mais demorado e tem uma taxa maior de complicações de feridas (Boyle, 2006; Steen, 2007).

Quando a ferida é deixada aberta para permitir que o edema ou exsudado drene antes do reparo primário, é considerada uma cicatrização por terceira intenção (Boyle, 2006; Steen, 2007). Ou seja, após alguns dias aguardando a drenagem da ferida, é realizado um desbridamento e fechamento cirúrgico (Vuolo, 2006).

As fases do processo de cicatrização podem ser descritas em hemostasia, fase inflamatória, de proliferação e de remodelação (Steen, 2007).

Como exposto anteriormente, o dano tecidual causado no períneo durante o parto vaginal inicia processos inflamatórios, ativando a liberação de citocinas, células e elementos celulares, além de mediadores químicos. Esse processo faz com que os vasos rompidos iniciem uma resposta de emergência para formação de coágulos, através da migração de plaquetas e fatores de coagulação; assim, é desenvolvido um coágulo de fibrina que promove hemostase (Li, Chen, Kirsner, 2007; Steen, 2007). Concomitante a esse processo, ocorre uma vasoconstrição que interrompe o sangramento excessivo destes vasos, auxiliando na diminuição do sangramento e, portanto, na estabilização dos coágulos. A esse processo denominamos fase de hemostasia.

A partir do momento em que o coágulo de fibrina é estabilizado, inicia-se a sua decomposição através da plasmina. Esse processo inicia a liberação de histamina e serotonina, promovendo a vasodilatação e aumento da permeabilidade capilar (Steen, 2007). 
A resposta inflamatória ocorre após o parto e pode durar de 5 a 7 dias (Boyle, 2006). Essa fase pode se tornar prolongada, caso a ferida esteja infectada ou com a presença de material de sutura (Steen, 2007).

A fase inflamatória é um importante mecanismo de defesa do corpo e essencial durante o processo de cicatrização. Os sinais correspondentes à inflamação são rubor, calor, edema, dor e perda da função. A vasodilatação que ocorre nessa fase promove o acúmulo sanguíneo na região lesada, causando rubor e calor local junto às reações metabólicas. Esse processo de dilatação dos vasos é essencial para o recrutamento de neutrófilos e monócitos no leito da ferida, devido à maior permeabilidade dos mesmos. Concomitante a isto, ocorre o extravasamento de fluidos ao redor da ferida, provocando edema local (Steen, 2007).

O recrutamento de leucócitos, majoritariamente neutrófilos, realizará a destruição de bactérias e corpos estranhos. Uma vez que há a diminuição dos leucócitos, inicia-se a ação dos macrófagos, que contribuirão para manutenção da limpeza da ferida e na produção de fatores de crescimento, citocinas e prostaglandinas, os quais, por sua vez, atrairão as células necessárias para angiogênese e formação importante de colágeno. Essa fase promoverá a produção de exsudato (leucócitos, eritrócitos, plaquetas, proteínas plasmáticas e anticorpos), podendo aumentar o edema, porém como parte natural do processo de cicatrização (Boyle, 2006; Steen, 2007).

Todos os processos e sinais correspondentes à inflamação são importantes à cicatrização, entretanto, a exacerbação ou diminuição destes pode indicar infecção ou isquemia da ferida (Oldfield, 2010). Os macrófagos recrutados na fase inflamatória serão essenciais para fase proliferativa (Steen, 2007).

A fase proliferativa é o processo de reparo dos tecidos através de células de substituição. Nessa fase, estão contidos os processos de granulação (angiogênese e matriz de colágeno), contração (minimiza o tamanho da ferida) e epitelização (regenera o epitélio).

O processo de granulação envolve a criação de uma nova rede de vasos sanguíneos e matriz de colágeno (Li, Chen, Kirsner, 2007; Steen, 2007). Os fatores de crescimento angiogênico são secretados pelos macrófagos em ambiente hipóxico; eles contribuirão para o crescimento de novos vasos. Os vasos que não estão danificados ao redor da ferida se unem aos novos vasos. O aumento dos macrófagos atrai fibroblastos que produzem proteínas para estabilizar a força do novo tecido, criando uma matriz de colágeno ao redor dos novos vasos 
(Boyle, 2006). O tecido de granulação, visualmente, tem característica vermelho brilhante, úmido e é um bom indicador de processo de cura da ferida (Flanagan, 1996). À medida que o novo tecido e nova rede vascular são criados, os macrófagos e fibroblastos declinam de maneira proporcional (Steen, 2007).

Por vezes, o tecido de granulação pode crescer de modo acentuado e ir além dos limites da ferida, necessitando de reparo, em alguns casos. O processo de contração ocorre após a produção de um tecido de granulação saudável e é o responsável por minimizar o tamanho da ferida; seu início começa por volta do $5^{\circ}$ ao $6^{\circ}$ dia (Steen, 2007). Nos tecidos cicatrizados por primeira intenção, esse processo ocorre de maneira muito sutil, pois requer pouca migração celular e tecido de granulação, uma vez que não há grande espaço a preencher, já que são aproximados artificialmente (Boyle, 2006).

O processo de epitelização inicia-se após o tecido de granulação se formar. As novas células epiteliais originam-se das bordas da ferida e migram ao longo do tecido de granulação, até formarem uma camada contínua de células e fechar a ferida por completo $O$ tecido de epitelização, visualmente, tem característica esbranquiçada e pode aparecer junto com o tecido de granulação, no momento em que está se desenvolvendo (Flanagan, 1996).

Por fim, a fase de remodelação é responsável pela reorganização da ferida. Nessa fase, há uma diminuição da atividade celular e a ferida se torna menos vascularizada. A rede de colágeno, inicialmente instituída, é substituída por uma rede mais forte e altamente organizada (Boyle, 2006). A cicatriz, que inicialmente é proeminente, começa a aproximarse mais do nível do tecido ao seu redor e a resistência à tração aumenta gradualmente. Durante essa fase, pode ocorrer contração da cicatriz, a qual, dependendo do local, pode causar desconforto e restringir os movimentos. Esse processo pode demorar até um ano em feridas fechadas e um pouco mais nas abertas (Steen, 2007).

O presente estudo visa analisar duas técnicas de reparo através de cicatrização por primeira intenção, uma vez que, independentemente do tipo de material ou técnica utilizada, os traumas perineais serão reparados por meios externos. 


\subsection{JUSTIFICATIVA}

De acordo com a literatura existente, são necessárias mais pesquisas bem desenhadas para analisar a efetividade e a superioridade das colas adesivas cirúrgicas em relação à sutura do trauma perineal no parto, uma vez que os desfechos se mostram positivos em diversos aspectos. Assim, novos estudos podem trazer conclusões com base em evidências robustas.

Portanto, é interessante que seja realizado um estudo para analisar o uso dessa técnica, visando à redução de morbidade relacionada à recuperação perineal no pós-parto. 
2 HIPÓTESE 


\section{HIPÓTESE CONCEITUAL}

O uso da cola adesiva cirúrgica no reparo de lacerações perineais de primeiro grau decorrentes do parto normal promove reparo rápido, menos dor perineal em relação à sutura com fio, cicatrização adequada e satisfação da mulher. 
3 OBJETIVOS 


\section{OBJETIVOS}

\subsection{GERAL}

Determinar a viabilidade de se realizar um ensaio clínico controlado e aleatorizado, com a finalidade de avaliar a efetividade da cola adesiva cirúrgica no reparo das lacerações perineais de primeiro grau decorrentes do parto normal.

\subsection{ESPECÍFICOS}

- Comparar a intensidade da dor perineal em mulheres submetidas ao reparo com cola adesiva cirúrgica e sutura com fio.

- Comparar o tempo de reparo das lacerações perineais de primeiro grau com cola adesiva cirúrgica e sutura com fio.

- Comparar o processo de cicatrização das lacerações perineais de primeiro grau com cola adesiva cirúrgica e sutura com fio.

- Comparar a satisfação da mulher com o uso da cola adesiva cirúrgica e da sutura com fio. 
4 MÉTODO 


\section{MÉTODO}

\subsection{DESENHO}

Trata-se de um estudo piloto paralelo, controlado e aleatorizado, comparando o reparo perineal com o adesivo cirúrgico Epiglu ${ }^{\circledR}$ e com o fio de sutura Vicryl Rapide ${ }^{\circledR}$ em mulheres com lacerações perineais de primeiro grau no parto normal.

\subsection{LOCAL}

O estudo foi realizado no Centro de Parto Normal (CPN) do Pronto Socorro e Maternidade Municipal Zoraide Eva das Dores (PSMMZED), em Itapecerica da Serra, região de domicílio das mulheres que compuseram a amostra do estudo.

O município de Itapecerica da Serra pertence à microrregião de Itapecerica da Serra, composta por oito municípios, e localiza-se na zona sudoeste da Região Metropolitana de São Paulo. Segundo o Censo do Instituto Brasileiro de Geografia e Estatística (IBGE) de 2010, a população é de 152.380 habitantes, distribuída em uma área de 151.458 km².

Itapecerica da Serra dispõe de duas maternidades públicas, integradas ao Sistema Único de Saúde. O PSMMZED, reinaugurado em setembro de 2004, é administrado pela Autarquia Municipal de Saúde (AMS), responsável por aproximadamente 380 atendimentos por dia, nas especialidades de clínica geral, obstetrícia, ginecologia e pediatria.

A maternidade do PSMMZED é referência para gestantes de risco habitual também dos municípios de Embu-Guaçu, Juquitiba e São Lourenço da Serra e atende cerca de 120 a 130 partos por mês. Funciona como CPN e o espaço físico é composto por duas salas de préparto, com dois leitos cada, e duas salas de parto. Possui, ainda, duas salas de cirurgia e 17 leitos de alojamento conjunto (AC). $\mathrm{O}$ atendimento às mulheres em trabalho de parto e parto é realizado por uma equipe composta, por turno, por duas enfermeiras obstétricas, dois médicos obstetras, um médico anestesista e um médico neonatologista, além de técnicos e auxiliares de enfermagem e quatro voluntárias que auxiliam a equipe no acolhimento das gestantes. 
Conforme os registros do livro de partos, em 2015, a média mensal de atendimentos foi de 135 partos, dos quais, 73,7\% corresponderam a partos vaginais e 26,3\% a cesarianas. Dentre as mulheres com partos vaginais, 35,2\% tiveram períneo íntegro, 31,9\% tiveram lacerações perineais de primeiro grau, 19,1\% tiveram lacerações de segundo grau e 13,7\% foram submetidas à episiotomia.

\subsection{POPULAÇÃO E AMOSTRA}

A população foi composta por mulheres atendidas no PSMMZED que apresentaram lacerações perineais de primeiro grau com indicação de sutura. Foram elegíveis todas as mulheres internadas no CPN durante o período em que a pesquisadora esteve presente para coleta de dados.

\subsubsection{Critérios de inclusão}

As mulheres que atenderam aos seguintes critérios de inclusão foram convidadas a participar do estudo após a internação no CPN:

-Ter até $6 \mathrm{~cm}$ de dilatação cervical no momento em que foi convidada a participar da pesquisa;

•Não fazer uso de substâncias esteroides;

•Não apresentar leucorréia ou qualquer sinal de infecção no local de reparo;

-Sem diagnóstico de diabetes mellitus;

-Sem histórico de alergia à cola adesiva cirúrgica ou ao formaldeído;

-Sem dificuldade no entendimento do idioma português ou na comunicação;

-Aceitar ser submetida aos métodos de reparo perineal com cola adesiva cirúrgica ou fio de sutura. 


\subsubsection{Critérios de exclusão}

-Não ter parto normal;

-Ter laceração de primeiro grau sem indicação de sutura, segundo critério do profissional responsável pelo atendimento ao parto;

-Ter episiotomia ou laceração de segundo, terceiro ou quarto graus concomitantes à laceração de primeiro grau;

-Apresentar fisometria;

-Apresentar varizes vulvares;

-Ter complicações decorrentes do parto ou pós-parto que exigiram transferência hospitalar da mulher para um hospital de alta complexidade.

\subsubsection{Tamanho da amostra}

Por tratar-se de um estudo piloto, 20 mulheres foram incluídas na amostra para que se pudesse observar a diferença de médias e desvios-padrão entre os grupos e, assim, calcular o número de participantes necessárias para que haja diferença estatisticamente significante com erro do tipo I de $5 \%$ e poder de teste de $95 \%$ em um futuro ensaio clínico.

As mulheres da amostra foram distribuídas em um grupo experimental (GE) (n=10) e controle (GC) $(n=10)$. O GE foi constituído por mulheres submetidas ao reparo perineal das lacerações com o adesivo cirúrgico etil-2-cianoacrilato, sob o nome comercial Epiglu®. O GC foi constituído por mulheres submetidas ao reparo perineal por sutura com o fio poliglactina 910, sob o nome comercial Vicryl Rapide®.

\subsubsection{Aleatorização}

A alocação das mulheres nos dois grupos de estudo ocorreu de forma aleatorizada, por meio de uma tabela de números aleatórios produzidos eletronicamente pelo programa estatístico R versão 3.4.2. Os números foram alocados em envelopes opacos, abertos somente no momento do reparo perineal, contendo em qual grupo a mulher deveria ser alocada. 


\subsection{EXPOSIÇÃO E DESFECHOS}

A exposição são as técnicas de reparo de lacerações perineais de primeiro grau com cola adesiva cirúrgica e com fio de sutura.

O desfecho primário é a intensidade da dor perineal após o parto. Os desfechos secundários são o processo de cicatrização, a satisfação da mulher com reparo perineal e o tempo dispendido pelo profissional para o reparo perineal.

\subsection{INTERVENÇÃO}

\subsubsection{Reparo da laceração perineal com cola adesiva cirúrgica}

A cola adesiva cirúrgica com substância ativa etil-2-cianoacrilato tem indicação de uso externo em incisões cirúrgicas e lacerações recentes, em mucosas ou uniões mucocutâneas (cavidade bucal e vaginal) e no pós-operatório. É utilizado tanto como substituto como auxiliar às suturas nas lesões e tem efeito bacteriostático, selante e à prova d’água.

O adesivo Epiglu® é produzido pela empresa alemã Meyer-Haake e importado no Brasil pela empresa farmacêutica Midy Comércio Ltda., autorizada pela Agência Nacional de Vigilância Sanitária (Anvisa) sob o registro 8016417007.

O produto disponível no Brasil é o "Epiglu Single Dose”, o qual, em sua composição, possui etil-2-cianoacrilato (>75\%) e polimetilmetacrilato (2 a 5\%). Sua apresentação contém dose única de 0,3 mL cada. A dose permite aderir uma lesão de até $10 \mathrm{~cm}$ de comprimento e sua forma líquida tem rápida polimerização em contato com a água e fluidos corporais; portanto, quantidades mínimas são suficientes para garantir a adesão à superfície tratada.

O produto deve ser armazenado refrigerado a $-18^{\circ} \mathrm{C}$ e sua validade é de 24 meses; se armazenado em refrigerador, o período de validade reduz para 6 meses. A recomendação do fabricante é a de que o produto seja transportado em temperatura variando entre $15^{\circ} \mathrm{Ce} 30^{\circ} \mathrm{C}$, por no máximo 72 horas. Seguem abaixo os passos seguidos para o reparo com a cola adesiva:

1.Colocar a mulher na posição ginecológica, com a região genital desnuda e fotografar a região;

2.Calçar luvas estéreis; 
3.Avaliar as condições do períneo e confirmar o grau de laceração informado pela enfermeira responsável pelo atendimento ao parto;

4.Se necessário, introduzir um chumaço de gazes no introito vaginal para impedir a saída de sangue e manter a região do trauma perineal mais seca;

5.Secar com gazes a região onde será feito o reparo perineal;

6.Solicitar a abertura da embalagem em pétala, no local indicado, e retirar o flaconete de Epiglu® dose única;

7.Segurar a parte inferior do flaconete e girar a parte superior, retirando-a;

8.Retirar o dispensador e fixar na ponta superior do flaconete;

9.Aproximar as bordas da lesão com o dedo polegar e indicador;

10.Segurar o flaconete aberto e voltado para baixo, apertando-o levemente, enquanto aplica-se uma a duas gotas da solução de Epiglu®;

11.Espalhar a solução em uma camada fina, utilizando a curva do dispensador;

12. Verificar se o reparo está adequado e aplicar mais cola adesiva nas regiões em que a aproximação não estiver adequada. Atentar para aplicar a menor quantidade de cola possível, pois promove uma melhor adesão;

13.Fotografar a área reparada;

14.Deixar a mulher em uma posição confortável e coberta.

\subsubsection{Reparo da laceração perineal com fio de sutura}

O reparo convencional foi realizado por meio de sutura com fio de poliglactina 910 de rápida absorção (Vicryl Rapide®). Esse fio é composto por glicólida em $90 \%$ e lactida em $10 \%$, com a cobertura composta por $50 \%$ de poliglactina 370 e $50 \%$ de estearato de cálcio. É trançado, incolor e esterilizado por Cobalto 60. Sua resistência tensil in vivo é de $100 \%$ no primeiro dia, $81 \%$ no terceiro, $57 \%$ no quinto, $53 \%$ no sétimo e $0 \%$ após 14 dias, a absorção completa ocorre em até 35 dias, por hidrólise. É fabricado pela Ethicon-Johnson\&Johnson.

Para a utilização no reparo perineal, foi utilizado o fio calibre 3-0, com 70 centímetros de comprimento e agulha 3/8, 26 milímetros. Abaixo seguem os passos utilizados para o reparo com a técnica do fio de sutura:

1.Colocar a mulher na posição ginecológica, com a região genital desnuda;

2.Calçar luvas estéreis; 
3.Avaliar as condições do períneo e confirmar o grau de laceração informado pela enfermeira responsável pelo atendimento ao parto;

4.Se necessário, introduzir um chumaço de gazes no introito vaginal para impedir a saída de sangue e manter a região da laceração perineal mais seca;

5.Secar com gazes a região onde será feito o reparo perineal;

6.Realizar anestesia local com lidocaína $1 \%$ sem vasoconstritor;

7.Realizar a sutura com fio Vicryl Rapide ${ }^{\circledR}$, com pontos contínuos sem ancorar;

8.Verificar se o reparo perineal está adequado;

9.Fotografar a região de reparo perineal;

10.Deixar a mulher em uma posição confortável e coberta.

\subsection{AVALIAÇÃO DOS DESFECHOS}

Dada a natureza das intervenções e dos desfechos, não houve possibilidade de ocorrer o cegamento. Tanto as mulheres como a pesquisadora tiveram ciência do tipo de reparo perineal. Na avaliação do processo de cicatrização, a observação do períneo expôs se houve reparo com fio de sutura ou cola adesiva cirúrgica.

\subsubsection{Intensidade da dor perineal}

Referente à intensidade da dor perineal, foi utilizada a Escala Visual Numérica (EVN) (Apêndice A) de tamanho $5 \mathrm{~cm} \times 20 \mathrm{~cm}$, apresentando números de zero a dez, em que zero representa ausência de dor e dez a pior dor possível. A avaliação foi realizada em duas horas, 12 a 24 horas, 36 a 48 horas e 10 a 20 dias pós-parto. A avaliação da intensidade da dor por meio de EVN é um parâmetro de alta qualidade para o planejamento da terapia antálgica (Hjermstad et al, 2011).

\subsubsection{Processo de cicatrização}

O processo de cicatrização foi avaliado por meio da Escala REEDA (Figura 1) (hiperemia, edema, equimose, secreção e coaptação) (Hill, 1990). Para avaliação destes parâmetros foi utilizada uma régua específica para avaliação de laceração perineal, a PeriRule® (Figura 2) (Metcalfe, 2002), higienizada com água, sabão e álcool 70\% a cada 
utilização e, em seguida, isolada com filme plástico, que foi descartado a cada uso. A avaliação foi realizada 12-24 horas, 36-48 horas e 10-20 dias. A escala é composta por cinco itens, para cada item avaliado pode ser atribuída a pontuação de 0 a 3 , alcançando no máximo 15 pontos na escala. A pontuação máxima de 15 corresponde à pior cicatrização do períneo.

Figura 1- Escala REEDA de avaliação da hiperemia, edema, equimose, secreção e coaptação de bordas da lesão

\begin{tabular}{|c|c|c|c|c|c|}
\hline Pontos & Hiperemia & Edema & Equimose & Secreção & Coaptação \\
\hline 0 & Nenhuma & Nenhum & Nenhuma & Nenhuma & Fechada \\
\hline 1 & $\begin{array}{l}\text { Até } 0,25 \mathrm{~cm} \text { da } \\
\text { incisão } \\
\text { bilateralmente }\end{array}$ & $\begin{array}{l}\text { Perineal a menos } \\
\text { de } 1 \mathrm{~cm} \text { a partir } \\
\text { da incisão }\end{array}$ & $\begin{array}{l}\text { Até } 0,25 \mathrm{~cm} \text { da } \\
\text { incisão } \\
\text { bilateralmente ou } \\
0,5 \mathrm{~cm} \\
\text { unilateralmente }\end{array}$ & Serosa & $\begin{array}{l}\text { Pele separada } \\
3 \mathrm{~mm} \text { ou menos }\end{array}$ \\
\hline 2 & $\begin{array}{l}\text { Até } 0,5 \mathrm{~cm} \text { da } \\
\text { incisão } \\
\text { bilateralmente }\end{array}$ & $\begin{array}{l}\text { Perineal ou } \\
\text { vulvar de } 1-2 \mathrm{~cm} \\
\text { da incisão }\end{array}$ & $\begin{array}{l}\text { Entre } 0,25 \mathrm{~cm} \mathrm{e} \\
1 \mathrm{~cm} \\
\text { bilateralmente } \\
\text { ou entre } 0,5-2 \mathrm{~cm} \\
\text { unilateralmente }\end{array}$ & Serosanguínea & $\begin{array}{l}\text { Pele e } \\
\text { subcutâneo } \\
\text { separados }\end{array}$ \\
\hline 3 & $\begin{array}{l}\text { Além de } 0,5 \mathrm{~cm} \\
\text { da incisão } \\
\text { bilateralmente }\end{array}$ & $\begin{array}{l}\text { Perineal ou } \\
\text { vulvar além de } \\
2 \mathrm{~cm} \text { da incisão }\end{array}$ & $\begin{array}{l}\text { Além de } 1 \mathrm{~cm} \\
\text { bilateralmente ou } \\
2 \mathrm{~cm} \\
\text { unilateralmente }\end{array}$ & $\begin{array}{l}\text { Sanguinolenta, } \\
\text { purulenta }\end{array}$ & $\begin{array}{l}\text { Pele, subcutâneo } \\
\text { e músculo } \\
\text { separados }\end{array}$ \\
\hline Escore & & & & & \\
\hline & & & & \multicolumn{2}{|l|}{ Total } \\
\hline
\end{tabular}


Figura 2- Peri- Rule®

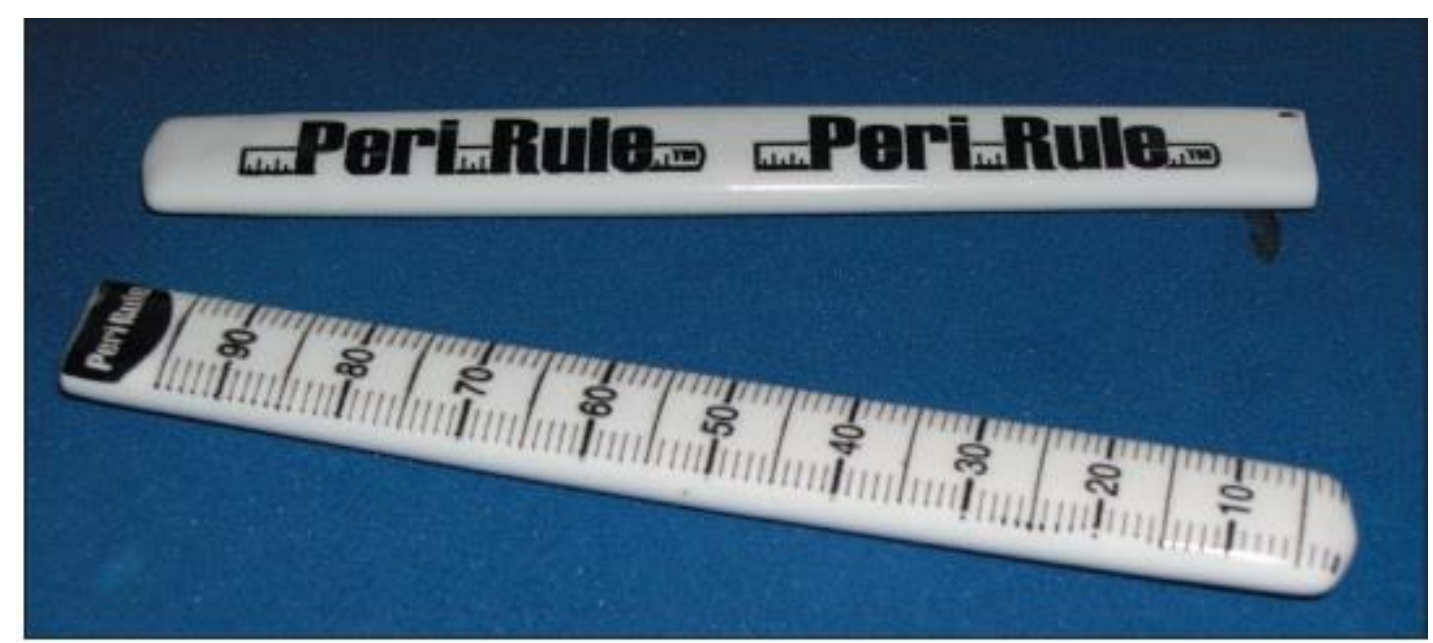

Fonte: Metcalfe (2004)

\subsubsection{Satisfação da mulher}

Para a análise deste desfecho, foi criada uma escala visual analógica (EVA) que foi apresentada às participantes da pesquisa em uma régua de tamanho $5 \mathrm{~cm}$ x $20 \mathrm{~cm}$ (Apêndice B), mostrando quatro faces com feições distintas representando a satisfação com o método utilizado, sendo atribuída a característica a "muito insatisfeita", "insatisfeita", "satisfeita" e "muito satisfeita", seguindo o sentido das feições da esquerda para direita. A avaliação foi realizada até 2 horas, 12-24 horas, 36-48 horas e 10-20 dias após o parto. Foi oferecido um espelho para que as mulheres que se sentissem à vontade pudessem visualizar o períneo e a estética do reparo, para que, dessa forma, pudessem complementar sua avaliação sobre a satisfação perineal.

\subsubsection{Tempo do reparo perineal}

O tempo foi registrado com auxílio de um cronômetro digital durante a realização do procedimento. $\mathrm{O}$ início da contagem inicial do tempo foi a partir do momento em que o profissional pegou o instrumental para começar o reparo, até o momento em que ele soltou o material e indicou a finalização, indicado como passo 4 do item 4.5 . 


\subsection{COLETA DE DADOS}

No local do estudo, foi realizada concomitantemente a pesquisa "Ensaio clínico sobre o uso de cola cirúrgica no reparo de episiotomias e lacerações perineais”, coordenada pela Professora Doutora Adriana de Souza Caroci, docente do Curso de Obstetrícia da EACHUSP, com a participação da orientadora desta dissertação. Essa pesquisa utilizou o adesivo cirúrgico Glubran-2® (n-butil-2-cianoacrilato) em episiotomias e lacerações de segundo grau. Os responsáveis técnicos pela referida pesquisa são o diretor técnico da AMS de Itapecerica da Serra (médico obstetra) e a coordenadora do projeto (enfermeira obstétrica).

Antes da coleta de dados, ambos os estudos foram apresentados aos profissionais do serviço, visando obter aceitação, colaboração e integração dos profissionais com as pesquisas. A colaboração foi voluntária e obteve aceitação de todos os profissionais do CPN.

Para o recrutamento das participantes, a pesquisadora frequentou o local de estudo diariamente, a fim de localizar as mulheres que se enquadravam aos critérios inclusão no estudo, até a finalização da amostra.

As mulheres que atenderam aos critérios de inclusão foram informadas sobre o estudo e convidadas a participar mediante leitura e assinatura do Termo de Consentimento Livre e Esclarecido (TCLE) para participantes com 18 anos ou mais (apêndice D) ou Termo de Assentimento (TA) para as menores de 18 anos (apêndice E) e TCLE para responsáveis pelas participantes com menos de 18 anos (Apêndice F).

Imediatamente após cada parto foi preenchido o formulário de registro dos dados elaborado, exclusivamente para este estudo (Apêndice C). Trata-se de um instrumento único, que foi utilizado também para o seguimento das mulheres ao longo do estudo.

O atendimento ao parto e a classificação do grau de laceração perineal foram realizados pelas enfermeiras obstétricas e médicos obstetras da instituição. Após esta avaliação foi confirmado o grau de laceração pela pesquisadora, que realizou, a seguir, o reparo perineal.

Foi solicitado aos profissionais que não prescrevessem analgésicos e antiinflamatórios de rotina, para que se pudesse avaliar melhor a intensidade da dor perineal das puérperas. Porém, os mesmos foram prescritos em casos de necessidade clínica ou em casos de solicitação das puérperas. As participantes foram orientadas a solicitar medicamentos para 
a dor a qualquer momento que sentissem necessidade. Além disso, foi planejada uma avaliação médica no caso de intercorrência com o reparo.

\subsubsection{Procedimento de coleta de dados}

Os dados foram coletados em quatro momentos diferentes.

-Etapa 1: corresponde à inclusão da mulher no estudo, alocação em um dos grupos, caracterização da laceração perineal, realização do reparo, cronometragem do tempo de reparo e avaliação dos desfechos no momento do reparo perineal, as mulheres foram entrevistadas até 2 horas após o parto. Antes e após a intervenção, foi tirada uma fotografia para registrar a laceração perineal e o reparo realizado. As fotos foram utilizadas com a finalidade de documentação do estudo. Os dados foram obtidos mediante consulta ao prontuário, entrevista com a mulher e exame perineal.

As etapas seguintes correspondem ao seguimento das mulheres ao longo do estudo, nos períodos pós-parto descritos a seguir.

-Etapa 2: realizada mediante entrevista e exame perineal, durante a internação no AC, 12 a 24 horas após o parto;

-Etapa 3: realizada mediante entrevista e exame perineal, durante a internação no AC, 36 a 48 horas após o parto. Nessa etapa, foi agendada a data da etapa seguinte;

-Etapa 4: realizada mediante entrevista e exame perineal, no PSMMZED ou no domicílio, conforme a preferência da mulher, 10 a 20 dias horas após o parto. A pesquisadora realizou contato telefônico com a participante uma semana, 2 dias antes e na data agendada para confirmar o comparecimento. Nessa etapa, também foi fotografada a região perineal com a finalidade de documentação.

\subsection{VARIÁVEIS}

\subsubsection{Variáveis dependentes}

-Intensidade da dor perineal - escore de dor autorreferida, segundo a EVN, com variação de 0 a 10 ;

-Tempo dispendido pelo profissional para o reparo perineal - em minutos; 
-Satisfação da mulher com o reparo perineal - avaliada por EVA, considerando: muito insatisfeita, insatisfeita, satisfeita e muito satisfeita e oferecendo o espelho para que a mulher pudesse visualizar o local de reparo;

-Processo de cicatrização - hiperemia, edema, equimose, secreção e coaptação das bordas, segundo a escala REEDA, com escore de 0 a 15.

\subsubsection{Variáveis independentes}

-Reparo perineal com cola adesiva cirúrgica - aproximação das bordas da laceração de primeiro grau com Epiglu®;

-Reparo perineal com fio de sutura - aproximação das bordas da laceração de primeiro grau com fio Vicryl Rapide ${ }^{\circ}$, mediante técnica contínua com pontos não ancorados.

\subsubsection{Variáveis de caracterização}

-Idade materna - em anos completos;

- Cor da pele - autorreferida, classificada como branca, preta, parda, amarela ou indígena;

- Escolaridade - nenhuma, ensino fundamental incompleto, fundamental completo, médio completo ou superior incompleto e superior completo;

-Ocupação - trabalho remunerado ou não remunerado;

•Situação conjugal - vive ou não vive com parceiro;

-Índice de massa corpórea (IMC);

-Estado nutricional - classificado em baixo peso, adequado, sobrepeso e obesidade, de acordo com o IMC e a idade gestacional (Atalah et al., 1997);

-Paridade - partos vaginais anteriores sim ou não;

-Trauma perineal anterior suturado - sim ou não;

-Idade gestacional - em semanas completas, considerando data da última menstruação (DUM), ultrassonografia (USG) ou Capurro (em caso de incompatibilidade entre DUM e USG);

-Tempo decorrido entre a internação no CPN e o parto - em horas e frações;

-Tempo de bolsa rota - em horas e frações;

-Presença de acompanhante no parto - sim ou não; 
-Características da laceração - localização (clitóris, região vestibular, pequenos lábios, mucosa vaginal, corpo perineal);

-Uso de antibiótico intraparto ou pós-parto- sim ou não;

-Uso de anti-inflamatório pós-parto - sim ou não;

-Uso de analgésico pós-parto- sim ou não;

-Peso do recém-nascido $(\mathrm{RN})$ - em gramas;

-Perímetro cefálico do $\mathbf{R N}$ - em centímetros.

\subsection{TRATAMENTO E ANÁLISE DOS DADOS}

Os dados foram digitados em dupla entrada no software Excel. Para a análise descritiva das variáveis numéricas, foi feito o cálculo das medidas de tendência central e dispersão (média, mediana desvio-padrão e valores máximo e mínimo). Para as variáveis categóricas, foram calculadas as frequências absoluta e relativa.

$\mathrm{Na}$ análise inferencial, para as variáveis numéricas foram utilizados o teste WilcoxonMann-Whitney e o Linear Mixed Model (LMM) para medidas repetidas. Para as variáveis categóricas foram utilizados o teste exato de Fisher e o Generalized Estimating Equation (GEE).

Foram considerados estatisticamente significantes os valores de p menores que 0,05. As análises foram feitas utilizando o pacote estatístico Statistical Package for the Social Sciences (SPSS) para Windows (versão 12.0).

\subsection{ASPECTOS ÉTICOS}

O estudo foi aprovado pelo Comitê de Ética em Pesquisa da Escola de Enfermagem da Universidade de São Paulo (Axexo 1) e pelo Conselho Municipal de Itapecerica da Serra (Anexo 2).

A participação das mulheres foi voluntária e seguiu todas as determinações da Resolução n. 466, de 12 de dezembro de 2012, do Conselho Nacional de Saúde, assegurando que os direitos humanos dos envolvidos na pesquisa foram protegidos. O estudo foi 
registrado no Portal de Registro Brasileiro de Ensaios Clínicos http://www.ensaiosclinicos.gov.br/rg/RBR-2h84gt/ 
5 RESULTADOS 


\section{RESULTADO}

Os resultados apresentados a seguir referem-se à coleta de dados ocorrida entre 28 de agosto e 12 de novembro de 2017, no CPN do PMMZED. As participantes foram incluídas no estudo entre 28 de agosto e 31 de outubro e o seguimento no pós-parto até 12 de novembro. Durante esse período a pesquisadora esteve in loco para avaliação da elegibilidade das mulheres, convite para participação da pesquisa, randomização, reparo perineal e avaliação dos desfechos. Na etapa de avaliação dos desfechos outras três pesquisadoras treinadas contribuíram para coleta de informações, nas demais etapas uma pesquisadora foi responsável.

No período descrito, durante a permanência da pesquisadora no local, 51 mulheres foram avaliadas para elegibilidade e 38 foram consideradas elegíveis segundo os critérios de inclusão. Destas, 18 foram excluídas, 17 segundo os critérios pré-estabelecidos (períneo íntegro, laceração de primeiro grau sem necessidade de reparo, laceração de segundo grau, episiotomia e cesariana) e uma por recusa em participar.

Ao todo, 20 mulheres foram randomizadas. No GE, foram alocadas 10 mulheres, sem nenhuma perda de seguimento nas quatro etapas do estudo. No GC, foram alocadas 10 mulheres; neste houve uma perda de uma mulher na Etapa 4 do estudo devido ao não comparecimento à última avaliação, conforme apresentado no fluxograma a seguir (Figura 3). 
Figura 3 - Fluxograma das participantes, Itapecerica da Serra, SP - 2017

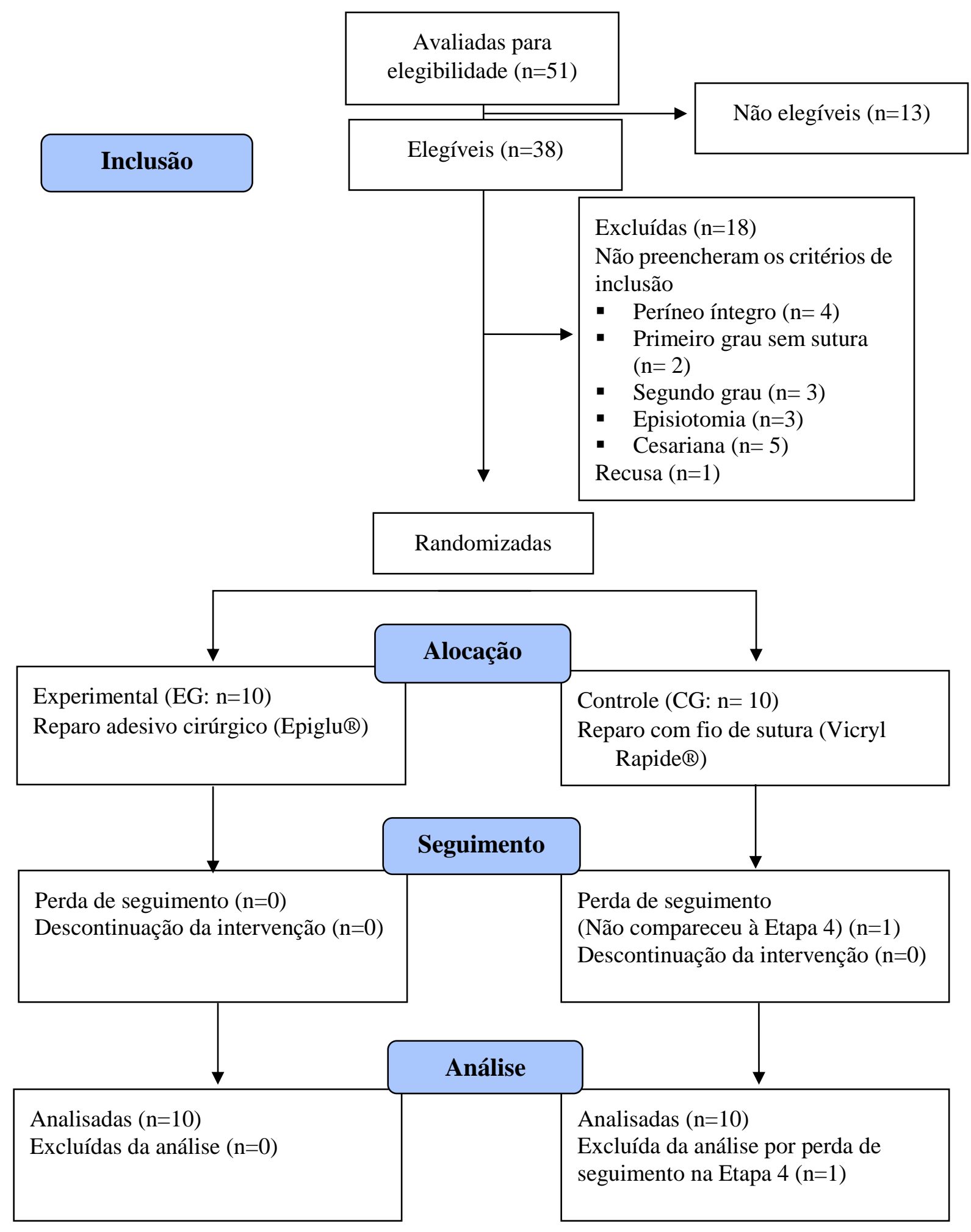

Fonte: A pesquisadora 
A seguir os resultados serão apresentados considerando os seguintes itens: 5.1 Caracterização da amostra (Tabelas 1 e 2; Figura 4); 5.2 Análise do tempo de reparo (Tabela 3); 5.3Análise da dor perineal (Tabela 4 e Figura 5); 5.4 Análise da cicatrização (Tabelas 5 a 8; Figuras 6 a 9) e 5.5 Análise da satisfação com o reparo perineal (Tabela 9 e Figuras 10 a 12).

\subsection{CARACTERIZAÇÃO DA AMOSTRA}

As Tabelas 1 e 2 apresentam a distribuição das características das mulheres e recémnascidos (RNs) dos GE e GC. Em todas as características apresentadas (cor da pele, escolaridade, ocupação, situação conjugal, estado nutricional, partos vaginais anteriores, trauma perineal anterior suturado e uso de antibiótico intraparto, idade, idade gestacional, IMC, tempo entre a internação e o parto, tempo de bolsa rota, peso e perímetro cefálico do RN) não houve diferença estatística entre os grupos experimental e controle.

Em relação à cor de pele, a mesma quantidade de mulheres se autodeclararam pardas (50\%), brancas (40\%) e pretas (10\%) em ambos os grupos. Nenhuma mulher se considerou amarela ou indígena. Quanto à escolaridade, prevaleceu a proporção de mulheres com escolaridade até ensino fundamental completo (55\%), sendo que no grupo experimental a proporção de mulheres com ensino médio foi maior (50\% vs 30\%). Apenas $15 \%$ das mulheres realizavam trabalho remunerado e nenhuma relatou ser estudante. Com relação à situação conjugal, $85 \%$ das mulheres vivem com o parceiro. O estado nutricional estava adequado em $50 \%$ das mulheres de ambos os grupos, porém $30 \%$ das participantes do GE tinham sobrepeso ou obesidade, em contraposição a 10\% do GC. A maioria das mulheres de ambos os grupos não tinha partos vaginais anteriores ( $\mathrm{GE}=60 \%$ e $\mathrm{GC}=70 \%), 20 \%$ tinham antecedente de sutura perineal $(\mathrm{GE}=10 \%$ e $\mathrm{CG}=30 \%)$. Apenas uma mulher em cada grupo recebeu antibiótico durante o trabalho de parto e parto (Tabela 1). Nenhuma mulher utilizou antibiótico pós-parto ou analgésicos. Todas as mulheres tiveram presença de acompanhante durante o trabalho de parto e parto (dados não apresentados em tabelas).

A média de idade das participantes foi 26,6 (d.p.=7,3) anos no GE e 21,7 (d.p.=5,7) anos no GC, a média da idade gestacional foi 38,9 (d.p.=1,3) e 38,8 (d.p.-0,6) semanas, no GE e GC, respectivamente, e a média do IMC foi 27,2 (d.p.=5,2) no GE e 25,5 (d.p.=4,8) no 
GC. O tempo médio entre a internação e o parto foi 6,2 horas em ambos os grupos (d.p.=4,4 horas no GE e d.p.=5,0 horas no GC) e de bolsa rota foi 6,4 (d.p.=6,4) horas no GE e de 3,9 (d.p.=5,2) horas no GC. No que se refere a características dos RNs, a média do peso foi 3.250,5 (d.p.=324,6) gramas e 3.020 (d.p.=330,8) gramas nos GE e GC, respectivamente, e do perímetro cefálico foi 34,6 (d.p.=1,0) centímetros no GE e 33,7 (d.p.=1,3) centímetros no GC (Tabela 2).

Tabela 1- Características das mulheres dos grupos experimental (GE) e controle (GC), segundo variáveis categóricas e valor-p, Itapecerica da Serra, SP - 2017

\begin{tabular}{|c|c|c|c|c|c|c|c|}
\hline \multirow{2}{*}{ Características } & \multicolumn{2}{|c|}{$\mathrm{GE}$} & \multicolumn{2}{|c|}{$\mathrm{GC}$} & \multicolumn{2}{|c|}{ Total } & \multirow{2}{*}{ Valor-p* } \\
\hline & $\mathrm{n}=10$ & $\%$ & $\mathrm{n}=10$ & $\%$ & $\mathrm{n}=20$ & $\%$ & \\
\hline \multicolumn{8}{|l|}{ Cor da pele } \\
\hline Parda & 5 & 50 & 5 & 50 & 10 & 50 & \multirow{3}{*}{1,000} \\
\hline Branca & 4 & 40 & 4 & 40 & 8 & 40 & \\
\hline Preta & 1 & 10 & 1 & 10 & 2 & 10 & \\
\hline \multicolumn{8}{|l|}{ Escolaridade } \\
\hline Ensino fundamental incompleto & - & - & 1 & 10 & 1 & 5 & \multirow{3}{*}{0,650} \\
\hline Ensino fundamental completo & 5 & 50 & 6 & 60 & 11 & 55 & \\
\hline Ensino médio complete & 5 & 50 & 3 & 30 & 8 & 40 & \\
\hline \multicolumn{8}{|l|}{ Ocupação } \\
\hline Não remunerada & 7 & 70 & 10 & 100 & 17 & 85 & \multirow{2}{*}{0,211} \\
\hline Remunerada & 3 & 30 & - & - & 3 & 15 & \\
\hline \multicolumn{8}{|l|}{ Situação conjugal } \\
\hline Vive com o parceiro & 8 & 80 & 9 & 90 & 17 & 85 & \multirow{2}{*}{1,000} \\
\hline Não vive com o parceiro & 2 & 20 & 1 & 10 & 3 & 15 & \\
\hline \multicolumn{8}{|l|}{ Estado nutricional } \\
\hline Baixo peso & 2 & 20 & 4 & 40 & 6 & 30 & \multirow{4}{*}{0,700} \\
\hline Adequado & 5 & 50 & 5 & 50 & 10 & 50 & \\
\hline Sobrepeso & 1 & 10 & - & - & 1 & 5 & \\
\hline Obesidade & 2 & 20 & 1 & 10 & 3 & 15 & \\
\hline \multicolumn{8}{|l|}{ Partos vaginais anteriores } \\
\hline Não & 6 & 60 & 7 & 70 & 13 & 65 & \multirow{2}{*}{1,000} \\
\hline Sim & 4 & 40 & 3 & 40 & 7 & 35 & \\
\hline \multicolumn{8}{|l|}{ Trauma vaginal anterior suturado } \\
\hline Não & 9 & 90 & 7 & 70 & 16 & 80 & \multirow{2}{*}{0,582} \\
\hline Sim & 1 & 10 & 3 & 30 & 4 & 20 & \\
\hline \multicolumn{8}{|l|}{ Antibiótico intraparto } \\
\hline Não & 9 & 90 & 9 & 90 & 18 & 90 & \multirow{2}{*}{1,000} \\
\hline Sim & 1 & 10 & 1 & 10 & 2 & 10 & \\
\hline
\end{tabular}

*Teste exato de Fisher 
Tabela 2- Caracterização das mulheres dos grupos experimental e controle, segundo variáveis numéricas e valor-p, Itapecerica da Serra, SP - 2017

\begin{tabular}{|c|c|c|c|c|c|c|c|c|}
\hline Características & Grupo & $\mathbf{n}$ & Média & d.p. & Mediana & Mín & Máx & Valor-p* \\
\hline \multicolumn{9}{|l|}{ Idade (anos) } \\
\hline & Experimental & 10 & 26,6 & 7,3 & 22,5 & 17 & 39 & \multirow{2}{*}{0,158} \\
\hline & Controle & 10 & 21,7 & 5,7 & 22 & 16 & 21 & \\
\hline \multicolumn{9}{|c|}{ Idade gestacional (sem) } \\
\hline & Experimental & 10 & 38,9 & 1,3 & 39,5 & 37 & 41 & \multirow{2}{*}{0,710} \\
\hline & Controle & 10 & 38,8 & 0,6 & 38 & 38 & 40 & \\
\hline \multicolumn{9}{|l|}{ IMC } \\
\hline & Experimental & 10 & 27,2 & 5,2 & 27,1 & 20 & 35 & \multirow{2}{*}{0,406} \\
\hline & Controle & 10 & 25,5 & 4,8 & 26,3 & 19 & 35 & \\
\hline \multicolumn{9}{|c|}{ Tempo entre internação e parto (h) } \\
\hline & Experimental & 10 & 6,2 & 4,4 & 4,9 & 0,4 & 15,0 & \multirow{2}{*}{0,880} \\
\hline & Controle & 10 & 6,2 & 5,0 & 4,9 & 0,7 & 17,6 & \\
\hline \multicolumn{9}{|c|}{ Tempo de bolsa rota $(\mathrm{h})$} \\
\hline & Experimental & 10 & 6,4 & 6,4 & 2,9 & 0,5 & 16,7 & \multirow{2}{*}{0,112} \\
\hline & Controle & 10 & 3,9 & 5,2 & 0,8 & 0,2 & 13,0 & \\
\hline \multicolumn{9}{|l|}{ Peso do RN (g) } \\
\hline & Experimental & 10 & 3250,5 & 324,6 & 3200,0 & 2810 & 3760 & \multirow{2}{*}{0,226} \\
\hline & Controle & 10 & 3020,0 & 330,8 & 3172,5 & 2545 & 3460 & \\
\hline \multicolumn{9}{|c|}{ Perímetro cefálico $(\mathrm{cm})$} \\
\hline & Experimental & 10 & 34,6 & 1,0 & 34,5 & 33 & 36 & \multirow{2}{*}{0,117} \\
\hline & Controle & 10 & 33,7 & 1,3 & 34,0 & 31 & 35 & \\
\hline
\end{tabular}

*Teste Wilcoxon-Mann-Whitney

Fonte: A pesquisadora

No que diz respeito a essas variáveis de caracterização, pode-se notar que não há diferença de distribuição entre os grupos de acordo com o valor-p obtido através do teste Exato de Fisher.

A Figura 4 ilustra a distribuição dos locais de laceração. As estruturas acometidas pelas lacerações foram clitóris $(n=2)$, pequenos lábios $(n=10)$, vestíbulo vulvar $(n=9)$, mucosa vaginal $(n=11)$ e corpo perineal $(n=5)$. 
Figura 4- Ilustração da região perineal e estruturas acometidas com lacerações de primeiro grau, Itapecerica da Serra, SP - 2017

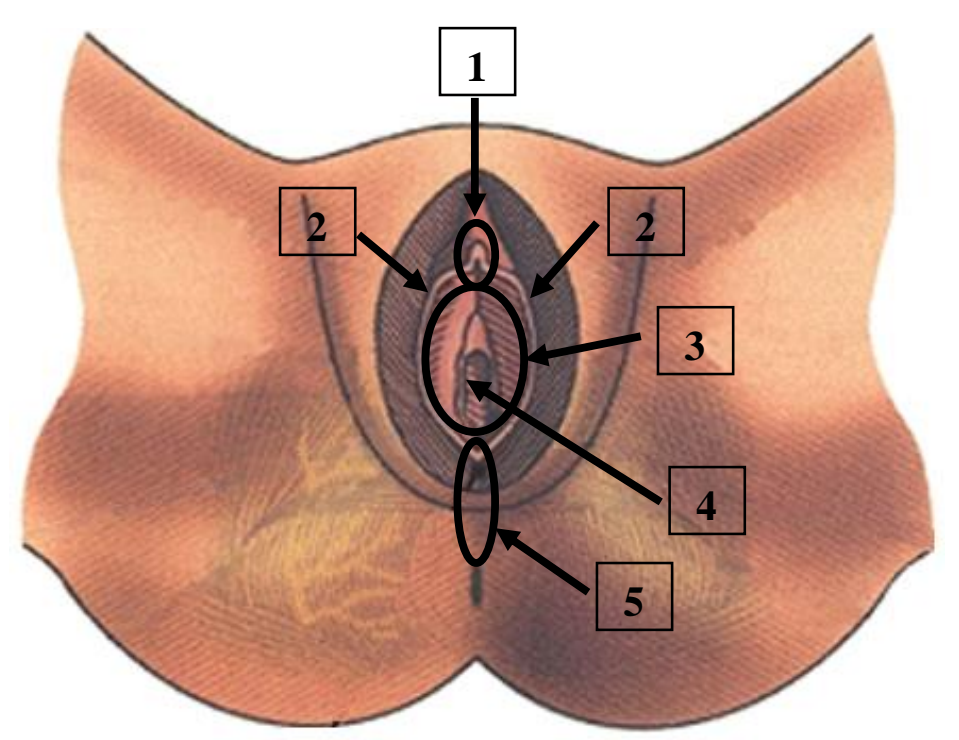

$\mathbf{1}$ clitóris, $\mathbf{2}$ pequenos lábios, $\mathbf{3}$ região vestibular, $\mathbf{4}$ mucosa vaginal, $\mathbf{5}$ fúrcula e corpo perineal

Fonte: Leite (2012) [adaptado]

\subsection{ANÁLISE DO TEMPO DE REPARO}

Em relação ao tempo utilizado para o reparo perineal, avaliado com uso do cronômetro digital, foi observada diferença estatisticamente significante entre os grupos $(\mathrm{p}<0,001)$, dado que a demora média foi de $5(\mathrm{~d} . \mathrm{p} .=3,6)$ minutos para o reparo no GE e de 21 (d.p.=5,9) minutos para o reparo no GC (Tabela 3).

Tabela 3 - Tempo de reparo perineal, em minutos, nos grupos experimental e controle, Itapecerica da Serra, SP - 2017

\begin{tabular}{lccccccc}
\hline \multirow{2}{*}{ Grupo } & \multirow{2}{*}{$\mathbf{N}$} & \multicolumn{5}{c}{ Tempo de reparo (min) } & \multirow{2}{*}{ Valor-p* } \\
\cline { 3 - 7 } & & Média & d.p. & Mediana & Mínimo & Máximo & \\
\hline Experimental & 10 & 5 & 3,6 & 5,5 & 1 & 10 & \multirow{2}{*}{$\mathbf{0 , 0 0 1}$} \\
Controle & 10 & 21 & 5,9 & 20,0 & 12 & 30 & \\
\hline
\end{tabular}

*Teste Wilcoxon-Mann-Whitney

Fonte: A pesquisadora 


\subsection{ANÁLISE DA DOR PERINEAL}

$\mathrm{Na}$ análise longitudinal da dor perineal, avaliada pela EVN, pode-se verificar que a interação entre grupo e tempo não é estatisticamente significante, ou seja, os grupos evoluíram de maneira semelhante no que se refere à dor ao longo do tempo. Em relação ao efeito tempo, de maneira isolada, observa-se que a dor muda, independentemente do grupo $(\mathrm{p}=0,013)$. Observa-se, ainda, que a média de dor das mulheres da amostra começa em 1,4 pontos, aumenta para 2,25 pontos, diminui para 1,65 pontos e termina em 0,4 pontos. Além disso, há uma diferença constante de escore maior no GE (p=0,036). (Tabela 4).

Tabela 4 - Distribuição das mulheres dos grupos experimental e controle segundo a dor perineal nas Etapas 1 a 4 do estudo e valor-p, Itapecerica da Serra, SP - 2017

\begin{tabular}{|c|c|c|c|c|c|c|c|}
\hline \multirow{3}{*}{ Tempo } & \multicolumn{4}{|c|}{ Dor } & \multicolumn{3}{|c|}{ Valor-p* } \\
\hline & \multicolumn{2}{|c|}{ Experimental } & \multicolumn{2}{|r|}{ Controle } & \multirow[b]{2}{*}{ Grupo } & \multirow[b]{2}{*}{ Tempo } & \multirow{2}{*}{$\begin{array}{c}\text { Grupo } x \\
\text { tempo }\end{array}$} \\
\hline & $\mathbf{n}$ & $\begin{array}{l}\text { Média } \\
\text { (d.p) }\end{array}$ & $\mathbf{n}$ & Média (d.p) & & & \\
\hline Até $2 \mathrm{~h}$ & 10 & $0,4(1,3)$ & 10 & $2,4(1,9)$ & \multirow{5}{*}{$\mathbf{0 , 0 3 6}$} & \multirow{5}{*}{$\mathbf{0 , 0 1 3}$} & \multirow{5}{*}{0,226} \\
\hline $12-24 h$ & 10 & $2,0(2,3)$ & 10 & $2,5(2,7)$ & & & \\
\hline $36-48 h$ & 10 & $0,8(0,9)$ & 10 & $2,5(2,8)$ & & & \\
\hline 10-20 dias & 10 & $0,2(0,6)$ & 9 & $0,6(1,1)$ & & & \\
\hline Total & 40 & $0,9(1,3)$ & 39 & $2,0(2,1)$ & & & \\
\hline
\end{tabular}

Fonte: A pesquisadora

A Figura 5, a seguir, ilustra a evolução da dor perineal no GE e no GC nas quatro etapas do estudo. 
Figura 5- Evolução da dor perineal segundo o escore a EVN nos grupos experimental (GE) e controle (GC) nas Etapas 1 a 4 do estudo, Itapecerica da Serra, SP - 2017

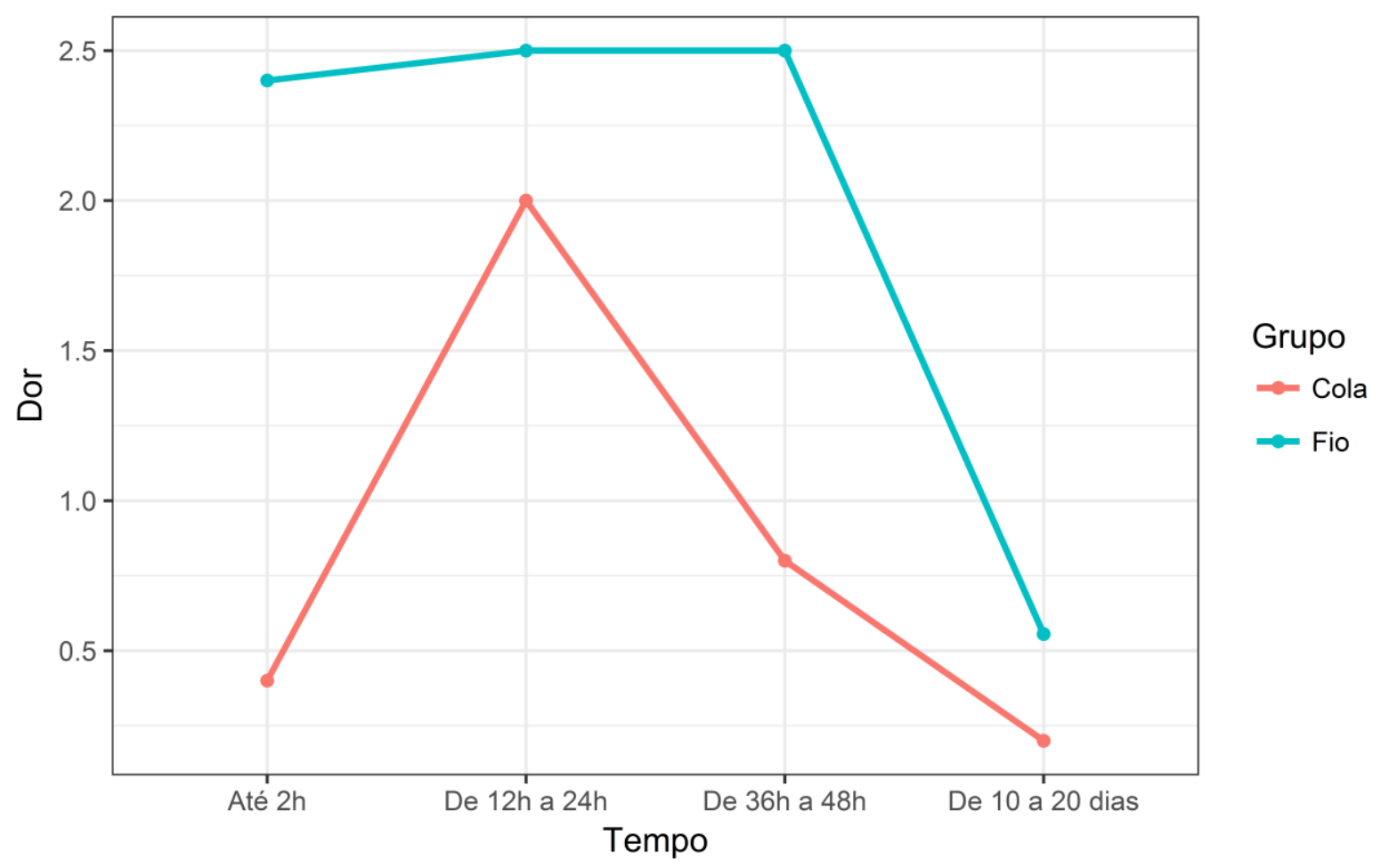

Fonte: A pesquisadora

\subsection{ANÁLISE DA CICATRIZAÇÃo}

O mesmo modelo de análise estatística referido para a dor perineal foi utilizado para analisar a cicatrização. A avaliação deste desfecho pela escala REEDA foi analisada considerando o total do escore para cada grupo (Tabela 5 e Figura 6) e, também, separadamente para cada um dos itens da escala que mostram variação (edema, equimose e coaptação das bordas da laceração) (Tabelas 6 a 8 e Figuras 7 a 9).

Sobre a cicatrização perineal, observa-se que os grupos evoluíram de maneira semelhante ao longo do tempo, sem interação entre grupo e tempo $(\mathrm{p}=0,456)$. A cicatrização se modificou ao longo do tempo, independentemente do grupo $(0,049)$ e há uma diferença de cicatrização constante entre os grupos $(\mathrm{p}=0,018)$, com escores menores no GE e diferença de média no total das três avaliações de 0,6 pontos. Na avaliação de 12 a 24 horas, a diferença 
foi de 1,3 pontos, entre 36-48 horas foi de 0,6 pontos e de 10-20 dias foi de 0,7 pontos, com piores escores no GC (Tabela 5).

Tabela 5- Distribuição das mulheres dos grupos experimental e controle segundo o escore da escala REEDA nas Etapas 2 a 4 do estudo e valor-p, Itapecerica da Serra, SP - 2017

\begin{tabular}{|c|c|c|c|c|c|c|c|}
\hline \multirow{3}{*}{ Tempo } & \multicolumn{4}{|c|}{ REEDA } & \multicolumn{3}{|c|}{ Valor-p* } \\
\hline & \multicolumn{2}{|c|}{ Experimental } & \multicolumn{2}{|r|}{ Controle } & \multirow[b]{2}{*}{ Grupo } & \multirow[b]{2}{*}{ Tempo } & \multirow{2}{*}{$\begin{array}{c}\text { Grupo } x \\
\text { tempo }\end{array}$} \\
\hline & $\mathbf{n}$ & $\begin{array}{l}\text { Média } \\
\text { (d.p) }\end{array}$ & $\mathbf{N}$ & Média (d.p) & & & \\
\hline $12-24 \mathrm{~h}$ & 10 & $0,5(1,0)$ & 10 & $1,8(1,4)$ & \multirow{4}{*}{0,018} & \multirow{4}{*}{0,049} & \multirow{4}{*}{0,456} \\
\hline $36-48 \mathrm{~h}$ & 10 & $0,6(0,8)$ & 10 & $1,2(1,5)$ & & & \\
\hline $10-20$ dias & 10 & 0,0 & 9 & $0,7(1,0)$ & & & \\
\hline Total & 30 & $0,4(0,6)$ & 29 & $1.2(1.1)$ & & & \\
\hline
\end{tabular}

*LMM

Fonte: A pesquisadora

A Figura 6, a seguir, ilustra a evolução do processo cicatricial da laceração perineal no GE e no GC nas quatro etapas do estudo.

Figura 6 - Evolução do processo cicatricial segundo escore da escala REEDA nos grupos experimental (GE) e controle (GC) nas Etapas 2 a 4 do estudo, Itapecerica da Serra, SP 2017

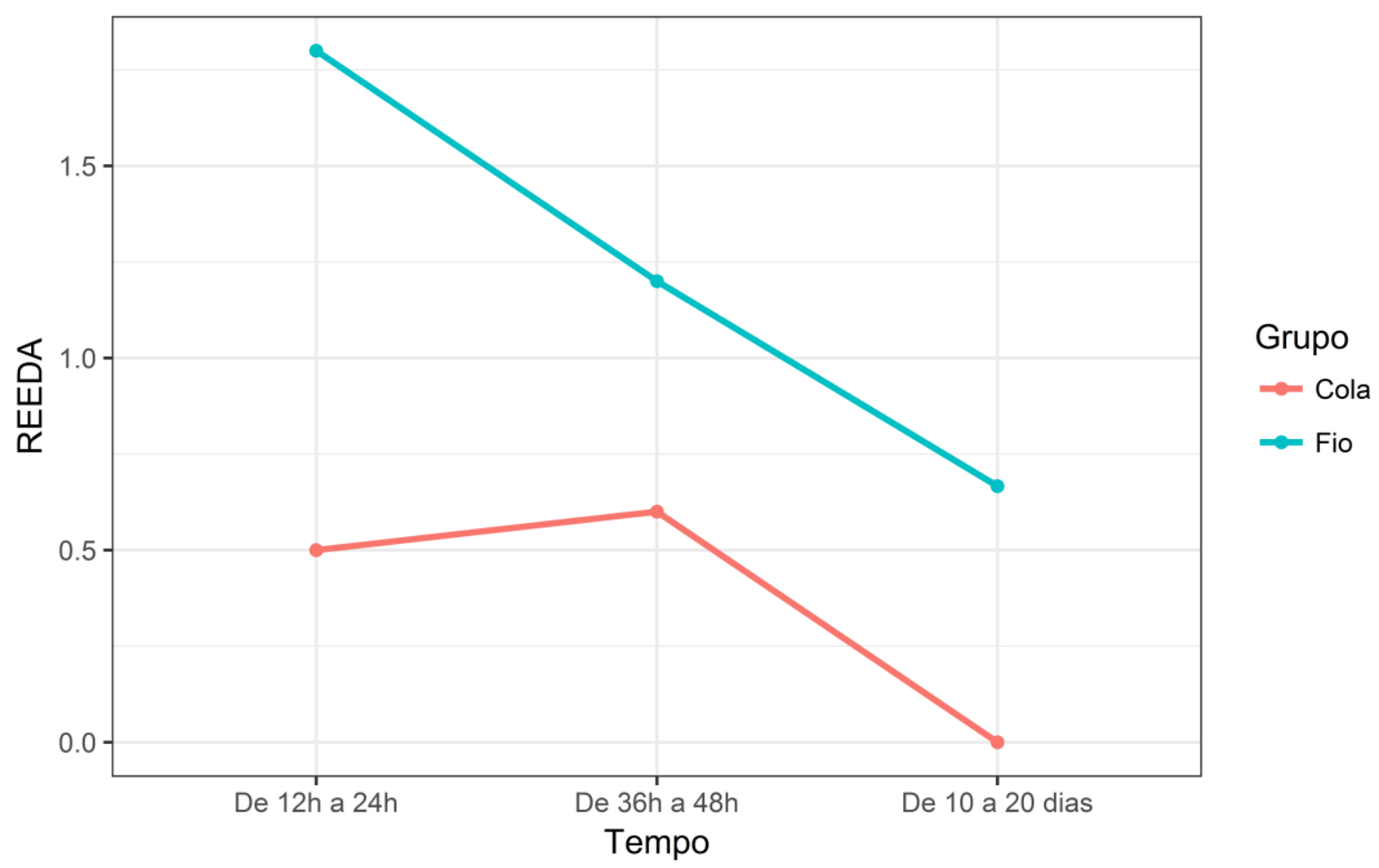

Fonte: A pesquisadora 
Na análise em separado dos parâmetros que compõem a escala REEDA (hiperemia, equimose, edema, secreção e coaptação), verificou-se que nenhuma das participantes apresentou hiperemia ou secreção decorrentes da laceração perineal.

Em relação ao edema, observa-se que a interação entre grupo e tempo não é significante, portanto, o edema se comportou de maneira semelhante em ambos os grupos ao longo do tempo. Observa-se que o escore do edema diminuiu ao longo do tempo, independentemente do grupo $(0,028)$, com diferença significante na redução do edema em ambos os grupos $(\mathrm{p}=0,018)$, com escores menores no GE e diferença de média no total das três avaliações de 0,6 pontos (Tabela 6).

Tabela 6- Distribuição das mulheres dos grupos experimental e controle segundo o escore do edema perineal nas Etapas 2 a 4 do estudo e valor-p, Itapecerica da Serra, SP - 2017

\begin{tabular}{|c|c|c|c|c|c|c|c|}
\hline \multirow{3}{*}{ Tempo } & \multicolumn{4}{|c|}{ Edema } & \multicolumn{3}{|c|}{ Valor-p* } \\
\hline & \multicolumn{2}{|c|}{ Experimental } & \multicolumn{2}{|r|}{ Controle } & \multirow[b]{2}{*}{ Grupo } & \multirow[b]{2}{*}{ Tempo } & \multirow{2}{*}{$\begin{array}{c}\text { Grupo } x \\
\text { tempo }\end{array}$} \\
\hline & $\mathbf{n}$ & $\begin{array}{c}\text { Média } \\
\text { (d.p) }\end{array}$ & $\mathbf{n}$ & Média (d.p) & & & \\
\hline $12-24 h$ & 10 & $0,3(0,7)$ & 10 & $1,1(1,0)$ & \multirow{4}{*}{0,018} & \multirow{4}{*}{$\mathbf{0 , 0 2 8}$} & \multirow{4}{*}{0,433} \\
\hline $36-48 h$ & 10 & $0,1(0,3)$ & 10 & $0,5(0,8)$ & & & \\
\hline 10-20 dias & 10 & 0,0 & 9 & $0,3(0,5)$ & & & \\
\hline Total & 30 & $0,1(0,3)$ & 29 & $0,6(0,8)$ & & & \\
\hline
\end{tabular}

A Figura 7, a seguir, ilustra a evolução do edema perineal no GE e no GC nas quatro etapas do estudo. 
Figura 7- Evolução do edema perineal nos grupos experimental (GE) e controle (GC) nas Etapas 2 a 4 do estudo, Itapecerica da Serra, SP - 2017

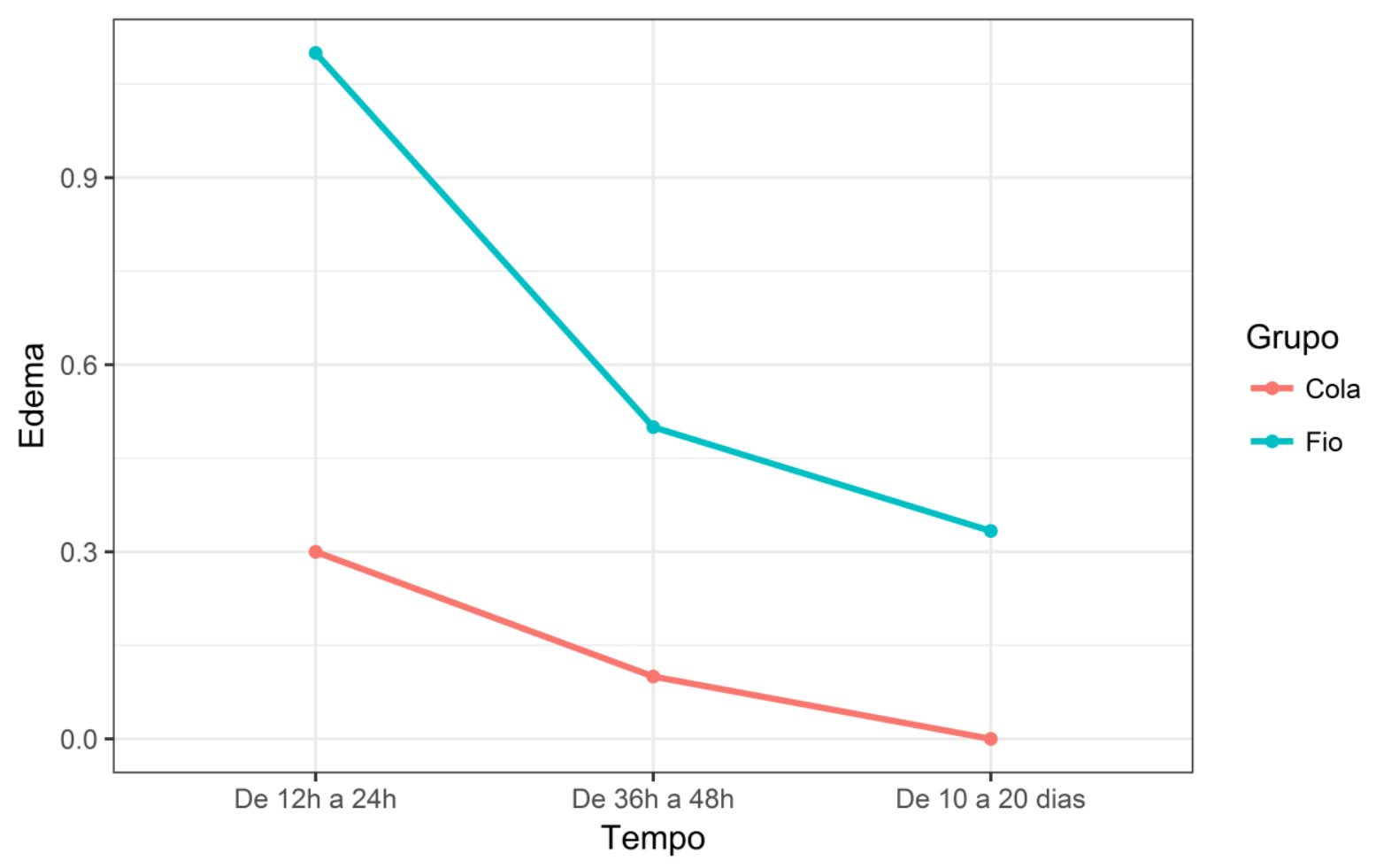

Fonte: A pesquisadora

A equimose ocorreu exclusivamente no grupo submetido ao reparo com fio cirúrgico (GC). Apesar do valor-p >0,05 em todas as análises, a diferença entre os grupos é clara, uma vez que o GE não presentou nenhum caso de equimose (Tabela 7).

Tabela 7 - Distribuição das mulheres dos grupos experimental e controle segundo o escore da equimose perineal nas Etapas 2 a 4 do estudo e valor-p, Itapecerica da Serra, SP - 2017

\begin{tabular}{|c|c|c|c|c|c|c|c|}
\hline \multirow{3}{*}{ Tempo } & \multicolumn{4}{|c|}{ Equimose } & \multicolumn{3}{|c|}{ Valor-p* } \\
\hline & \multicolumn{2}{|c|}{ Experimental } & \multicolumn{2}{|r|}{ Controle } & \multirow[b]{2}{*}{ Grupo } & \multirow[b]{2}{*}{ Tempo } & \multirow{2}{*}{$\begin{array}{c}\text { Grupo } x \\
\text { tempo }\end{array}$} \\
\hline & $\mathbf{n}$ & $\begin{array}{l}\text { Média } \\
\text { (d.p) }\end{array}$ & $\mathbf{N}$ & Média (d.p) & & & \\
\hline $12-24 \mathrm{~h}$ & 10 & - & 10 & $0,7(1,2)$ & \multirow{4}{*}{0,137} & \multirow{4}{*}{0,076} & \multirow{4}{*}{0,076} \\
\hline $36-48 \mathrm{~h}$ & 10 & - & 10 & $0,5(1,1)$ & & & \\
\hline $10-20$ dias & 10 & - & 9 & - & & & \\
\hline Total & 30 & - & 29 & $0,4(0,8)$ & & & \\
\hline
\end{tabular}

*LMM

Fonte: A pesquisadora 
A Figura 8, a seguir, ilustra a evolução da equimose perineal no GE e no GC nas quatro etapas do estudo.

Figura 8- Evolução da equimose perineal nos grupos experimental (GE) e controle (GC) nas Etapas 2 a 4 do estudo, Itapecerica da Serra, SP - 2017

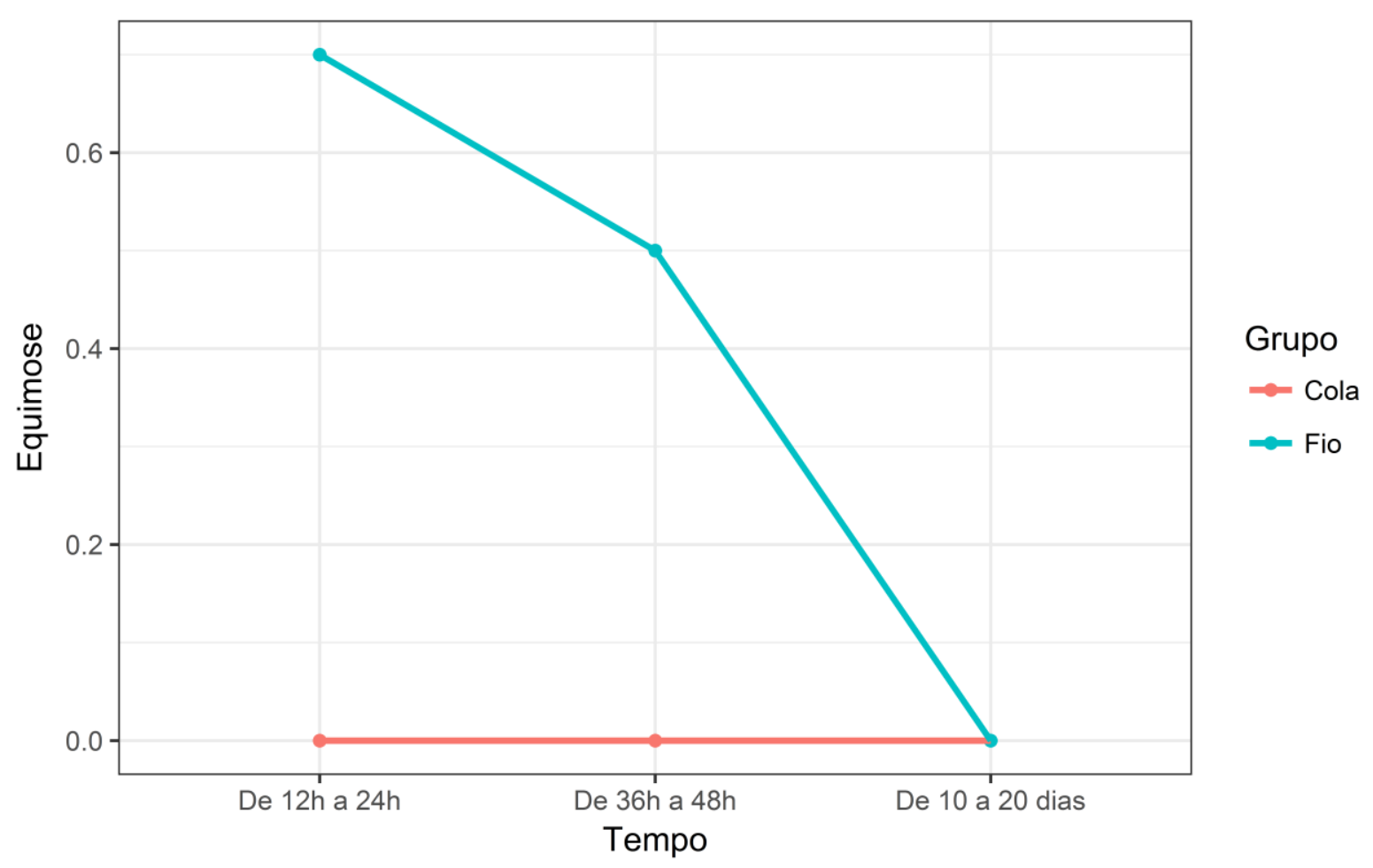

Fonte: A pesquisadora

$\mathrm{Na}$ análise do escore de coaptação das bordas, verifica-se que houve interação entre grupo e tempo e, portanto, os grupos tiveram evolução diferente ao longo do tempo ( $\mathrm{p}=0,034)$. Inicialmente, até 24 horas após o parto, a coaptação foi melhor no GC; no entanto, na última avaliação (entre 10 e 20 dias após o parto), entre as mulheres do GE a coaptação estava perfeita (Tabela 8). 
Tabela 8- Distribuição das mulheres dos grupos experimental e controle segundo o escore da coaptação das bordas da laceração perineal nas Etapas 2 a 4 do estudo e valor-p, Itapecerica da Serra, SP, 2017

\begin{tabular}{|c|c|c|c|c|c|c|c|}
\hline \multirow{3}{*}{ Tempo } & \multicolumn{4}{|c|}{ Coaptação } & \multicolumn{3}{|c|}{ Valor-p* } \\
\hline & \multicolumn{2}{|c|}{ Experimental } & \multicolumn{2}{|r|}{ Controle } & \multirow[b]{2}{*}{ Grupo } & \multirow[b]{2}{*}{ Tempo } & \multirow{2}{*}{$\begin{array}{c}\text { Grupo } x \\
\text { tempo }\end{array}$} \\
\hline & $\mathbf{N}$ & $\begin{array}{l}\text { Média } \\
\text { (d.p) }\end{array}$ & $\mathbf{n}$ & Média (d.p) & & & \\
\hline $12-24 \mathrm{~h}$ & 10 & $0,3(0,5)$ & 10 & - & \multirow{4}{*}{0,666} & \multirow{4}{*}{0,831} & \multirow{4}{*}{$\mathbf{0 , 0 3 4}$} \\
\hline $36-48 \mathrm{~h}$ & 10 & $0,3(0,5)$ & 10 & $0,1(0,3)$ & & & \\
\hline $10-20$ dias & 10 & - & 9 & $0,3(0,7)$ & & & \\
\hline Total & 30 & $0,2(0,3)$ & 29 & $0,1(0,3)$ & & & \\
\hline
\end{tabular}

*LMM

Fonte: A pesquisadora

A Figura 9, a seguir, ilustra a mudança nos grupos ao longo do tempo. A melhor coaptação inicial no GC se mantém durante a internação. Entretanto, após a alta, a coaptação no GE se mostrou melhor.

Figura 9 - Evolução da coaptação das bordas da laceração perineal nos grupos experimental (GE) e controle (GC) nas Etapas 2 a 4 do estudo, Itapecerica da Serra, SP - 2017

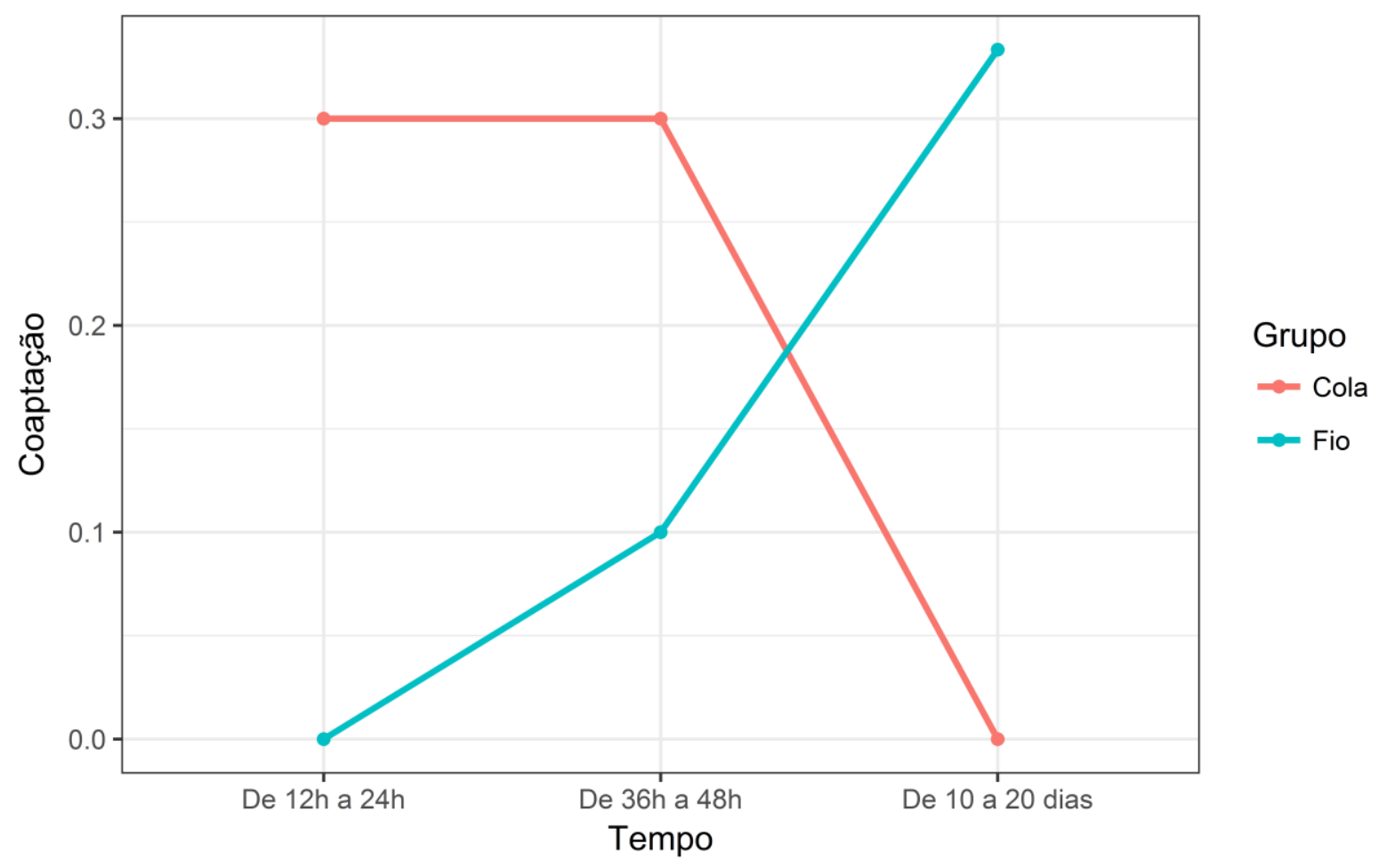

Fonte: A pesquisadora 


\subsection{ANÁLISE DA SATISFAÇÃO COM O REPARO PERINEAL}

Em relação à satisfação das mulheres com o reparo perineal, avaliada por meio da EVA, observa-se que a totalidade das mulheres do GE manifestou-se satisfeita ou muito satisfeita em todas as etapas do estudo, ao passo que entre aquelas do GC, variou de $10 \%$ a $20 \%$ a proporção de mulheres que se declaram muito insatisfeitas ou insatisfeitas com o reparo, com diferença estatisticamente significante entre os grupos $(\mathrm{p}<0,001)$ e ao longo do tempo $(\mathrm{p}=0,009)$ (Tabela 9).

Vale reiterar que, para a avaliação da satisfação, foi oferecido à mulher um espelho para que ela visualizasse o local do reparo.

Tabela 9 - Satisfação das mulheres dos grupos experimental (GE) e controle (GC) em relação ao reparo perineal nas Etapas 1 a 4 do estudo, Itapecerica da Serra, SP - 2017

\begin{tabular}{|c|c|c|c|c|c|c|c|c|c|c|c|c|c|}
\hline \multirow{4}{*}{ Etapa } & \multicolumn{9}{|c|}{ Satisfação } & \multicolumn{4}{|c|}{ Valor-p* } \\
\hline & \multicolumn{5}{|c|}{ GE } & \multicolumn{5}{|c|}{ GC } & \multirow{3}{*}{ Grupo } & \multirow{3}{*}{ Etapa } & \multirow{3}{*}{$\begin{array}{c}\text { Grupo } \\
\quad \mathbf{x} \\
\text { Etapa }\end{array}$} \\
\hline & \multirow[b]{2}{*}{$\mathbf{n}$} & MI & I & $\mathbf{S}$ & MS & \multirow[b]{2}{*}{$\mathbf{n}$} & \multirow{2}{*}{\multicolumn{2}{|c|}{$\begin{array}{c}\mathbf{I} \\
\mathbf{N} \\
(\%)\end{array}$}} & \multirow{2}{*}{$\begin{array}{c}\mathbf{S} \\
\mathbf{n} \\
(\%)\end{array}$} & \multirow{2}{*}{$\begin{array}{c}\text { MS } \\
\mathbf{n} \\
(\%)\end{array}$} & & & \\
\hline & & $\begin{array}{c}\mathbf{n} \\
(\%)\end{array}$ & $\begin{array}{c}\mathbf{n} \\
(\%)\end{array}$ & $\begin{array}{c}n \\
(\%)\end{array}$ & $\begin{array}{c}\mathbf{n} \\
(\%)\end{array}$ & & & & & & & & \\
\hline 1 & 10 & - & - & 4 & 6 & 10 & - & 1 & 6 & 3 & & & \\
\hline & & - & - & (40) & (60) & 10 & - & (10) & (60) & (30) & & & \\
\hline 2 & 10 & - & - & 7 & 3 & 10 & 1 & 2 & 6 & 1 & & & \\
\hline 2 & 10 & - & - & (70) & (30) & 10 & (10) & (20) & (60) & (10) & & & \\
\hline 3 & 10 & - & - & $\begin{array}{c}3 \\
(30)\end{array}$ & $\begin{array}{c}7 \\
(70)\end{array}$ & 10 & - & $\begin{array}{c}1 \\
(10)\end{array}$ & $\begin{array}{c}7 \\
(70)\end{array}$ & $\begin{array}{c}2 \\
(20)\end{array}$ & $<0,001$ & 0,009 & 0,153 \\
\hline & & - & - & (30) & $\begin{array}{l}(70) \\
10\end{array}$ & & $\overline{1}$ & $\begin{array}{c}\text { (10) } \\
1\end{array}$ & 5 & 2 & & & \\
\hline 4 & 10 & - & - & - & (100) & 9 & $(11,1)$ & $(11,1)$ & $(55,6)$ & $(22,2)$ & & & \\
\hline Total & 40 & - & - & 14 & 26 & 39 & 2 & 5 & 24 & 8 & & & \\
\hline & (100) & - & - & (35) & (65) & (100) & (5) & (12) & (61) & (20) & & & \\
\hline
\end{tabular}

MI: muito insatisfeita; I: insatisfeita; S: satisfeita; MS: muito satisfeita *GEE

A Figura 10, a seguir, apresenta a diferença de avaliação entre os GC e GE ao longo das etapas. 
Figura 10 - Satisfação da mulher com reparo perineal nos grupos experimental (GE) e controle (GC) nas Etapas 1 a 4 do estudo, Itapecerica da Serra, SP - 2017

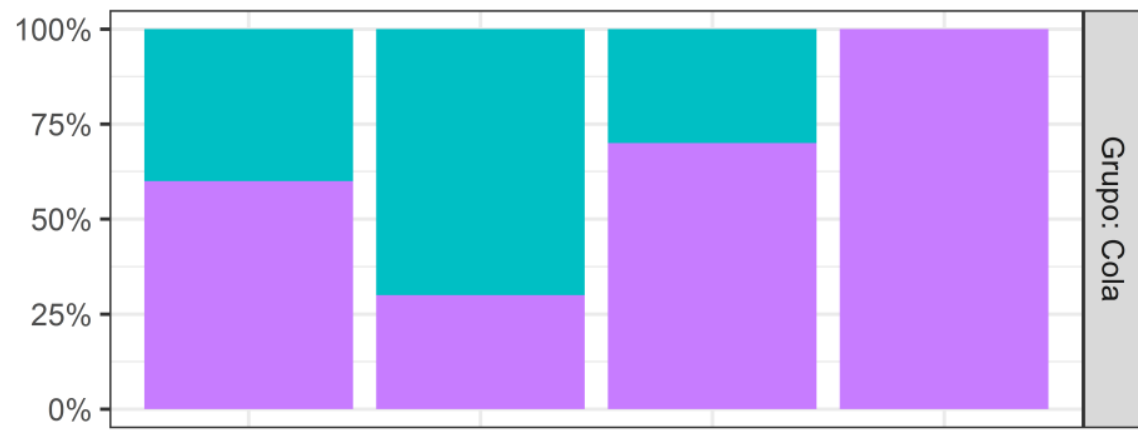

\section{Satisfação}

Insatisfeita

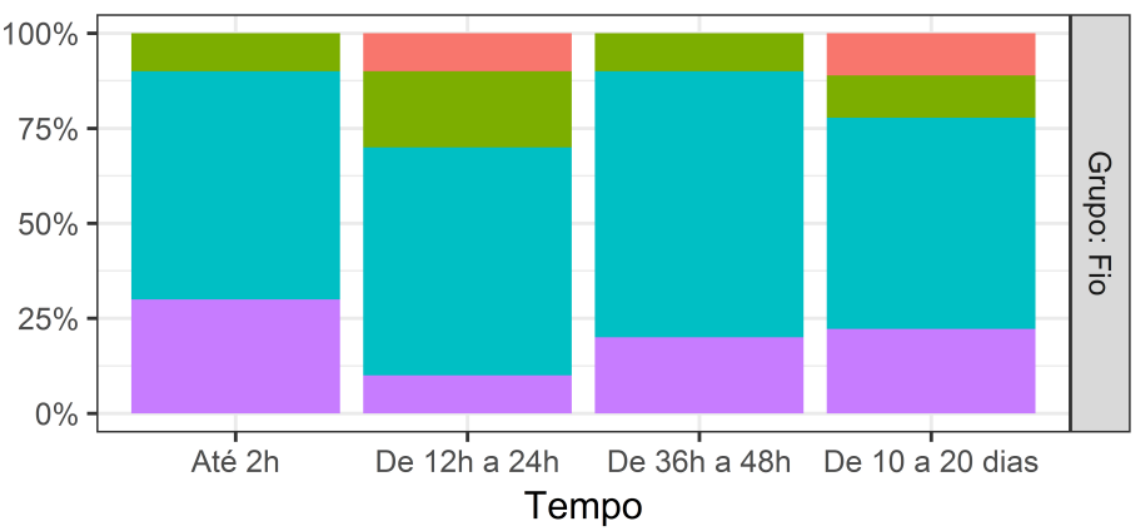

Pouco satisfeita

\section{Satisfeita}

Muito satisfeita

Fonte: A pesquisadora

As figuras 11 e 12, a seguir, mostram a aparência do períneo reparado, imediatamente após o reparo e na Etapa 4, em uma mulher do GE e uma do GC, respectivamente. 
Figura 11 - Reparo no pequeno lábio esquerdo realizado com fio de sutura Vicryl Rapide® nas Etapas 1 a 4 do estudo, Itapecerica da Serra, SP - 2017

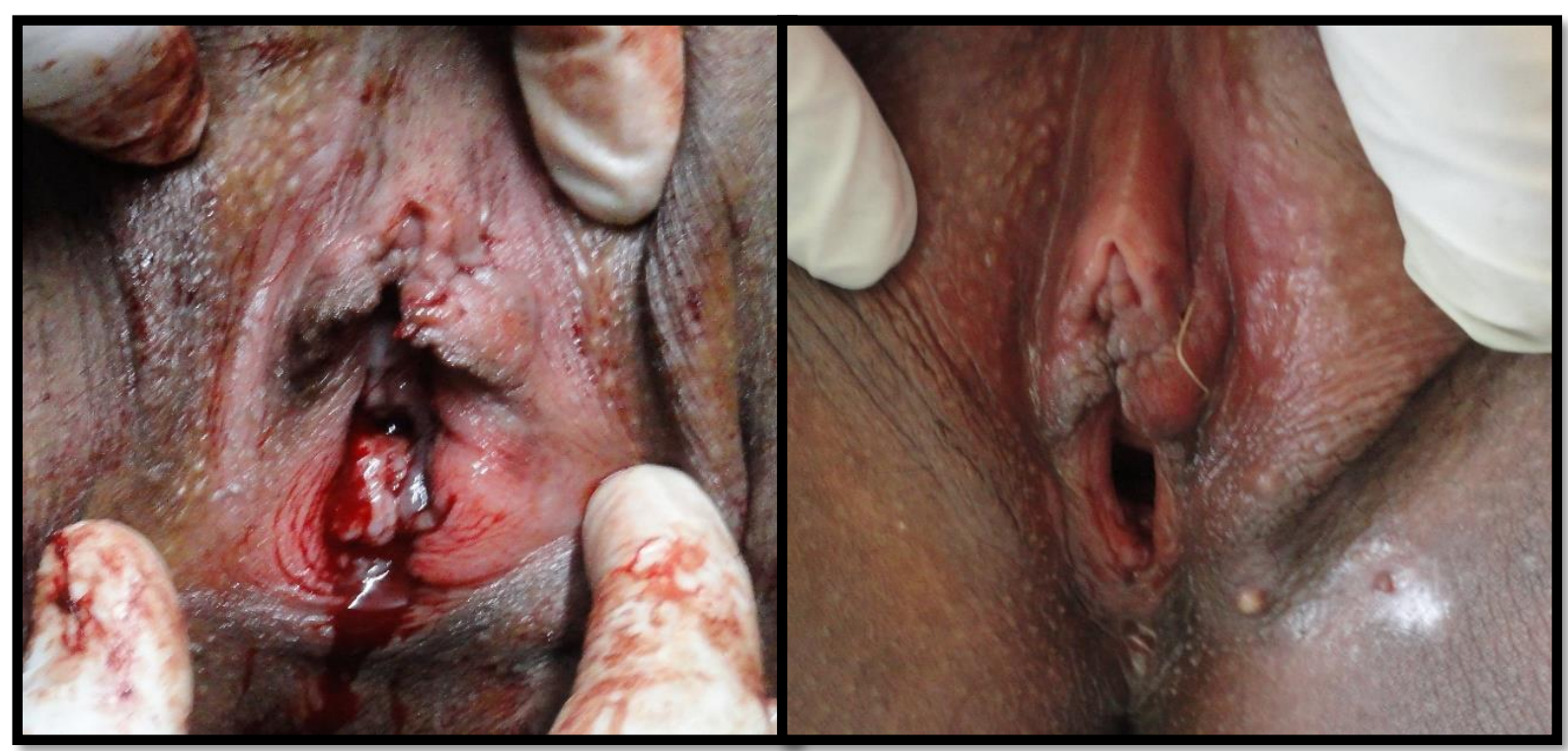

Fonte: A pesquisadora

Figura 12 - Reparo na fúrcula e corpo perineal realizado com cola adesiva cirúrgica Epiglu® nas Etapas 1 a 4 do estudo, Itapecerica da Serra, SP - 2017

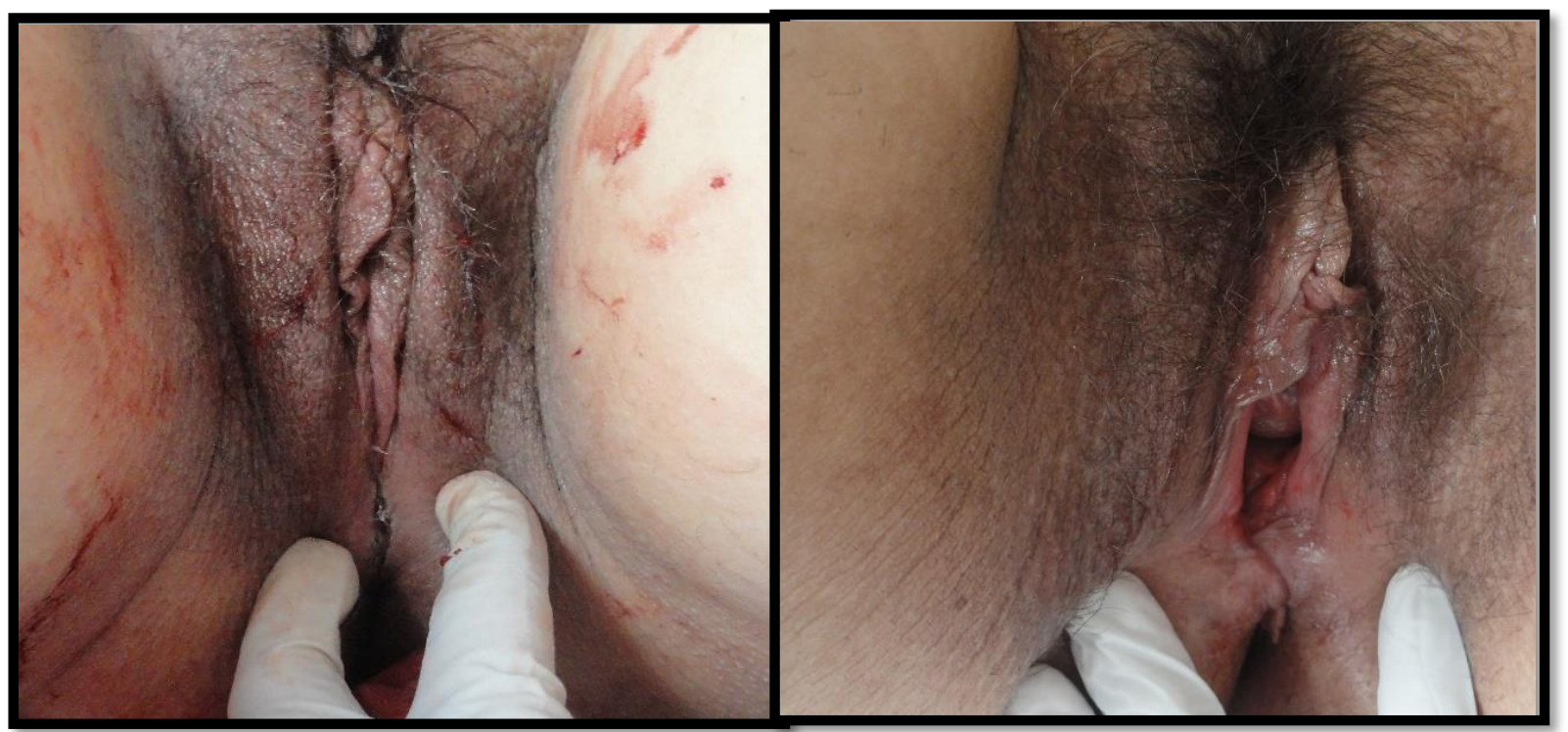

Fonte: A pesquisadora 


\section{DISCUSSÃO}

A discussão dos resultados deste estudo piloto é apresentada considerando sua adequabilidade metodológica e implicações em relação ao reparo perineal com ambas as técnicas, conforme os seguintes itens: 6.1 Desenvolvimento do estudo; 6.2 Avaliação da dor perineal; 6.3 Avaliação do processo de cicatrização; 6.4 Avaliação do tempo de reparo; 6.5 Avaliação da satisfação das mulheres; 6.6 Limitações e fortalezas; 6.7 Implicações para pesquisa; 6.8 Implicações para prática.

\subsection{DESENVOLVIMENTO DO ESTUDO}

Os estudos sobre o uso de colas adesivas cirúrgicas no reparo perineal durante o parto normal são escassos na literatura; dentre os existentes todos utilizaram colas adesivas à base de cianoacrilato. Após a análise desses estudos, conforme apresentado no Quadro 1 da Introdução, foi observado que para o cálculo amostral de cada um deles foram utilizadas diferentes metodologias, o que implica diferentes tamanhos amostrais. Desta forma, foi considerada a necessidade da realização deste estudo piloto, de modo a observar as diferenças das médias de dor e desvio padrão entre os dois grupos e estimar o número de participantes necessários para que haja diferença estatisticamente significante com erro do tipo I de $5 \%$ e poder de teste de $95 \%$.

Após análise dos dados obtidos, foi calculado o número amostral através da observação da evolução da dor ao longo do tempo e, de acordo com os achados, é necessário um número total de 70 participantes, sendo 35 no grupo experimental e 35 no grupo controle, para que se detecte uma diferença significativa no escore de dor ao longo das avaliações. Os estudos anteriores que apresentam o tamanho amostral aproximado ao cálculo obtido foram Chamariya, Prasad e Chauhan (2016) e Mota et al. (2009), apesar da metodologia divergir entre eles e entre o atual estudo.

Feigenberg et al. (2014) realizou o reparo em lacerações de primeiro grau e seu tamanho amostral difere do tamanho calculado por este estudo. Naquele estudo, foram 
alocados 74 no grupo experimental e 28 participantes no grupo controle. Inicialmente, os pesquisadores avaliariam dois

tipos de cola e, após um estudo piloto, optaram por realizar a intervenção com apenas um dos tipos, mantendo o mesmo número de participantes no grupo experimental.

Além da necessidade do cálculo amostral confiável, a principal função de um estudo piloto no planejamento de uma pesquisa é testar questões práticas e adequar a metodologia proposta, ajustando procedimentos previamente planejados. Além disso, pode também funcionar como controle de qualidade para procedimentos clínicos. Desta forma, minimizase a chance de erros na condução de um estudo maior e, por consequência, a construção de falsas conclusões (Armstrong, 2008).

A principal vantagem do presente estudo foi aprimorar a técnica de aplicação da cola adesiva cirúrgica nas lacerações perineais de primeiro grau. Inicialmente, havia sido proposto pelo fabricante aplicar uma camada fina da cola com o dispensador, aguardar alguns segundos e aplicar uma segunda camada fina; no caso de necessidade, aplicar uma terceira camada. Durante a realização do procedimento, foi observado que quanto mais camadas ou mais espessa se apresenta a camada, com mais frequência a cola se desprendeu durante o procedimento.

Essa diferença provavelmente deve-se ao fato de a cola ser comumente utilizada em locais que ficam constantemente secos, como a pele ou sobre o fechamento cirúrgico com fio, com a finalidade de vedar a sutura cirúrgica. O períneo é uma região que fica constantemente úmida, principalmente após o parto, além de possuir tipos de tecidos distintos (pele, mucosa e uniões muco-cutâneas); portanto, a aderência da cola nesse local apresentou especificidades não informadas pelo fabricante.

No caso das lacerações perineais, como explicitado na metodologia deste trabalho, o local do reparo foi seco com auxílio de uma gaze estéril e as bordas foram aproximadas com o auxílio dos dedos indicador e polegar. No momento em que a ferida está aproximada, devese aplicar a menor quantidade possível de cola adesiva cirúrgica e aguardar a polimerização por completo. Por tratar-se de um etil-2-cianoacrilato, a polimerização ocorreu em aproximadamente 30 segundos. Muitas vezes, o reparo ficou imperceptível, salvo pela camada ligeiramente turva e endurecida no local de aplicação da mesma. 
Referente à localização da laceração, é interessante destacar que para as lacerações ocorridas nos pequenos lábios ou região vestibular, por tratar-se de uma região rugosa e com maior maleabilidade, a junção das bordas das feridas com o polegar e dedo indicador se torna difícil. Portanto, a melhor forma de aproximar as bordas das feridas nessa região é realizando uma leve tração no ápice dos pequenos lábios com uma das mãos. Desta forma, as bordas se mantêm apostas e o reparo pode ser realizado sem maiores dificuldades.

Em relação às variáveis de caracterização, critérios de inclusão e exclusão, todos se apresentaram adequados para continuidade do estudo. Após a análise do escore de dor, foi verificado que seria importante incluir duas variáveis de caracterização de laceração: a extensão e a profundidade. Sabe-se que as lacerações de primeiro grau são aquelas que acometem apenas pele e mucosa, sem atingir o músculo. Entretanto, diferentes extensões e profundidades podem alterar a percepção de dor das mulheres.

É importante destacar que a efetividade da cola adesiva cirúrgica foi comparada com uma técnica de reparo considerada padrão ouro (sutura contínua com poliglactina 910 de rápida absorção), incluindo exclusivamente mulheres que tinham indicação de reparo das lacerações de primeiro grau (laceração com sangramento que não cessa ou com bordas afastadas), com base nas melhores práticas e nas diretrizes do Ministério da Saúde brasileiro (Brasil, 2016; Nice, 2014).

Por tratar-se de um estudo piloto, as diferenças obtidas nos achados podem ter ocorrido ao acaso, considerando que o tamanho amostral não foi calculado para detectar uma diferença significativa entre os grupos. Entretanto, os desfechos analisados - dor perineal, cicatrização, satisfação com o reparo perineal e tempo despendido para o reparo - apontam resultados favoráveis ao uso da cola adesiva cirúrgica. Além disso, as similaridades das variáveis de caracterização da amostra apontam a eficácia da randomização.

\subsection{AVALIAÇÃO DA DOR PERINEAL}

O estudo mais antigo com uso de n-butyl-2-cyanoacrylate (Histoacryl@) para o reparo da pele da episiotomia foi publicado em 1991. É um ensaio clínico randomizado realizado em Jersusalém com 60 mulheres, que comparou a cola adesiva cirúrgica com o categute cromado, usando três grupos distintos: um grupo de mulheres com a pele da primeira 
episiotomia reparada com categute cromado, outro grupo com episiotomia de repetição reparado com categute cromado e o terceiro grupo com o reparo da pele de primeira episiotomia realizado com a cola adesiva. O objetivo do estudo foi avaliar a dor (Adoni, Anteby, 1991).

No referido estudo, a dor foi avaliada no segundo dia pós-parto com uma escala numérica de 1 a 5, em que 1 corresponde à menor dor e 5 ao máximo de dor. Foi perguntada a sensação dolorosa nas atividades cotidianas como caminhar, sentar, abaixar-se, amamentar, dormir, urinar e evacuar. Os autores encontraram diferença de dor no segundo dia pós-parto de 1,35 pontos no local da incisão, 1,85 pontos ao sentar, 1,35 pontos ao abaixar-se, 1,0 ponto ao caminhar e 0,7 pontos ao urinar, sempre indicando que as mulheres que tiveram a pele reparada com a cola adesiva cirúrgica sentiram menos dor. Nenhuma mulher submetida ao reparo com cola solicitou analgésicos, enquanto $40 \%$ das mulheres com o reparo da pele com categute cromado solicitaram (Adoni, Anteby, 1991).

Rogerson, Mason e Roberts (2000) também utilizaram a cola adesiva no reparo exclusivo da pele após o reparo das outras camadas com fio de sutura Vicryl em episiotomias e lacerações não complicadas de segundo grau. Em relação à dor, três mulheres referiram sensação de queimação no momento da aplicação e duas relataram sensação de uma ponta afiada no local da cola. Este último desfecho pode ocorrer devido ao fato de a cola endurecer na polimerização e, caso seja aplicada uma quantidade maior que a devida, excessos da cola podem causar desconforto na mulher.

Além dos dois estudos anteriores, Bowen e Selinger (2002) analisaram o reparo da pele em episiotomias, comparando a sutura (fio de ácido poliglicólico) com a cola adesiva cirúrgica (Histoacryl@). Foi utilizada uma escala numérica de 1 a 10 (1 menor dor e 10 a pior dor) e foram avaliadas atividades diárias, observando-se menor escore de dor em mulheres com o reparo realizado com cola adesiva cirúrgica. As atividades com diferença estatisticamente significantes foram urinar no primeiro e terceiro dias, com diferença de 1,8 e 1 pontos, respectivamente, ao caminhar no primeiro, segundo e quarto dias, com diferença de 1,$5 ; 1,3$ e 0,7 pontos, respectivamente, e ao evacuar no terceiro e quarto dias com diferença de 2,1 e 1,6 pontos, respectivamente. As mulheres do grupo experimental (cola) também demoraram menos tempo para deixar de sentir dor, comparadas às mulheres do grupo 
controle (fio) (18 versus 25 dias), assim como para a primeira relação sexual sem dor (34 versus 52 dias).

Mota et al. (2009) realizaram o mesmo procedimento dos autores citados acima, com o reparo apenas na pele em episiotomias, com a sutura com poliglactina 910 rapidamente absorvível e cola adesiva cirúrgica octil-2-cianoacrilato. Contrapondo aos achados dos estudos citados anteriormente, os autores não encontraram diferença significativa entre os grupos no quesito dor.

O estudo mais recente comparando a cola adesiva cirúrgica (Dermabond®) e fio Vicryl Rapide® para o reparo da pele em episiotomias foi conduzido por Chamariya, Prasad e Chauhan (2016). O resultado indicou que $16 \%$ das mulheres relataram dor durante o procedimento de reparo da pele com cola adesiva, enquanto $72 \%$ das mulheres relataram dor durante o reparo da pele com fio de sutura.

Em relação à avaliação da dor no seguimento pós-parto (aferida por uma escala de 0 a 5 , em que 0 se refere a nenhuma dor e 5 o máximo de dor possível), foi encontrada diferença de 0,82 pontos no momento do procedimento, 0,66 pontos no primeiro dia pós-parto, 0,52 pontos no segundo dia pós-parto e 0,38 no terceiro dia pós-parto, indicando menor dor nas mulheres com reparo realizado por cola adesiva.

Em relação aos estudos apresentados acima, todos compararam o reparo da pele em episiotomias ou lacerações de segundo grau. Sob este ponto de vista, é importante expor algumas observações relacionadas ao tipo de material utilizado, método de mensuração da dor, momento em que a dor foi mensurada e custos do procedimento.

Claramente, os estudos apresentam metodologias distintas, o que pode justificar as diferenças encontradas nos resultados. Nos estudos apresentados, foram utilizados no grupo controle os fios de sutura categute cromado (Adoni, Anteby, 1991), poliglactina (Bowen, Selinger, 2002; Rogerson, Mason, Roberts, 2000) e poliglactina de rápida absorção (Chamariya, Prasad, Chauhan, 2016; Mota et al., 2009). A utilização de fios de suturas distintos e de diâmetros variáveis pode ter influenciado na diferença de dor encontrada, além da possibilidade da dor estar relacionada justamente com diferentes camadas reparadas com fio.

Além dos tipos distintos de fios, os estudos também não foram uniformes no tipo de cola à base de cianoacrilato utilizada. Bowen e Selinger (2002), Rogerson, Mason e Roberts 
(2000) e Adoni e Anteby (1991) utilizaram n-butil-cianoacrilato (Histoacryl@ ou Indermil@), enquanto Chamariya, Prasad e Chauhan (2016) e Mota et al. (2009) utilizaram octil-2cianoacrilato (Dermabond $®$ ). Sob este aspecto, vale ressaltar que dos estudos que utilizaram a cola adesiva n-butil-cianoacrilato, dois avaliaram a dor no momento do reparo (Feigenberg et al., 2014; Rogerson, Mason, Roberts, 2000) e ambos apontaram que as mulheres relataram "sensação de queimadura" e "calor desagradável" no momento de aplicação da cola. Devido à queixa de calor desagradável no momento da aplicação, Feigenberg et al. (2014) excluíram essa cola do seu estudo, após o término do piloto.

Sobre os estudos que utilizaram octil-2-cianoacrilato (Chamariya, Prasad, Chauhan, 2016; Feigenberg et al. 2014; Mota et al., 2009), todos avaliaram a dor no momento do reparo e nenhum relatou sensação de calor desagradável.

Pode-se notar que há uma diferença entre os tipos de cola adesiva cirúrgica à base de cianoacrilato, de acordo com as cadeias de alquilo, podendo promover maior conforto ou desconforto no momento do reparo. No presente estudo, utilizou-se outro tipo de cola, a etil2-cianoacrilato (Epigluß) e não houve relatos de sensação de calor desagradável no momento da aplicação. Tal calor se deve ao fato de a polimerização da cola adesiva ocorrer através de uma reação exotérmica. Desse modo, é importante que os fabricantes informem a temperatura que a cola adesiva atinge na polimerização, para evitar desfechos como os apresentados nos estudos anteriores ou lesão dos tecidos.

O único estudo que avaliou o reparo de lacerações de primeiro grau sem sutura adicional foi o de Feigenberg et al. (2014). Os autores analisaram a dor através de uma escala de 0 a 10 pontos ( 0 sem dor e 10 o máximo de dor). No momento imediato ao reparo, as mulheres do grupo controle (fio) apresentaram média de dor de 4,14 pontos, enquanto que aquelas do grupo experimental (cola) apresentaram o score de 1,72, ou seja, uma diferença de 2,42 pontos.

No presente estudo, a avaliação da dor ocorreu em quatro momentos distintos. Imediatamente após o parto foi solicitado à mulher que através da EVN apontasse de 0 a 10 , referente ao momento do reparo. O motivo de perguntar a dor logo após o reparo foi o de explorar se a cola adesiva cirúrgica etil-2-cianoacrilato no momento da aplicação apresentava efeitos adversos, como relatado em estudos anteriores com a n-butil-2-cianoacrilato. Isso 
difere do estudo de Feigenberg et al. (2014), em que foi solicitado à mulher referir a dor posteriormente, e não no momento do procedimento.

A média do escore de dor no momento do reparo foi de 0,4 entre as mulheres do grupo experimental (cola) e 2,4 entre aquelas do grupo controle (fio), ou seja, uma diferença de dois pontos. Estes valores são menores que os encontrados por Feigenberg et al. (2014) e isso pode ser atribuído ao fato do presente estudo possuir um número amostral reduzido, ao fato de serem colas adesivas distintas ou à possibilidade de as mulheres referirem outro escore de dor entre o momento do procedimento e após o procedimento.

A diferença dos escores de dor na segunda etapa (de 12 a 24 horas após o parto) foi de 0,5 pontos, na terceira etapa (36 a 48 horas após o parto) de 1,7 pontos e na quarta etapa (10 a 20 dias) de 0,4 pontos, sempre apontando o menor escore de dor entre as mulheres do grupo experimental.

De modo geral, na maioria dos estudos existe uma tendência ou diferença significante, com menores escores de dor para os grupos experimentais, ou seja, grupos que realizaram o reparo com cola adesiva cirúrgica, seja apenas na pele da episiotomia ou laceração de segundo grau ou no reparo de lacerações de primeiro grau. É importante uma análise para verificar se as diferenças estatisticamente encontradas refletem de fato uma diferença clínica relevante nos escores de dor que justifique o uso da cola adesiva cirúrgica. Além desse fato, é importante realizar um estudo econômico para avaliar o custo-benefício do uso da cola adesiva cirúrgica. Embora o custo da cola seja superior ao custo do fio de sutura, o reparo com cola dispensa o uso de anestésico local, seringas e agulhas, além do tempo de procedimento ser reduzido.

\subsection{AVALIAÇÃO DO PROCESSO DE CICATRIZAÇÃO}

Os estudos que avaliaram ou citaram em algum momento informações sobre o processo de cicatrização da sutura foram Chamariya, Prasad, Chauhan (2016), Feigenberg et al. (2014), Mota et al.(2009), Bowen e Selinger (2002) e Rogerson, Mason e Roberts (2000).

No estudo de Rogerson, Mason e Roberts (2000) foi relatada a queda de duas películas de cola adesiva antes da alta, ou seja, as mulheres receberam alta com a pele sem reparo devido à eliminação da cola; entretanto, na reavaliação realizada 5 semanas após o parto, 
ambas tinham a pele completamente cicatrizada, sem necessidade de reparo adicional. Em outros dois casos, foram analisados defeitos de aposição da pele 2 semanas após o parto; entretanto, em 6 semanas pós-parto, a pele estava cicatrizada, sem necessidade de tratamento. Os autores também relatam que foi utilizado o tratamento com nitrato de prata em uma ferida em 6 semanas pós-parto, mas não apresentaram a causa e referem a cicatrização total da pele, sem necessidade de reparo adicional.

Assim como referido acima, a queda precoce da cola adesiva cirúrgica também foi notada no presente estudo. Isso ocorreu no período em que ainda se estava mensurando a quantidade ideal de cola adesiva a ser aplicada para o reparo. Quando uma quantidade maior de cola foi aplicada, ela se desprendeu da pele ou mucosa, havendo necessidade de reaplicação, no mesmo momento, em menor quantidade. Ou seja, o desprendimento da cola durante o reparo perineal está relacionado à quantidade de cola aplicada.

Bowen e Selinger (2002) relatam que dentre as 62 mulheres incluídas no estudo, nenhuma apresentou deiscência da ferida ou solicitou que a sutura fosse removida. Mota et al. (2009) e Feigenberg et al. (2014) não apresentaram diferença em complicações ou resultados cosméticos entre os grupos experimental e controle. Chamariya, Prasad e Chauhan (2016) também não encontraram diferença significativa no resultado da cicatrização das feridas e complicações entre os grupos. Entretanto, o grupo experimental levou 4 dias para cicatrização, enquanto o grupo controle demorou 8 dias para completar a cicatrização.

No presente estudo, não houve diferenças estatisticamente significantes entre os grupos, apesar de a equimose estar presente somente nas lacerações reparadas com o fio de sutura. A coaptação das bordas chamou a atenção, pois apesar de inicialmente estar menor no grupo experimental, na última etapa apresentava-se maior neste grupo. 


\subsection{AVALIAÇÃO DO TEMPO DE REPARO}

Alguns estudos utilizaram o tempo de reparo como medida de desfecho. Desses, Rogerson, Mason e Roberts (2002) não apresentaram o tempo de reparo. Porém, referiram que o tempo de reparo com a cola adesiva cirúrgica foi ligeiramente mais rápido, quando o

local do reparo não estava úmido, entretanto, referem que houve algumas dificuldades no reparo quando havia sangramento ou grande umidade.

Mota et al. (2009) compararam o tempo de reparo total e encontraram diferença estatisticamente significante. $\mathrm{O}$ reparo da episiotomia com fio de sutura durou em média 23 minutos, enquanto o procedimento de reparo da pele da episiotomia com cola adesiva cirúrgica durou em média 19 minutos.

Chamariya, Prasad e Chauhan (2016) compararam o tempo de sutura de músculo e mucosa entre os grupos e não encontrou diferenças. Já o tempo de reparo da pele foi de 3,52 minutos com a sutura e 1,16 minutos com o adesivo cirúrgico; uma diferença de 1,36 minutos.

A pesquisa mais adequada para comparar tempo de sutura com o presente estudo é a de Feigenberg et al. (2014), uma vez que ambos comparam lacerações perineais de primeiro grau. Os autores encontraram diferença significativa de 5,59 minutos, com vantagem do grupo da cola adesiva cirúrgica. $\mathrm{O}$ tempo médio para cada reparo foi de 7,88 minutos para fio de sutura e 2,29 minutos para cola adesiva.

O presente estudo teve um tempo médio de reparo maior que o encontrado por Feigenberg et al. (2014). Isso pode estar relacionado com a complexidade das lacerações, bem como com a habilidade do profissional que realizou o reparo em cada estudo. A diferença de média encontrada foi de 16 minutos, sendo que a média do tempo de reparo no grupo experimental foi de 5 minutos e no grupo controle foi 21 minutos.

\subsection{AVALIAÇÃO DA SATISFAÇÃO DAS MULHERES}

Feigenberg et al. (2014) são os únicos autores que relatam avalição da satisfação das mulheres em relação ao reparo perineal e não encontraram diferença estatística, uma vez que ambos os grupos apresentaram uma alta satisfação. 
Neste estudo, todas as mulheres submetidas ao reparo com cola adesiva cirúrgica se consideraram muito satisfeitas ou satisfeitas, ao passo que $10 \%$ a $20 \%$ das mulheres do grupo controle estavam insatisfeitas ou muito insatisfeitas.

\subsection{LIMITAÇÕES E FORTALEZAS}

O presente estudo foi planejado para determinar a viabilidade de um ensaio clínico aleatorizado para avaliar a efetividade da cola adesiva etil-2-cianoacrilato no reparo de lacerações perineais de primeiro grau durante o parto e, apesar do tamanho limitado da amostra que impede a generalização dos dados, mostrou performance adequada a um estudo piloto.

Uma fortaleza foram os critérios de inclusão e exclusão das participantes, definidos para minimizar o viés de seleção e, ao mesmo tempo, favorecer a elegibilidade das participantes e ampliar o caráter pragmático do ensaio clínico aleatorizado.

Outra fortaleza foi a adesão das mulheres ao estudo, com apenas uma recusa em participar e uma única perda de seguimento na etapa 4 (10 a 20 dias após o parto), realizada após a alta hospitalar.

Como limitação, vale destacar a dificuldade de recrutamento das mulheres durante a gestação. As consultas de pré-natal são realizadas em serviços dispersos por todo o município e o local do estudo não é o único serviço de referência para realização de partos normais. Portanto, as mulheres recrutadas para pesquisa estavam internadas no CPN, momento em que era possível convidá-las para realização da pesquisa.

\subsection{IMPLICAÇÕES PARA PESQUISA}

Este estudo piloto apresenta-se como base para outros estudos e ensaios clínicos, uma vez que traz um compilado dos estudos existentes sobre a técnica de reparo estudada, além do fato de servir como base para o cálculo amostral de um futuro ensaio clínico aleatorizado.

Novos estudos explorando o custo-benefício desta técnica são incentivados, assim como estudos em lacerações perineais de maior complexidade. 


\subsection{IMPLICAÇÕES PARA PRÁTICA}

Lacerações perineais de primeiro grau possuem boa cicatrização e geralmente não necessitam de reparo por cicatrizarem sem maiores problemas. Entretanto, algumas possuem indicações de sutura devido à deformidade anatômica ou sangramento excessivo, mesmo após medidas de contenção. Nestes casos, a cola adesiva cirúrgica apresenta-se como uma alternativa para redução do tempo de reparo, menor dor e maior satisfação da mulher, em especial quando o parto ocorre de forma natural, sem analgesia.

Novos estudos devem ser conduzidos para corroborar estes achados. 


\section{CONCLUSÃO}




\section{CONCLUSÃO}

Este estudo mostrou que é viável realizar um ensaio clínico controlado e aleatorizado sobre o uso da cola adesiva cirúrgica Epiglu® para o reparo de lacerações perineais de primeiro grau durante o parto normal que inclua o mesmo período de seguimento, bem como os mesmos desfechos analisados neste piloto (dor perineal e cicatrização, satisfação das mulheres e tempo de reparação).

O estudo mostrou ainda que é viável adotar a técnica de reparo com Epiglu@, utilizada no estudo piloto.

Além disso, os resultados foram importantes para comparar os métodos de reparo perineal e calcular o tamanho da amostra para o ensaio clínico aleatorizado.

Ao mesmo tempo, levantou estudos e discussões sobre as novas tecnologias para o reparo perineal, expondo lacunas do conhecimento para futuras pesquisas. 
8 REFERÊNCIAS 


\section{REFERÊNCIAS}

Adoni A, Anteby E. The use of Histoacryl for episiotomy repair. BJOG. 98:476-8.

Andrade JNBM, Cuevas SE; Maniscalco CL, Stefanes SA. Uso do etil-cianoacrilato na síntese da parede vascular em cães. Ars Veterinária. 2001;17(3):172-6.

Atalah ES, Castillo C, Castro R, Aldea A. Propuesta de un nuevo estándar de evaluación nutricional en embarazadas. Rev Med Chile. 1997;125(12):1429-36.

Berger A, Worly YB. Clitoral avulsion successfully repaired with 2octylcyanoacrylate. J Sex Med. 2013;10(7):1889-92.

Bols EM, Hendricks EJ, Berghmans BC, Baeten CG, Nijhuis JG, de Bie RA. A systematic review of etiological factors for postpartum fecal incontinence. Acta Obstet Gynecol Scand. 2010;89(3):302-14.

Bowen ML, Selinger M. Episiotomy closure comparing enbucrilate tissue adhesive with conventional sutures. Int J Gynaecol Obstet 2002;78:201-5.

Boyle M. Wound healing in midwifery. Oxford: Radcliffe; 2006.

Brasil. Ministério da Saúde, Secretaria da Ciência, Tecnologia e Insumos Estratégicos. Departamento de Ciência e Tecnologia. PNDS 2006: Pesquisa Nacional de Demografia e Saúde da Criança e da Mulher: relatório. Brasília: Ministério da Saúde; 2008.

Brasil. Ministério da Saúde. Comissão Nacional de Incorporação de Tecnologias no SUS. Diretriz Nacional de Assistência ao Parto Normal [Internet]. CONITEC (BR) 2016;

Disponível em: http://conitec.gov.br/images/Consultas/2016/Relatorio_DiretrizPartoNormal_CP.pdf

Cabar FR, Codarin RR, Bundunki V. Anatomia e fisiologia: anatomia da pelve feminina. In: Zugaib M, editor, Francisco RPV, editor. Obstetrícia. $3^{a}$ ed. São Paulo: Manole; 2016. p.36-42.

Chamariya S, Prasad M, Chauhan A. Comparison of dermabond adhesive glue with skin suture for repair of episiotomy. Int J Reprod Contracept Obstet Gynecol. 2016;5(10):34615.

Declercq E, Cunningham DK, Johnson C, Sakala C. Mothers' reports of postpartum pain associated with vaginal and cesarean deliveries: results of a national survey. Birth.

2008;35:16-24.

Dehne $\mathrm{T}$ et al. A method to screen and evaluate tissue adhesives for joint repair applications. BMC Musculoskelet Disord. 2012;13(175): 1-9. 
Dumville JC, et al. Tissue adhesives for closure of surgical incisions. Cochrane Database of Syst Rev. 2014;(8) Art. No. CD004287. DOI: 10.1002/14651858.CD004287.pub4.

Elharmeel SM, Chaudhary Y, Tan S, Scheermeyer E, Hanafy A, van Driel ML. Surgical repair of spontaneous perineal tears that occur during childbirth versus no intervention. Cochrane Database of Syst Rev. 2011;(8), Art. No. CD008534. DOI: 10.1002/14651858.CD008534.pub2.

Eshkevari L, Trout KK, Damore J. Management of postpartum pain. J Midwifery Womens Health. 2013;56(8):622-31.

Feigenberg T, Maor-Sagie E, Zivi E, Abu-Dia M, Ben- Meir A, Sela HY, et al. Using adhesive glue to repair first degree perineal tears: a prospective randomized controlled trial. Bio Med Res Int 2014;(2014):1-5.

Fernando R, Sultan AH, Kettle C, Thaka R. Methods of repair for obstetric anal sphincter injury. Cochrane Database Syst Rev [internet]. 2013. Avaliable from:

http://www.cochrane.org/CD002866/PREG_methods-of-repair-for-obstetric-analsphincter-injury.

Fernando R, Sultan AH, Kettle C, Thakar R. Methods of repair for obstetric anal sphincter injury. Cochrane Database of Syst Rev. 2013;(12) Art. No.: CD002866. DOI: 10.1002/14651858.CD002866.pub3

Fischl RA. An adhesive for primary closure of skin incisions: a preliminary report. Plastic and Reconstructive Surgery. 1962;30(5):607-10.

Flanagan M. A practical framework for wound assessment. Physiology: part one. British Journal of Nursing. 1996;5(22):1391-7.

Frohlich J, Kettle C. Perineal care. BMJ Clin Evid. 2015;3:1401.

García Cerdá D, Ballester AM, Aliena-Valero A, Carabén-Redaño A, Lloris JM. Use of cyanoacrylate adhesives in general surgery. Surgery Today. 2015;45(8):939-56.

Gosling JA, Dixon JS, Critchley HOD, Thompson AS. A comparative study of the human external sphincter and periurethral levator ani muscles. Br J Urol. 1981;53:35-41.

Henderson C, MacDonald S. Mayes midwifery: a textbook for midwives. $13^{\mathrm{a}}$ ed. Edinburgh: Baillière Tindall; 2006.

Hill PD. Psycometric properties of the REEDA. J Nurse Midwifery. 1990;35(3):162-5.

Hjermstad MJ, Fayers PM, Haugen DF, Caraceni A, Hanks GW, Loge JH, et al. Studies comparing numerical rating scales, verbal rating scales, and visual analog scales for 
assessment of pain intensity in adults: a systematic literature review. J Pain Symptom Manage. 2011;41(6):1073-93.

Ismail KMK, Israfilbayli F, Toozs-Hobson P, Kettle C. Suturing versus alternative closure techniques for repair of episiotomy or second degree perineal. Cochrane Database of Syst Rev. 2013;(4) Art. No. CD010486. DOI: 10.1002/14651858.CD010486.

Kettle C, Dowswell T, Ismail KMK. Continuous and interrupted suturing techniques for repair of episiotomy or second-degree tears. Cochrane Database of Syst Rev. 2012;(11) Art. No. CD000947. DOI: 10.1002/14651858.CD000947.pub3.

Kreling MC, Cruz DA, Pimenta CA. Prevalence of chronic pain in adult workers. Rev Bras Enferm. 2006;59(4):509-13.

Leal MC, Pereira APE, Domingues RMSM, Filha MMT, Dias MAB, Nakamura-Pereira M, et al. Intervenções obstétricas durante o trabalho de parto e parto em mulheres brasileiras de risco habitual. Cad. Saúde Pública [Internet]. 2014 [acessado em 24 de janeiro de 2018]. Disponível em: http://www.scielo.br/scielo.php?script=sci_arttext\&pid=S0102$311 X 2014001300005 \& \operatorname{lng}=$ en.

Li J, Chen J, Kirsner R. Pathophysiology of acute wound healing. Clin Dermatol. 2007;25(1):9-18.

Metcalfe AM, Tohill S, Williams A, Haldon V, Brown L, Henry L. Developing a pragmatic tool to measure second-degree perineal tears. Br J Midwifery.2002;10(7):412-17.

Mota R, Costa F, Amaral A, Oliveira F, Santos CC, Ayres-De Campos D. Skin adhesive versus subcuticular suture for perineal skin repair after episiotomy: a randomized controlled trial. Acta Obstet Gynecol Scand. 2009;88(6):660-6.

NICE, National Institute for Health and Care Excellence [Internet]. Intrapartum care for healthy women and babies: clinical guideline. Reino Unido. 2014. Disponível em: https://www.nice.org.uk/guidance/cg190/resources/intrapartum-care-for-healthy-womenand-babies-pdf-35109866447557

Oldfield A. Assessing the open surgical wound. Wound Essentials. 2010;5:48-56.

Papatheofanis FJ; Barmada R. The principles and applications of surgical adhesives. Surg Annu. 1993;25(1):49-81.

Reinke JM, Sorg H. Wound repair and regeneration. Eur Surg Res. 2012;49(1):35-43.

Rezende Filho J, editor, Montenegro CAB, editor. Obstetrícia fundamental. $13^{\mathrm{a}}$ ed. Rio de Janeiro: Guanabara Koogan; 2014. 
Riesco MLG, Costa ASC, Almeida SFS, Basile ALO, Oliveira SMJV. Episiotomia, laceração e integridade perineal em partos normais: análise de fatores associados. Rev Enferm UERJ. 2011;19(1):77-83.

Rogerson L, Mason GC, Roberts AC. Preliminary experience with twenty perineal repairs using Indermil tissue adhesive. Eur J Obstet Gynecol Reprod Biol. 2000;88:139-42.

Seijmonsbergen-Schermers AE, Sahami S, Lucas C, Jonge A. Nonsuturing or skin adhesives versus suturing of the perineal skin after childbirth: a systematic review. Birth 2015;42(2):100-15.

Smith LA, Price N, Simonite V, Burns E. Incidence of and risk factors for perineal trauma: a prospective observational study. BMC Pregnancy Childbirth. 2013;13(59):1-9.

Steen M. Perineal tears and episiotomy: how do wounds heal?.Br J Midwifery. 2007;15(5):273-80.

Strong J, Unruh AM, Wright A, Baxter GD. Pain assessmente and measurement. In: Pain: a textbook for therapists. London; 2001.

Sultan AH. Editorial: Obstetrical perineal injury and anal incontinence. Clin Risk. 1999;(5):193-6.

Thakar R, Sultan, AH. Perineal and anal sphincter trauma. London: Springe; 2009.

Trout KK. The neuromatrix theory of pain: implications for selected nonpharmacologic methods of pain relief for labor. J Midwifery Womens Health. 2004;49(6):482-8.

Twaddle ML, Cooke KJ. Avaliação da dor e síndromes dolorosas comuns. In: Von Roenn, JH, Paice JA, Preodor ME. Current dor diagnóstico e tratamento. Porto Alegre: McGrawHill1; 2011.p.10-20.

Vuolo JC. Assessment and management of surgical wounds in clinical practice. Nurs Stand. 2006;20(52):46-56. 


\section{APÊNDICE A}

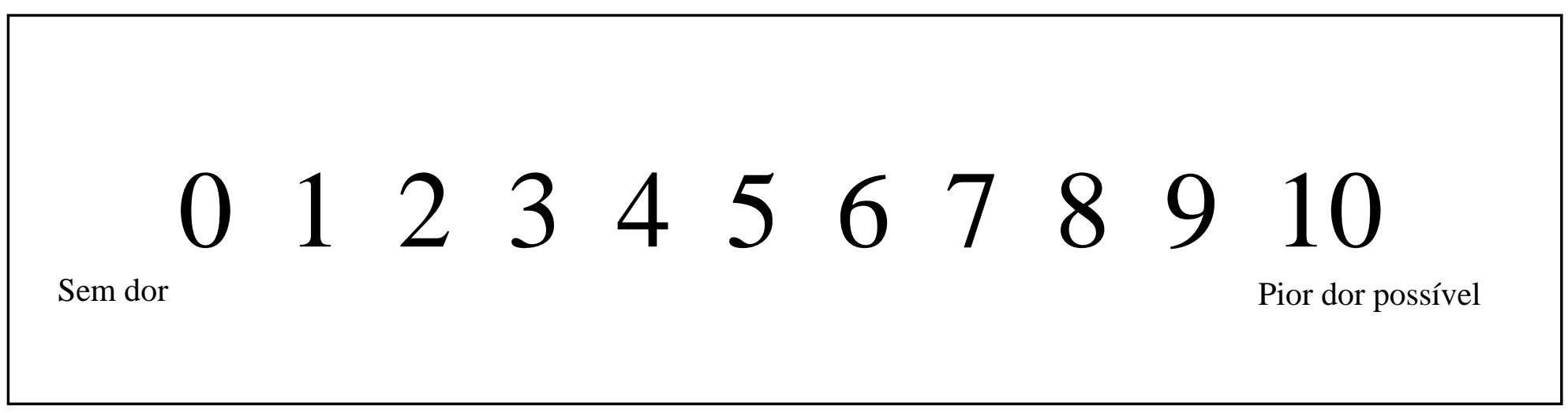


APÊNDICE B

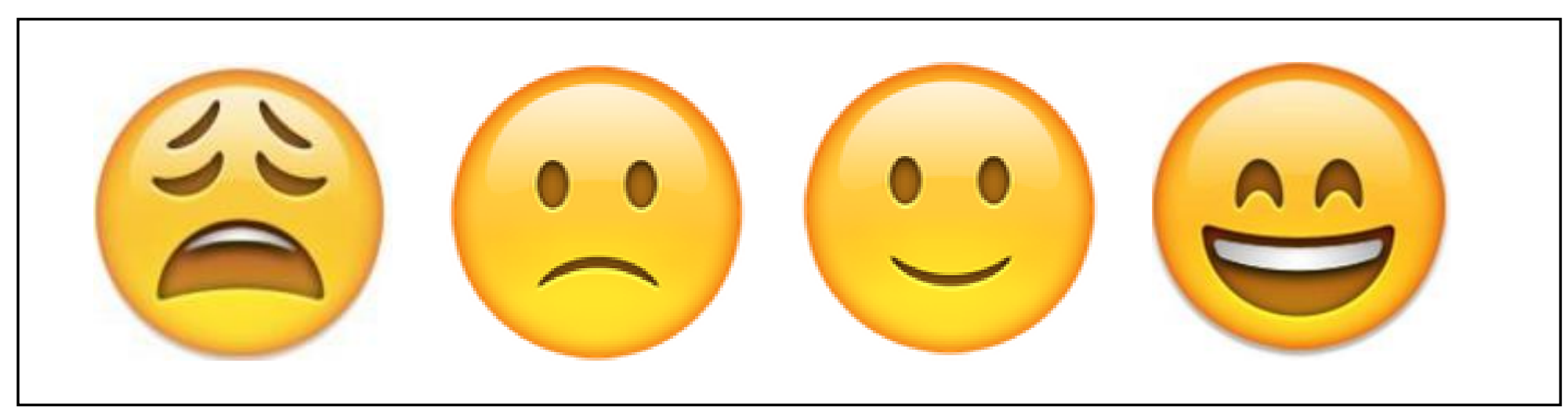




\begin{abstract}
APÊNDICE C
INSTRUMENTO PARA COLETA DE DADOS N ${ }^{\circ}$
\end{abstract}

Grupo: 0 [ ] cola adesiva

Grupo: 1 [ ] fio de sutura

Identificação

Nome:

Telefone: ( ) / ( ) recado com:

Número do Prontuário:

1a Etapa (internação) - data

Hora __:

1. Idade [_] [_] anos

2. Cor da pele

0 [ ] branca

1 [ ] parda

2 [ ] preta

3 [ ] amarela

4 [ ] indígena

3. Escolaridade

0 [ ] nenhuma

1 [ ] fundamental incompleto

2 [ ] fundamental completo ou médio incompleto

3 [ ] médio completo ou superior incompleto

4 [ ] superior completo

4. Ocupação

0 [ ] trabalho remunerado

1 [ ] do lar

2 [ ] estudante

5. Situação conjugal

0 [ ] não vive com parceiro

1 [ ] vive com parceiro

6. Número de partos vaginais anteriores [_] [_]

7. Trauma perineal com sutura em parto anterior

0 [ ] não

$1[$ ] $\operatorname{sim}$

8. DMG

0 [ ] não

$1[$ [ $\operatorname{sim}$ 
9. IG (DUM) [_] [_] semanas

9.a. IG(USG) [_][_] semanas

9.b. IG Capurro (se DUM e USG incompatíveis) [_][_] semanas

10. Peso [_] [_] $][],\left[\_\right] \mathrm{kg}$

11. Estatura [_], [_] $[\ldots] \mathrm{m}$

12. Presença de acompanhante no parto

0 [ ] não

1 [ ] $\operatorname{sim}$

13. Data do parto

14. Hora do parto

15. Tempo entre a internação e o parto [_] horas [_ _ ] minutos

16. Tempo de bolsa rota [_] horas [_] minutos

17. Uso de antibiótico intraparto

0 [ ] não

$1[$ ] $\operatorname{sim}$

18. Uso de anti-inflamatório após o parto

0 [ ] não

1 [ ] sim. Horário

19. Uso de analgésico após o parto

0 [ ] não

1 [ ] sim. Horário

20. Peso RN: [__ [__ ] _ $][\ldots]$ gramas

21. Perímetro cefálico RN [_] [_] centímetros

22. Tipo de laceração

0 [ ] única

1 [ ] múltipla

23. Laceração no clitóris

0 [ ] não

1 [ ] sim 


\section{Laceração na região vestibular}

0 [ ] não

$1[$ ] $\operatorname{sim}$

25. Laceração em pequenos lábios

0 [ ] não

$1[$ ] $\operatorname{sim}$

26. Laceração em mucosa vaginal

0 [ ] não

$1[$ ] $\operatorname{sim}$

27. Laceração no corpo perineal

0 [ ] não

$1[$ ] sim

28. Tempo de reparo em minutos [_] $\left[\_\right]$minutos

29. Dor perineal: escala visual numérica

\begin{tabular}{|llllllllll|}
\hline $\begin{array}{l}0 \\
\text { Sem dor }\end{array}$ & 1 & 2 & 3 & 4 & 5 & 6 & 7 & 8 & $9 \begin{array}{c}10 \\
\text { Pior dor possível }\end{array}$ \\
\hline
\end{tabular}

30. Satisfação da mulher

3 [ ] muito satisfeita

2 [ ] satisfeita

1 [ ] pouco satisfeita

0 [ ] insatisfeita 


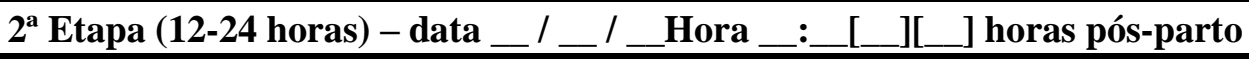

31. Dor perineal: escala visual numérica

\begin{tabular}{|lllllllllll|}
\hline \begin{tabular}{l} 
Sem dor \\
\hline
\end{tabular} & 1 & 2 & 3 & 4 & 5 & 6 & 7 & 8 & $9 \begin{array}{c}10 \\
\text { Pior dor possível }\end{array}$ \\
\hline
\end{tabular}

\section{Processo de cicatrização perineal: escala REEDA}

\begin{tabular}{|c|c|c|c|c|c|}
\hline Pontos & Hiperemia & Edema & Equimose & Secreção & Coaptação \\
\hline 0 & Nenhuma & Nenhum & Nenhuma & Nenhuma & Fechada \\
\hline 1 & $\begin{array}{l}\text { Até } 0,25 \mathrm{~cm} \text { da } \\
\text { incisão } \\
\text { bilateralmente }\end{array}$ & $\begin{array}{l}\text { Perineal a } \\
\text { menos de } 1 \mathrm{~cm} \\
\text { a partir da } \\
\text { incisão }\end{array}$ & $\begin{array}{l}\text { Até } 0,25 \mathrm{~cm} \text { da } \\
\text { incisão } \\
\text { bilateralmente } \\
\text { ou } 0,5 \mathrm{~cm} \\
\text { unilateralmente }\end{array}$ & Serosa & $\begin{array}{l}\text { Pele separada } 3 \\
\text { mm ou menos }\end{array}$ \\
\hline 2 & $\begin{array}{l}\text { Até } 0,5 \mathrm{~cm} \text { da } \\
\text { incisão } \\
\text { bilateralmente }\end{array}$ & $\begin{array}{l}\text { Perineal ou } \\
\text { vulvar de 1-2 } \\
\text { cm da incisão }\end{array}$ & $\begin{array}{l}\text { Entre } 0,25 \mathrm{~cm} \text { e } \\
1 \mathrm{~cm} \\
\text { bilateralmente } \\
\text { ou entre } 0,5-2 \\
\mathrm{~cm} \\
\text { unilateralmente }\end{array}$ & Serosanguínea & \begin{tabular}{|l} 
Pele e \\
subcutâneo \\
separados
\end{tabular} \\
\hline 3 & $\begin{array}{l}\text { Além de } 0,5 \mathrm{~cm} \\
\text { da incisão } \\
\text { bilateralmente }\end{array}$ & $\begin{array}{l}\text { Perineal ou } \\
\text { vulvar além de } \\
2 \mathrm{~cm} \text { da incisão }\end{array}$ & $\begin{array}{l}\text { Além de } 1 \mathrm{~cm} \\
\text { bilateralmente } \\
\text { ou } 2 \mathrm{~cm} \\
\text { unilateralmente }\end{array}$ & $\begin{array}{l}\text { Sanguinolenta, } \\
\text { purulenta }\end{array}$ & $\begin{array}{l}\text { Pele, } \\
\text { subcutâneo e } \\
\text { músculo } \\
\text { separados }\end{array}$ \\
\hline Escore & & & & & \\
\hline
\end{tabular}

\section{Satisfação da mulher}

3 [ ] muito satisfeita

2 [ ] satisfeita

1 [ ] pouco satisfeita

0 [ ] insatisfeita

\section{Uso de anti-inflamatório após o parto}

0 [ ] não

1 [ ] sim. Horário

\section{Uso de analgésico após o parto}

0 [ ] não

1 [ ] sim. Horário 


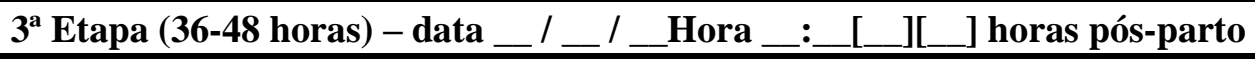

36. Dor perineal: escala visual numérica

\begin{tabular}{|lllllllllll|}
\hline \begin{tabular}{l} 
Sem dor \\
\hline
\end{tabular} & 1 & 2 & 3 & 4 & 5 & 6 & 7 & 8 & $9 \begin{array}{c}10 \\
\text { Pior dor possível }\end{array}$ \\
\hline
\end{tabular}

\section{Processo de cicatrização perineal: escala REEDA}

\begin{tabular}{|c|c|c|c|c|c|}
\hline Pontos & Hiperemia & Edema & Equimose & Secreção & Coaptação \\
\hline 0 & Nenhuma & Nenhum & Nenhuma & Nenhuma & Fechada \\
\hline 1 & $\begin{array}{l}\text { Até } 0,25 \mathrm{~cm} \text { da } \\
\text { incisão } \\
\text { bilateralmente }\end{array}$ & $\begin{array}{l}\text { Perineal a } \\
\text { menos de } 1 \mathrm{~cm} \\
\text { a partir da } \\
\text { incisão }\end{array}$ & $\begin{array}{l}\text { Até } 0,25 \mathrm{~cm} \text { da } \\
\text { incisão } \\
\text { bilateralmente } \\
\text { ou } 0,5 \mathrm{~cm} \\
\text { unilateralmente }\end{array}$ & Serosa & $\begin{array}{l}\text { Pele separada } 3 \\
\text { mm ou menos }\end{array}$ \\
\hline 2 & $\begin{array}{l}\text { Até } 0,5 \mathrm{~cm} \text { da } \\
\text { incisão } \\
\text { bilateralmente }\end{array}$ & $\begin{array}{l}\text { Perineal ou } \\
\text { vulvar de 1-2 } \\
\text { cm da incisão }\end{array}$ & $\begin{array}{l}\text { Entre } 0,25 \mathrm{~cm} \text { e } \\
1 \mathrm{~cm} \\
\text { bilateralmente } \\
\text { ou entre } 0,5-2 \\
\mathrm{~cm} \\
\text { unilateralmente }\end{array}$ & Serosanguínea & \begin{tabular}{|l} 
Pele e \\
subcutâneo \\
separados
\end{tabular} \\
\hline 3 & $\begin{array}{l}\text { Além de } 0,5 \mathrm{~cm} \\
\text { da incisão } \\
\text { bilateralmente }\end{array}$ & $\begin{array}{l}\text { Perineal ou } \\
\text { vulvar além de } \\
2 \mathrm{~cm} \text { da incisão }\end{array}$ & $\begin{array}{l}\text { Além de } 1 \mathrm{~cm} \\
\text { bilateralmente } \\
\text { ou } 2 \mathrm{~cm} \\
\text { unilateralmente }\end{array}$ & $\begin{array}{l}\text { Sanguinolenta, } \\
\text { purulenta }\end{array}$ & $\begin{array}{l}\text { Pele, } \\
\text { subcutâneo e } \\
\text { músculo } \\
\text { separados }\end{array}$ \\
\hline Escore & & & & & \\
\hline & & & & \multicolumn{2}{|l|}{ Total } \\
\hline
\end{tabular}

\section{Satisfação da mulher}

3 [ ] muito satisfeita

2 [ ] satisfeita

1 [ ] pouco satisfeita

0 [ ] insatisfeita

\section{Uso de anti-inflamatório após o parto}

0 [ ] não

1 [ ] sim. Horário

\section{Uso de analgésico após o parto}

0 [ ] não

1 [ ] sim. Horário 


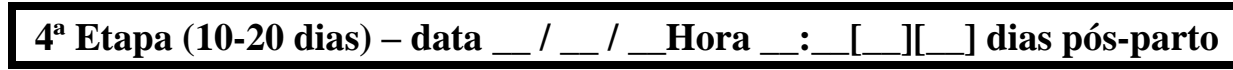

41. Dor perineal: escala visual numérica

\begin{tabular}{|lllllllllll|}
\hline $\begin{array}{l}\text { Sem dor } \\
\text { Sem }\end{array}$ & 1 & 2 & 3 & 4 & 5 & 6 & 7 & 8 & 9 & $\begin{array}{c}10 \\
\text { Pior dor possível }\end{array}$ \\
\hline
\end{tabular}

\section{Processo de cicatrização perineal: escala REEDA}

\begin{tabular}{|c|c|c|c|c|c|}
\hline Pontos & Hiperemia & Edema & Equimose & Secreção & Coaptação \\
\hline 0 & Nenhuma & Nenhum & Nenhuma & Nenhuma & Fechada \\
\hline 1 & $\begin{array}{l}\text { Até } 0,25 \mathrm{~cm} \text { da } \\
\text { incisão } \\
\text { bilateralmente }\end{array}$ & $\begin{array}{l}\text { Perineal a } \\
\text { menos de } 1 \mathrm{~cm} \\
\text { a partir da } \\
\text { incisão }\end{array}$ & $\begin{array}{l}\text { Até } 0,25 \mathrm{~cm} \text { da } \\
\text { incisão } \\
\text { bilateralmente } \\
\text { ou } 0,5 \mathrm{~cm} \\
\text { unilateralmente }\end{array}$ & Serosa & $\begin{array}{l}\text { Pele separada } 3 \\
\text { mm ou menos }\end{array}$ \\
\hline 2 & $\begin{array}{l}\text { Até } 0,5 \mathrm{~cm} \text { da } \\
\text { incisão } \\
\text { bilateralmente }\end{array}$ & $\begin{array}{l}\text { Perineal ou } \\
\text { vulvar de } \\
1-2 \mathrm{~cm} \text { da } \\
\text { incisão }\end{array}$ & $\begin{array}{l}\text { Entre } 0,25 \mathrm{~cm} \text { e } \\
1 \mathrm{~cm} \\
\text { bilateralmente } \\
\text { ou entre } 0,5-2 \\
\mathrm{~cm} \\
\text { unilateralmente }\end{array}$ & Serosanguínea & \begin{tabular}{|l} 
Pele e \\
subcutâneo \\
separados
\end{tabular} \\
\hline 3 & $\begin{array}{l}\text { Além de } 0,5 \mathrm{~cm} \\
\text { da incisão } \\
\text { bilateralmente }\end{array}$ & $\begin{array}{l}\text { Perineal ou } \\
\text { vulvar além de } \\
2 \mathrm{~cm} \text { da incisão }\end{array}$ & $\begin{array}{l}\text { Além de } 1 \mathrm{~cm} \\
\text { bilateralmente } \\
\text { ou } 2 \mathrm{~cm} \\
\text { unilateralmente }\end{array}$ & $\begin{array}{l}\text { Sanguinolenta, } \\
\text { purulenta }\end{array}$ & $\begin{array}{l}\text { Pele, } \\
\text { subcutâneo e } \\
\text { músculo } \\
\text { separados } \\
\end{array}$ \\
\hline Escore & & & & & \\
\hline & & & & \multicolumn{2}{|l|}{ Total } \\
\hline
\end{tabular}

\section{Satisfação da mulher}

3 [ ] muito satisfeita

2 [ ] satisfeita

1 [ ] pouco satisfeita

0 [ ] insatisfeita

\section{Uso de anti-inflamatório após o parto}

0 [ ] não

1 [ ] sim. Horário

\section{Uso de analgésico após o parto}

0 [ ] não

1 [ ] sim. Horário 


\section{APÊNDICE D \\ TERMO DE CONSENTIMENTO LIVRE E ESCLARECIDO (Participante com 18 anos de idade ou mais)}

Eu, Thaís Trevisan Teixeira, obstetriz e aluna do curso de Pós-Graduação nível mestrado da Escola de Enfermagem da Universidade de São Paulo, estou realizando a pesquisa "Ensaio clínico sobre o uso de adesivo cirúrgico no reparo de lacerações perineais de primeiro grau", para saber se o adesivo (ou cola cirúrgica) é eficaz para a cicatrização das lacerações perineais que podem acontecer no parto normal. Esta pesquisa pretende saber se o uso da cola cirúrgica promove menos dor no períneo, melhor cicatrização e maior satisfação em comparação à sutura com fio e agulha.

Você está sendo convidada a participar da pesquisa, como voluntária. Durante o parto, caso você tenha alguma laceração de primeiro grau (que atinge a pele e/ou a mucosa vaginal) e que precise de sutura, você será incluída em um dos dois grupos da pesquisa mediante a um sorteio. No grupo da cola cirúrgica, o reparo da laceração será feito com gotas de Epigluß. No grupo de sutura com fio e agulha, será usado o método tradicional, de pontos com Vicryl Rapide $^{\circledR}$. Caso você tenha outras lacerações mais profundas, de segundo ou terceiro graus, você não participará desta pesquisa e o reparo da laceração será realizado conforme o padrão da maternidade.

No máximo 2 horas após o reparo da laceração, realizaremos uma entrevista de duração aproximada de 5 minutos para que você nos relate a intensidade da dor e a sua satisfação quanto ao método de reparo. A região perineal será avaliada e fotografada antes e após o reparo perineal para melhor avaliação do períneo. Essa entrevista ocorrerá também no alojamento conjunto, no primeiro e no segundo dia de internação, com duração aproximada de 5 minutos. Depois da alta hospitalar, entre 10 a 20 dias pós-parto, realizaremos mais uma entrevista, avaliação do períneo e fotografia, com duração aproximada de 5 minutos. Esta etapa será realizada no Pronto Socorro e Maternidade Zoraide Eva das Dores ou na sua casa, como for mais conveniente para você.

Não haverá custo e nem pagamento pela sua participação. Porém, nos dias em que for solicitada sua presença além dos dias de internação, está garantido a você e ao seu acompanhante o ressarcimento de despesas tais como transporte e alimentação, caso refiram necessidade. Haverá indenização para eventuais danos decorrentes da pesquisa, comprovados legalmente.

Participando desta pesquisa você contribuirá para o avanço do conhecimento sobre a saúde materna e a qualidade do atendimento no parto, beneficiando as mulheres que passarão pela mesma situação. O benefício esperado é que com a cola cirúrgica não seja preciso usar anestesia local para o reparo perineal, que cause menos dor perineal no período pós-parto e maior satisfação com o resultado do reparo.

Os riscos previstos na pesquisa são uma possível reação inflamatória no local do reparo, a separação das beiradas da laceração e alergia ao material utilizado. Existe também algum risco previsto de falha do reparo com a cola e, nesse caso, o reparo será realizado com anestesia, fio e agulha. Pode ocorrer algum constrangimento com a fotografia da região perineal, mas nessa fotografia, você não será identificada, pois seu rosto não aparecerá. Se durante a entrevista, exame ou fotografia você tiver algum desconforto e constrangimento, 
será oferecido acolhimento, respeitando o seu desejo de aceitar ou não responder as perguntas, ser examinada e fotografada.

Caso você tenha alguma reação, independente do uso da cola ou fio cirúrgico, você terá a garantia de assistência e de cuidados oferecidos pela pesquisadora e por esta maternidade. Você também terá a garantia de assistência integral e gratuita pelo tempo que for necessário em caso de danos decorrentes direta ou indiretamente da sua participação do estudo.

Você tem o direito de receber informações e esclarecimentos de dúvidas em qualquer momento que desejar durante a pesquisa e tem a liberdade para recusar a participar, de retirar seu consentimento ou interromper a participação a qualquer momento, sem acarretar prejuízo no seu atendimento nesta maternidade.

Os resultados da pesquisa serão transformados em trabalhos científicos e apresentados em congressos e revistas da área da saúde. O seu nome não será identificado na divulgação dos resultados da pesquisa, pois as suas respostas e as fotografias serão analisadas em conjunto com as de outros participantes. Os dados e as imagens desta pesquisa serão guardados pela pesquisadora.

Você terá acesso à pesquisadora em qualquer etapa do estudo, que poderá ser encontrada no endereço: Av. Dr. Enéas de Carvalho Aguiar, 419 - Cerqueira César - São Paulo/SP, no telefone (11) 9737-99623, e-mail: thais.trevisan.teixeira@usp.br. Para alguma consideração ou dúvida sobre aspectos éticos dessa pesquisa, entre em contato com o Comitê de Ética em Pesquisa da Escola de Enfermagem da USP, situado no endereço: Av. Dr. Enéas de Carvalho Aguiar, 419 - Cerqueira César - São Paulo/SP; telefone (11) 3061-8858; e-mail: cepee@usp.br.

Caso você concorde participar, rubricar a primeira página e assinar este documento em duas vias, autorizando dessa forma que os dados colhidos sejam utilizados nesta pesquisa. Você receberá uma via e a outra ficará guardada com a pesquisadora.

Esta pesquisa atende todas as especificações da Resolução n. 466, de 12 de dezembro de 2012, do Conselho Nacional de Saúde, que aprova as diretrizes e normas regulamentadoras de pesquisas envolvendo seres humanos.

Itapecerica da Serra, de de

Nome completo da participante

Assinatura da participante

Assinatura da pesquisadora 


\section{APÊNDICE E}

\section{TERMO DE ASSENTIMENTO LIVRE E ESCLARECIDO (Participante menor de 18 anos de idade)}

Eu, Thaís Trevisan Teixeira, obstetriz e aluna do curso de Pós-Graduação nível mestrado da Escola de Enfermagem da Universidade de São Paulo, estou realizando a pesquisa "Ensaio clínico sobre o uso de adesivo cirúrgico no reparo de lacerações perineais de primeiro grau", para saber se o adesivo (ou cola cirúrgica) é eficaz para a cicatrização das lacerações perineais que podem acontecer no parto normal. Esta pesquisa pretende saber se o uso da cola cirúrgica promove menos dor no períneo, melhor cicatrização e maior satisfação em comparação à sutura com fio e agulha.

Você está sendo convidada a participar da pesquisa, como voluntária. Durante o parto, caso você tenha alguma laceração de primeiro grau (que atinge a pele e/ou a mucosa vaginal) e que precise de sutura, você será incluída em um dos dois grupos da pesquisa mediante a um sorteio. No grupo da cola cirúrgica, o reparo da laceração será feito com gotas de Epigluß. No grupo de sutura com fio e agulha, será usado o método tradicional, de pontos com Vicryl Rapide $^{\circledR}$. Caso você tenha outras lacerações mais profundas, de segundo ou terceiro graus, você não participará desta pesquisa e o reparo da laceração será realizado conforme o padrão da maternidade.

No máximo 2 horas após o reparo da laceração, realizaremos uma entrevista de duração aproximada de 5 minutos para que você nos relate a intensidade da dor e a sua satisfação quanto ao método de reparo. A região perineal será avaliada e fotografada antes e após o reparo perineal para melhor avaliação do períneo. Essa entrevista ocorrerá também no alojamento conjunto, no primeiro e no segundo dia de internação, com duração aproximada de 5 minutos. Depois da alta hospitalar, entre 10 a 20 dias pós-parto, realizaremos mais uma entrevista, avaliação do períneo e fotografia, com duração aproximada de 5 minutos. Esta etapa será realizada no Pronto Socorro e Maternidade Zoraide Eva das Dores ou na sua casa, como for mais conveniente para você.

Não haverá custo e nem pagamento pela sua participação. Porém, nos dias em que for solicitada sua presença além dos dias de internação, está garantido a você e ao seu acompanhante o ressarcimento de despesas tais como transporte e alimentação, caso refiram necessidade. Haverá indenização para eventuais danos decorrentes da pesquisa, comprovados legalmente.

Participando desta pesquisa você contribuirá para o avanço do conhecimento sobre a saúde materna e a qualidade do atendimento no parto, beneficiando as mulheres que passarão pela mesma situação. O benefício esperado é que com a cola cirúrgica não seja preciso usar anestesia local para o reparo perineal, que cause menos dor perineal no período pós-parto e maior satisfação com o resultado do reparo.

Os riscos previstos na pesquisa são uma possível reação inflamatória no local do reparo, a separação das beiradas da laceração e alergia ao material utilizado. Existe também algum risco previsto de falha do reparo com a cola e, nesse caso, o reparo será realizado com anestesia, fio e agulha. Pode ocorrer algum constrangimento com a fotografia da região perineal, mas nessa fotografia, você não será identificada, pois seu rosto não aparecerá. Se 
durante a entrevista, exame ou fotografia você tiver algum desconforto e constrangimento, será oferecido acolhimento, respeitando o seu desejo de aceitar ou não responder as perguntas, ser examinada e fotografada.

Caso você tenha alguma reação, independente do uso da cola ou fio cirúrgico, você terá a garantia de assistência e de cuidados oferecidos pela pesquisadora e por esta maternidade. Você também terá a garantia de assistência integral e gratuita pelo tempo que for necessário em caso de danos decorrentes direta ou indiretamente da sua participação do estudo.

Você tem o direito de receber informações e esclarecimentos de dúvidas em qualquer momento que desejar durante a pesquisa e tem a liberdade para recusar a participar, de retirar seu consentimento ou interromper a participação a qualquer momento, sem acarretar prejuízo no seu atendimento nesta maternidade.

Os resultados da pesquisa serão transformados em trabalhos científicos e apresentados em congressos e revistas da área da saúde. O seu nome não será identificado na divulgação dos resultados da pesquisa, pois as suas respostas e as fotografias serão analisadas em conjunto com as de outros participantes. Os dados e as imagens desta pesquisa serão guardados pela pesquisadora.

Você terá acesso à pesquisadora em qualquer etapa do estudo, que poderá ser encontrada no endereço: Av. Dr. Enéas de Carvalho Aguiar, 419 - Cerqueira César - São Paulo/SP, no telefone (11) 9737-99623, e-mail: thais.trevisan.teixeira@usp.br. Para alguma consideração ou dúvida sobre aspectos éticos dessa pesquisa, entre em contato com o Comitê de Ética em Pesquisa da Escola de Enfermagem da USP, situado no endereço: Av. Dr. Enéas de Carvalho Aguiar, 419 - Cerqueira César - São Paulo/SP; telefone (11) 3061-8858; e-mail: cepee@usp.br.

Caso você concorde participar, rubricar a primeira página e assinar este documento em duas vias, autorizando dessa forma que os dados colhidos sejam utilizados nesta pesquisa. Você receberá uma via e a outra ficará guardada com a pesquisadora.

Esta pesquisa atende todas as especificações da Resolução n. 466, de 12 de dezembro de 2012, do Conselho Nacional de Saúde, que aprova as diretrizes e normas regulamentadoras de pesquisas envolvendo seres humanos.

Itapecerica da Serra, de de

Nome completo da participante

Assinatura da participante

Assinatura da pesquisadora 


\section{APÊNDICE F}

\section{TERMO DE CONSENTIMENTO LIVRE E ESCLARECIDO (Responsável legal por menor 18 anos de idade)}

Eu, Thaís Trevisan Teixeira, obstetriz e aluna do curso de Pós-Graduação nível mestrado da Escola de Enfermagem da Universidade de São Paulo, estou realizando a pesquisa "Ensaio clínico sobre o uso de adesivo cirúrgico no reparo de lacerações perineais de primeiro grau", para saber se o adesivo (ou cola cirúrgica) também é eficaz para a cicatrização das lacerações perineais que podem acontecer no parto normal. Esta pesquisa pretende saber se o uso da cola cirúrgica promove menos dor no períneo, melhor cicatrização e mais satisfação, em comparação com a sutura com fio e agulha.

Você está sendo solicitado a autorizar a participação da menor

convidada a participar da pesquisa, como voluntária, caso ela aceite. Durante o parto, caso ela tenha alguma laceração de primeiro grau (que atinge a pele e/ou a mucosa vaginal) e que precise de sutura, ela será incluída em um dos dois grupos da pesquisa mediante a um sorteio. No grupo da cola cirúrgica, o reparo da laceração será feito com gotas de Epiglu ${ }^{\circledR}$. No grupo de sutura com fio e agulha, será usado o método tradicional, de pontos com Vicryl Rapide ${ }^{\circledR}$. Caso ela tenha outras lacerações mais profundas, de segundo ou terceiro graus, ela não participará desta pesquisa e o reparo da laceração será realizado conforme o padrão da maternidade.

No máximo 2 horas após o reparo da laceração, realizaremos uma entrevista de duração aproximada de 5 minutos para que ela nos relate a intensidade da dor e a sua satisfação quanto ao método de reparo. A região perineal será avaliada e fotografada antes e após o reparo perineal para melhor avaliação do períneo. Essa entrevista ocorrerá também no alojamento conjunto, no primeiro e no segundo dia de internação, com duração aproximada de 5 minutos. Depois da alta hospitalar, entre 10 a 20 dias pós-parto, realizaremos mais uma entrevista, avaliação do períneo e fotografia, com duração aproximada de 5 minutos. Esta etapa será realizada no Pronto Socorro e Maternidade Zoraide Eva das Dores ou na casa dela, como for mais conveniente para ela.

Não haverá custo e nem pagamento pela participação dela. Porém, nos dias em que for solicitada presença dela, além dos dias de internação, está garantido a ela e ao seu acompanhante o ressarcimento de despesas tais como transporte e alimentação, caso refiram necessidade. Haverá indenização para eventuais danos decorrentes da pesquisa, comprovados legalmente.

Participando desta pesquisa ela contribuirá para o avanço do conhecimento sobre a saúde materna e a qualidade do atendimento no parto, beneficiando as mulheres que passarão pela mesma situação. $O$ benefício esperado é que com a cola cirúrgica não seja preciso usar anestesia local para o reparo perineal, que cause menos dor perineal no período pós-parto e maior satisfação com o resultado do reparo.

Os riscos previstos na pesquisa são uma possível reação inflamatória no local do reparo, a separação das beiradas da laceração e alergia ao material utilizado. Existe também algum risco previsto de falha do reparo com a cola e, nesse caso, o reparo será realizado com 
anestesia, fio e agulha. Pode ocorrer algum constrangimento com a fotografia da região perineal, mas nessa fotografia, ela não será identificada, pois seu rosto não aparecerá. Se durante a entrevista, exame ou fotografia ela tiver algum desconforto e constrangimento, será oferecido acolhimento, respeitando o seu desejo de aceitar ou não responder as perguntas, ser examinada e fotografada.

Caso ela tenha alguma reação, independente do uso da cola ou fio cirúrgico, ela terá a garantia de assistência e de cuidados oferecidos pela pesquisadora e por esta maternidade. Ela também terá a garantia de assistência integral e gratuita pelo tempo que for necessário em caso de danos decorrentes direta ou indiretamente da sua participação do estudo.

Vocês têm o direito de receber informações e esclarecimentos de dúvidas em qualquer momento que desejar durante a pesquisa e têm a liberdade para recusar a participar, de retirar seu consentimento ou interromper a participação a qualquer momento, sem acarretar prejuízo no seu atendimento nesta maternidade.

Os resultados da pesquisa serão transformados em trabalhos científicos e apresentados em congressos e revistas da área da saúde. O nome dela não será identificado na divulgação dos resultados da pesquisa, pois as suas respostas e as fotografias serão analisadas em conjunto com as de outros participantes. Os dados e as imagens desta pesquisa serão guardados pela pesquisadora.

Você terá acesso à pesquisadora em qualquer etapa do estudo, que poderá ser encontrada no endereço: Av. Dr. Enéas de Carvalho Aguiar, 419 - Cerqueira César - São Paulo/SP, no telefone (11) 9737-99623, e-mail: thais.trevisan.teixeira@ usp.br. Para alguma consideração ou dúvida sobre aspectos éticos dessa pesquisa, entre em contato com o Comitê de Ética em Pesquisa da Escola de Enfermagem da USP, situado no endereço: Av. Dr. Enéas de Carvalho Aguiar, 419 - Cerqueira César - São Paulo/SP; telefone (11) 3061-8858; e-mail: cepee@usp.br.

Caso você concorde consentir a participação, rubricar a primeira página e assinar este documento em duas vias, autorizando dessa forma que os dados colhidos sejam utilizados nesta pesquisa. Você receberá uma via e a outra ficará guardada com a pesquisadora.

Esta pesquisa atende todas as especificações da Resolução n. 466, de 12 de dezembro de 2012, do Conselho Nacional de Saúde, que aprova as diretrizes e normas regulamentadoras de pesquisas envolvendo seres humanos.

Itapecerica da Serra, de de

Nome completo da participante

Assinatura da participante

Assinatura da pesquisadora 


\section{ANEXO 1}

USP - ESCOLA DE
ENFERMAGEM DA
ENIVERSIDADE DE SÃO

\section{PARECER CONSUBSTANCIADO DO CEP}

\section{DADOS DO PROJETO DE PESQUISA}

\section{Título da Pesquisa: ENSAIO CLÍNICO SOBRE O USO DA COLA ADESIVA CIRÚRGICA NO REPARO DE LACERAÇÕES PERINEAIS DE PRIMEIRO GRAU}

Pesquisador: THAIS TREVISAN TEIXEIRA

Área Temática:

Versão: 3

CAAE: 63981517.0 .0000 .5392

Instituição Proponente: Escola de Enfermagem da Universidade de São Paulo - EEUSP

Patrocinador Principal: Financiamento Próprio

\section{DADOS DO PARECER}

Número do Parecer: 2.026.675

\section{Apresentação do Projeto:}

Trata-se de projeto de mestrado que pretende avaliar o uso de cola adesiva no reparo de lesões perineais decorrentes do parto vaginal. O projeto será desenvolvido no Centro de Parto Normal (CPN) do Pronto Socorro e Maternidade Municipal Zoraide Eva das Dores, Itapecerica da Serra, SP, e em unidades básicas de saúde (UBS) e domicílio das mulheres. Será realizado estudo piloto com 20 mulheres, distribuídas nos grupos experimental $(n=10)$ e controle $(n=10)$, para estabelecer o tamanho da amostra. A alocação nos grupos será aleatorizada, o grupo experimental utilizará reparo com cola adesiva cirúrgica Epiglu® (etil-2cianoacrilato). O produto foi autorizado pela Anvisa sob o registro 8016417007. Grupo controle: reparo com fio poliglactina 910 de rápida absorção (Vicryl Rapide®). Serão avaliados os seguintes desfechos: dor perineal, processo de cicatrização, satisfação e tempo dispendido pelo profissional. As mulheres que atenderem aos seguintes critérios de elegibilidade serão convidadas a participar do estudo após a internação no CPN: Ter até 6 centímetros de dilatação cervical; Não fazer uso de substâncias esteroides;Não apresentar leucorréia ou qualquer sinal de infecção no local de reparo;Sem diagnóstico de diabetes mellitus;Sem histórico de alergia à cola cirúrgica ou ao formaldeído;Sem dificuldade no entendimento do idioma português ou na comunicação;Aceitar ser submetida aos métodos de reparo perineal com cola cirúrgica ou fio de sutura. São critérios de inclusão: Ter parto normal

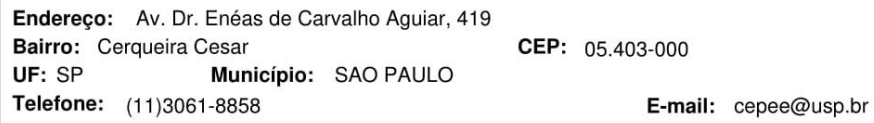




USP - ESCOLA DE
ENFERMAGEM DA
UNIVERSIDADE DE SÃO

Continuação do Parecer: 2.026.675

com laceração de primeiro grau com indicação de sutura, segundo critério do profissional responsável pelo atendimento; Não ter episiotomia ou laceração de segundo, terceiro ou quarto graus; Não ter fisometria;Não ter varizes vulvares; e critérios de exclusão: Complicações decorrentes do parto ou pós-parto que exijam transferência hospitalar da mulher para um hospital de alta complexidade. No grupo estudo será utilizada a cola adesiva e no grupo controle será realizada sutura cirúrgica. Antes e após a intervenção, será tirada uma fotografia para registrar a laceração perineal e o reparo realizado. As fotos serão utilizadas com a finalidade de documentação do estudo. Os dados serão obtidos mediante consulta ao prontuário, entrevista com a mulher e exame perineal. A avaliação pós-parto será realizada em 12-24 horas, 36-48 horas e 10-20 dias.

\section{Objetivo da Pesquisa:}

Objetivo geral: Avaliar a efetividade da cola adesiva cirúrgica no reparo das lacerações perineais de primeiro grau decorrentes do parto normal.

Objetivos específicos: Comparar o tempo de reparo das lacerações perineais de primeiro grau com cola adesiva cirúrgica e sutura com fio; Comparar a intensidade e a ocorrência da dor perineal em mulheres submetidas ao reparo com cola adesiva cirúrgica e sutura com fio; Comparar o processo de cicatrização das lacerações perineais de primeiro grau com a cola adesiva cirúrgica e a sutura com fio; Comparar a satisfação da mulher com o uso da cola adesiva cirúrgica e da sutura com fio.

\section{Avaliação dos Riscos e Benefícios:}

Riscos: Possível reação inflamatória no local do reparo, a separação das beiradas da laceração e alergia ao material utilizado.

Benefícios: $O$ benefício esperado é que com a cola cirúrgica não seja preciso usar anestesia local para o reparo perineal, que cause menos dor perineal no período pós-parto e maior satisfação com o resultado do reparo.

\section{Comentários e Considerações sobre a Pesquisa:}

Trata-se de estudo piloto que pretende avaliar o uso de cola cirúrgica na reparação perineal pós-parto, em casos de lesão perineal de $1^{\circ}$ grau. Dez participantes serão submetidas à reparação com cola cirúrgica e 10 com sutura cirúrgica tradicional.

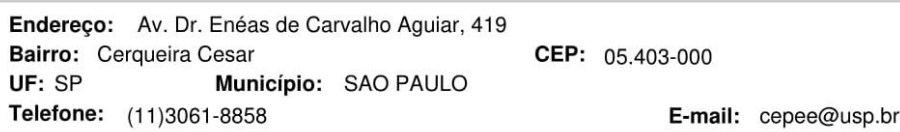




\section{USP - ESCOLA DE
ENFERMAGEM DA
ENFERMAGEM $\quad \begin{aligned} & \text { Plotoforma } \\ & \text { UNIVERSIDADE DE SÃO }\end{aligned}$}

Continuação do Parecer: 2.026.675

O projeto é bem apresentado e claro, com todas etapas descritas, bem como os procedimentos propostos. Considerando-se que os pesquisadores não informam o tamanho definitivo da amostra, pois dependem dos resultados do estudo piloto, é necessário apresentar emenda informando o tamanho amostral definitivo, quando este for conhecido.

\section{Considerações sobre os Termos de apresentação obrigatória:}

Os termos de consentimento / assentimento foram corrigidos e estão adequados. O cronograma foi ajustado e os documentos obrigatórios não apresentam pendências éticas.

\section{Recomendações:}

Não há.

Conclusões ou Pendências e Lista de Inadequações:

Aprovado.

Considerações Finais a critério do CEP:

- Este CEP informa a necessidade de registro de resultados parciais e finais na Plataforma Brasil

- Este parecer não substitui a autorização da instituição coparticipante, antes do início da coleta de dados.

Este parecer foi elaborado baseado nos documentos abaixo relacionados:

\begin{tabular}{|l|l|c|l|c|}
\hline \multicolumn{1}{|c|}{ Tipo Documento } & \multicolumn{1}{|c|}{ Arquivo } & Postagem & \multicolumn{1}{c|}{ Autor } & Situação \\
\hline $\begin{array}{l}\text { Informações Básicas } \\
\text { do Projeto }\end{array}$ & $\begin{array}{l}\text { PB_INFORMAÇOEESBÁSICAS_DO_P } \\
\text { ROJETO 856686.pdf }\end{array}$ & $\begin{array}{c}29 / 03 / 2017 \\
20: 13: 17\end{array}$ & Aceito \\
\hline $\begin{array}{l}\text { Projeto Detalhado / } \\
\text { Brochura }\end{array}$ & $\begin{array}{l}\text { PROJETO_THAIS_TREVISAN_terceira } \\
\text { Investigador }\end{array}$ & $\begin{array}{c}29 / 03 / 2017 \\
20: 12: 53\end{array}$ & $\begin{array}{l}\text { THAIS TREVISAN } \\
\text { TEIXEIRA }\end{array}$ & Aceito \\
\hline TCLE / Termos de & TERMO_DE_ASSENTIMENTO_LIVRE_ & $29 / 03 / 2017$ & THAIS TREVISAN & Aceito \\
Assentimento / & E_ESCLARECIDO_terceira_versao.doc & $20: 08: 57$ & TEIXEIRA & \\
Justificativa de & X & & & \\
Ausência & & & & Aceito \\
\hline TCLE / Termos de & TERMO_DE_CONSENTIMENTO_LIVR & $29 / 03 / 2017$ & THAIS TREVISAN & \\
\hline
\end{tabular}

\footnotetext{
Endereço: Av. Dr. Enéas de Carvalho Aguiar, 419

Bairro: Cerqueira Cesar

CEP: $05.403-000$

UF: SP

Município: SAO PAULO

Telefone: (11)3061-8858

E-mail: cepee@usp.br
} 


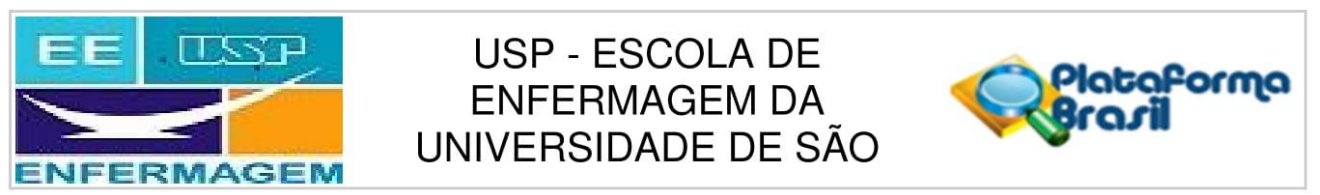

Continuação do Parecer: 2.026.675

\begin{tabular}{|c|c|c|c|c|}
\hline $\begin{array}{l}\text { Assentimento / } \\
\text { Justificativa de } \\
\text { Ausência }\end{array}$ & $\begin{array}{l}\text { E_ESCLARECIDO_RESPONSAVEL_LE } \\
\text { GAL_terceira_versao.docx }\end{array}$ & $20: 08: 35$ & TEIXEIRA & Aceito \\
\hline $\begin{array}{l}\text { TCLE / Termos de } \\
\text { Assentimento / } \\
\text { Justificativa de } \\
\text { Ausência }\end{array}$ & $\begin{array}{l}\text { TERMO_DE_CONSENTIMENTO_LIVR } \\
\text { E_E_ESCLARECIDO_MAIORIDADE_te } \\
\text { rceira_versao.docx }\end{array}$ & $\begin{array}{l}29 / 03 / 2017 \\
20: 08: 07\end{array}$ & $\begin{array}{l}\text { THAIS TREVISAN } \\
\text { TEIXEIRA }\end{array}$ & Aceito \\
\hline Folha de Rosto & folha_de_rosto.pdf & $\begin{array}{c}23 / 01 / 2017 \\
14: 50: 51\end{array}$ & $\begin{array}{l}\text { THAIS TREVISAN } \\
\text { TEIXEIRA }\end{array}$ & Aceito \\
\hline
\end{tabular}

Situação do Parecer:

Aprovado

Necessita Apreciação da CONEP:

Não

SAO PAULO, 22 de Abril de 2017

\begin{tabular}{c}
\hline Assinado por: \\
Marcelo José dos Santos \\
(Coordenador)
\end{tabular}

(Coordenador)

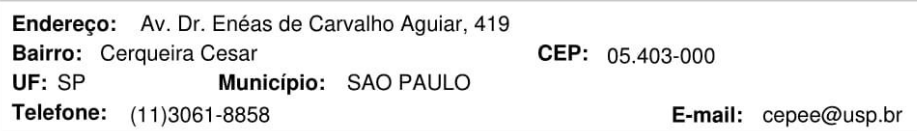




\section{ANEXO 2}
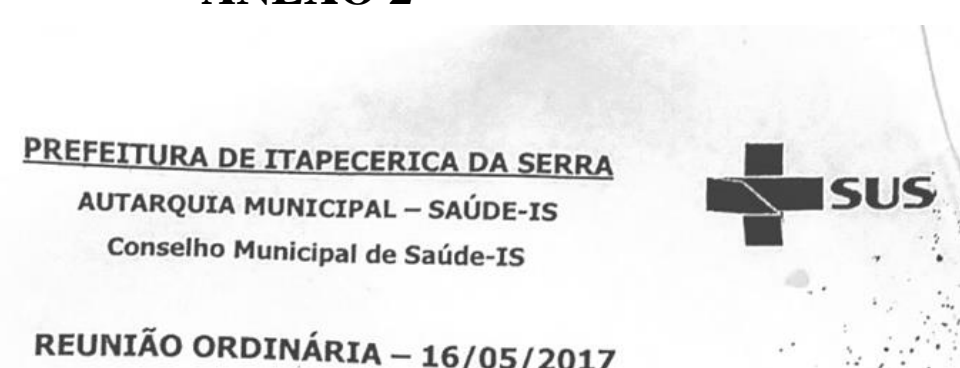

Em reunião ordinária do Conselho Municipal de Saúde de Itapecerica da Serra, realizada em 16 de maio de 2017, a aluna da Escola de Enfermagem da Universidade de São Paulo Thaís Trevisan Teixeira, apresentou o Projeto de Pesquisa com o Tema: "ENSAIO CLÍNICO SOBRE O USO DE COLA ADESIVA CIRURGICA NO REPARO DE LACERAÇÕES PERINEIAS DE PRIMEIRO GRAU", que foi APROVADO pelos Conselheiros que abaixo assinam.

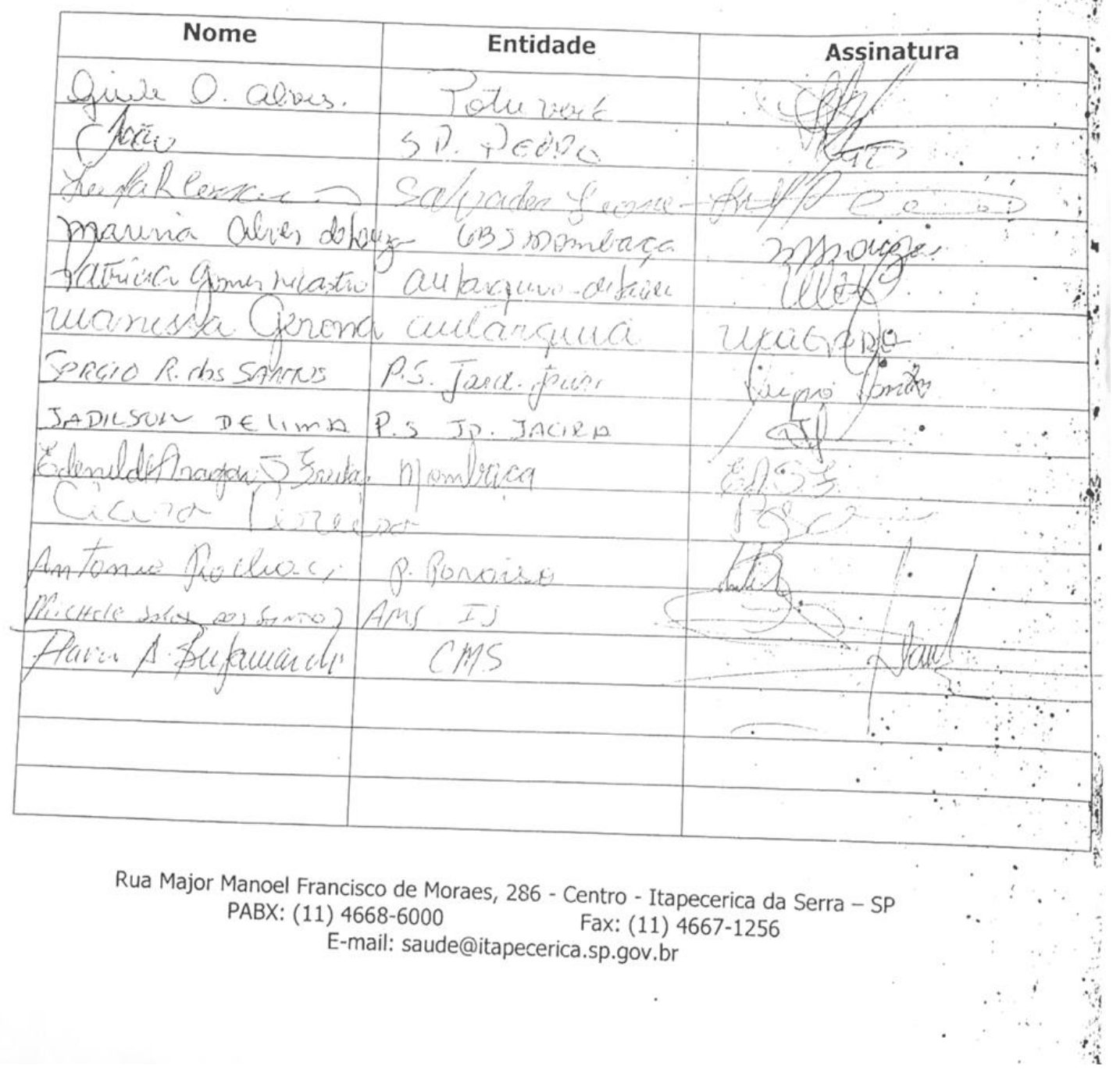

